Portland State University

PDXScholar

Environmental Science and Management

Professional Master's Project Reports

Summer 2016

\title{
Clear Creek Estuary Restoration: Establishing an Ecological Monitoring Program and Baseline Conditions
}

Christine Butler-Minor

Portland State University

Follow this and additional works at: https://pdxscholar.library.pdx.edu/mem_gradprojects

Part of the Environmental Indicators and Impact Assessment Commons, Environmental Monitoring Commons, and the Water Resource Management Commons Let us know how access to this document benefits you.

\section{Recommended Citation}

Butler-Minor, Christine, "Clear Creek Estuary Restoration: Establishing an Ecological Monitoring Program and Baseline Conditions" (2016). Environmental Science and Management Professional Master's Project Reports. 52.

https://pdxscholar.library.pdx.edu/mem_gradprojects/52

https://doi.org/10.15760/mem.54

This Project is brought to you for free and open access. It has been accepted for inclusion in Environmental Science and Management Professional Master's Project Reports by an authorized administrator of PDXScholar. Please contact us if we can make this document more accessible: pdxscholar@pdx.edu. 


\section{Clear Creek Estuary Restoration: Establishing an Ecological Monitoring Program and Baseline Conditions}

\section{Christine Butler-Minor}

June 28, 2016

\section{Masters of Environmental Management Project}

Monitoring habitat conditions in the Clear Creek Estuary before the completion of the Bucklin Hill Bridge Project is a critical part of this ecosystem restoration planning and execution. The Clear Creek Trail Alliance (CCTA) is working with local partners to monitor the effects of the estuary restoration. In a wider effort to characterize salmonid habitat suitability of the estuary prior to the bridge replacement, CCTA would like to gather data related to water quality, beach/bank elevations, vegetation in the vicinity, and invertebrate diversity in the estuary. The development and implementation of this Clear Creek Estuary monitoring project provides an opportunity for students and local citizens to expand their knowledge of salmon habitat needs and learn about the benefits to salmon afforded through estuary restorations. These reliable, verifiable, and accurate data will be contributed to the State's Marine Water Quality Monitoring Program plus shared with citizens of Kitsap County and other parties interested in gaining knowledge concerning the effectiveness of the restoration project. Comparison of data collected prior to and then following construction will aid in understanding the successful restoration features of the project and assist in determining if adaptations are needed in the ongoing management of this revitalized ecosystem.

Presented to:

Joseph Maser, PhD.

Eugene Foster, PhD.

Mary Earl, Director of Clear Creek Trail Alliance 


\section{Contents}

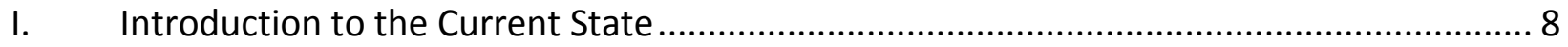

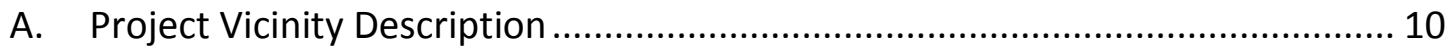

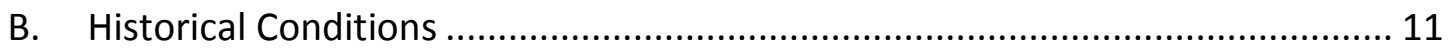

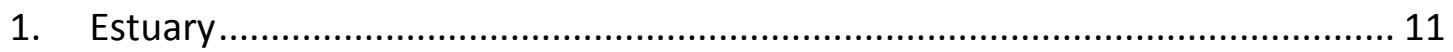

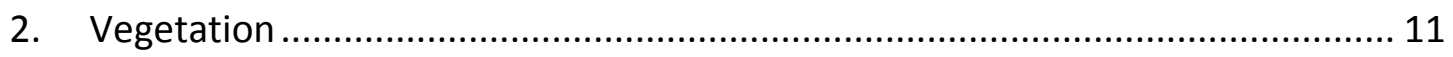

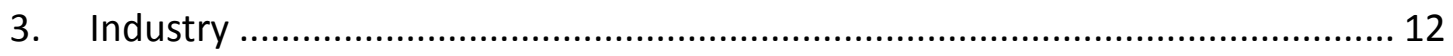

C. Previous Studies and Contaminants of Concern .............................................. 13

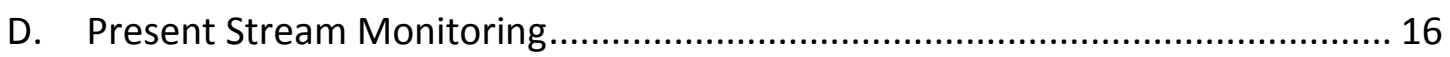

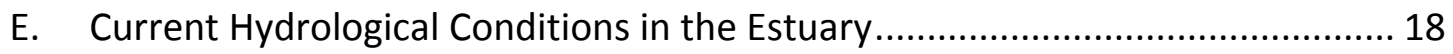

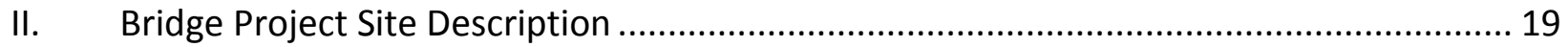

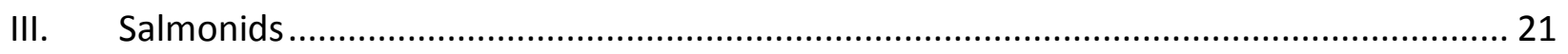

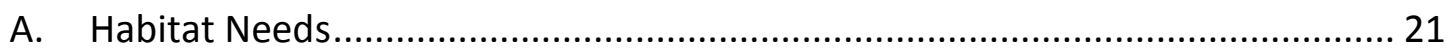

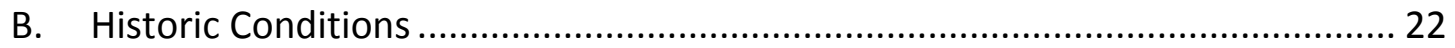

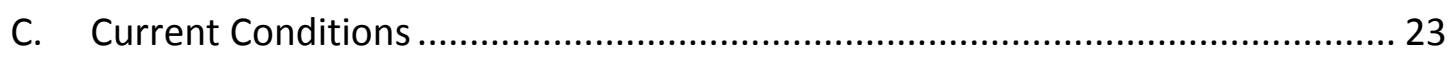

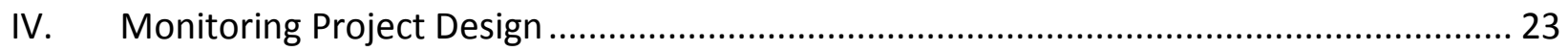

V. Community Partner Needs ...................................................................................... 23

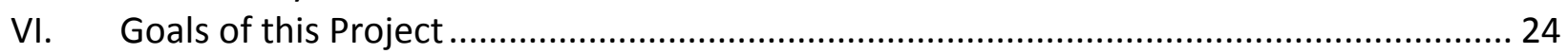

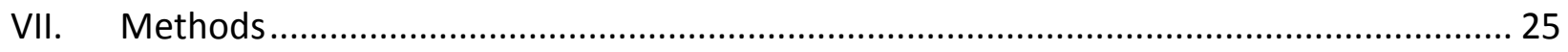

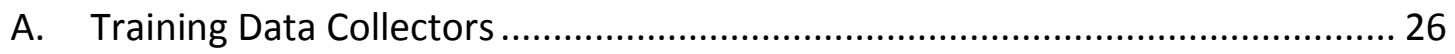

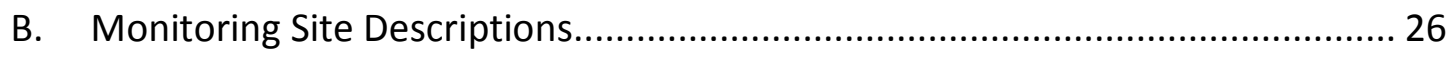

C. Parameters, Collection and Processing Procedures ....................................... 30

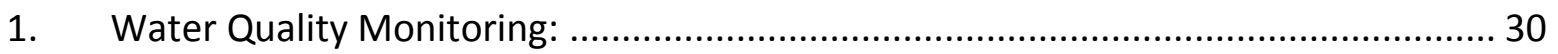

2. Sediment Characteristics and Profiles .............................................................. 33

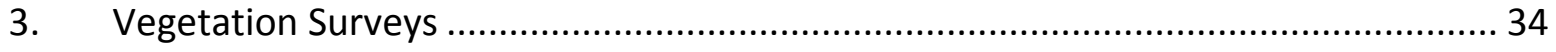

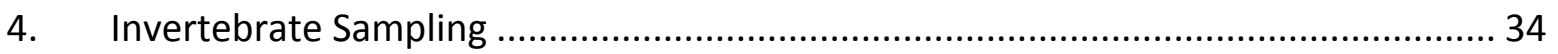

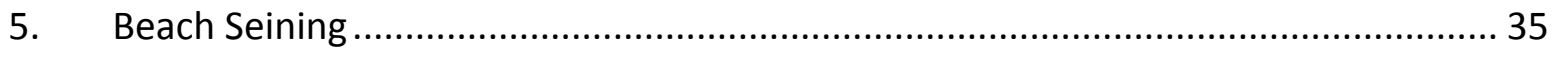

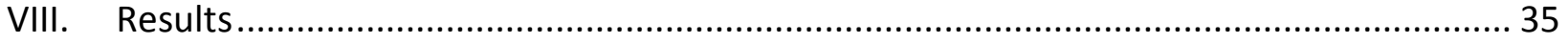

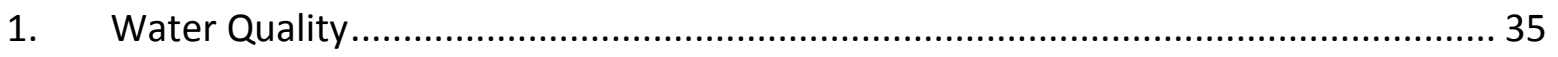

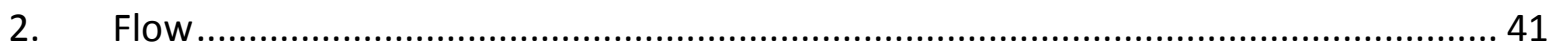

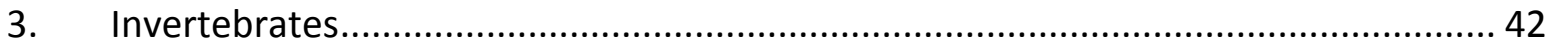

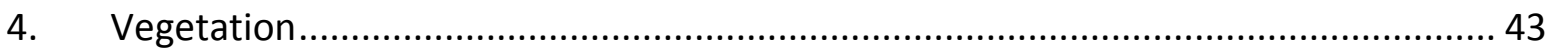

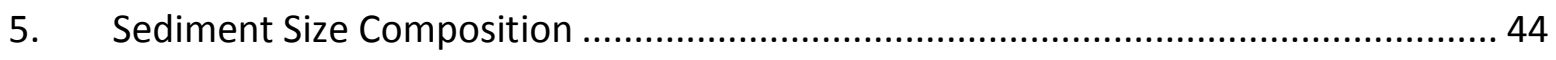

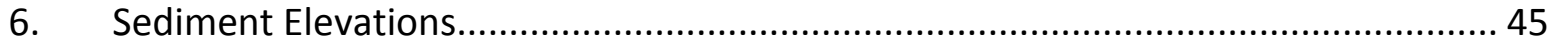

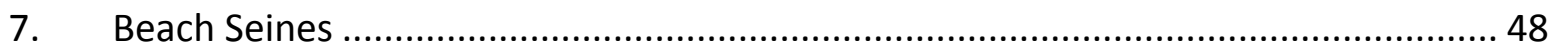

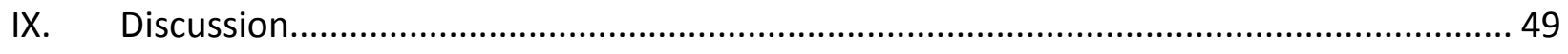

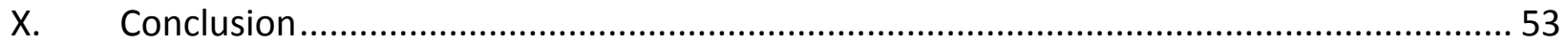

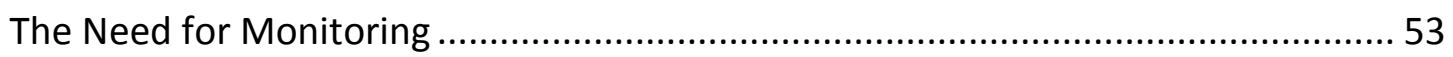

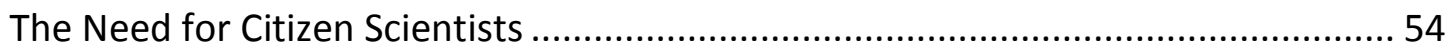

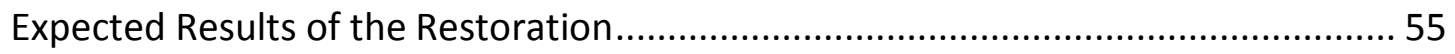

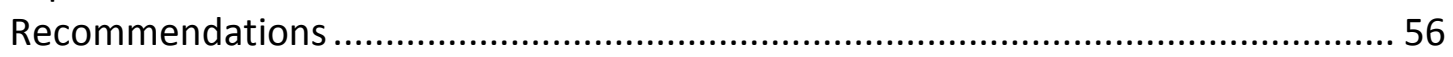

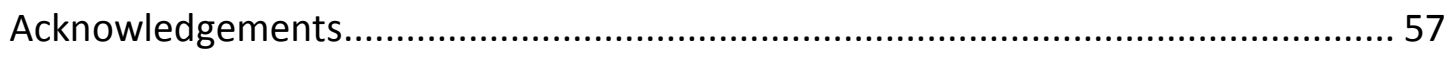

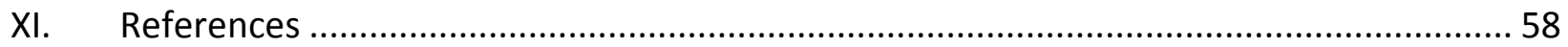




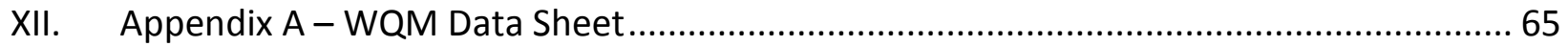

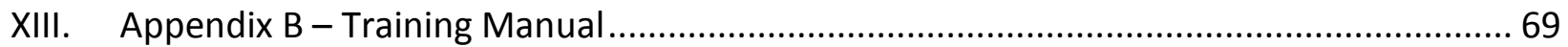

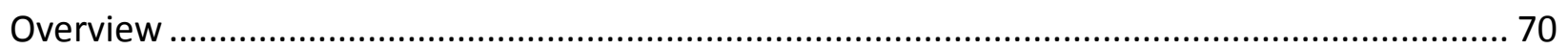

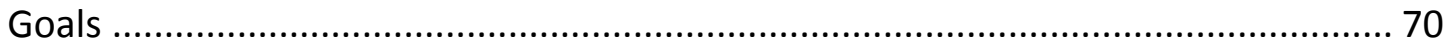

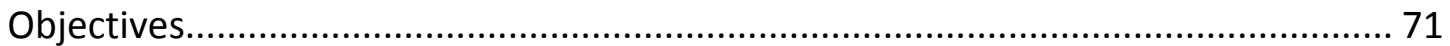

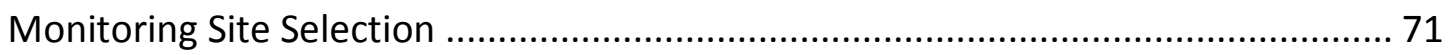

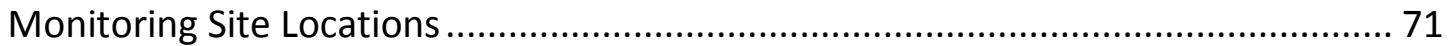

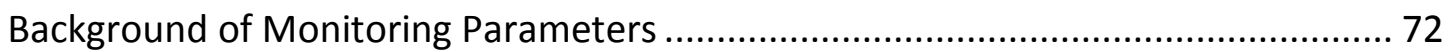

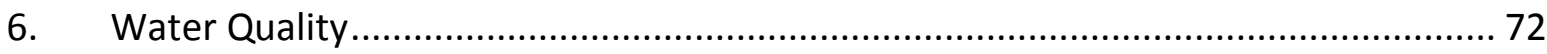

7. Invertebrates and other nearshore inhabitants ................................................ 74

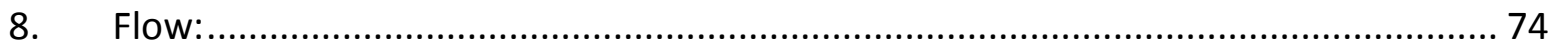

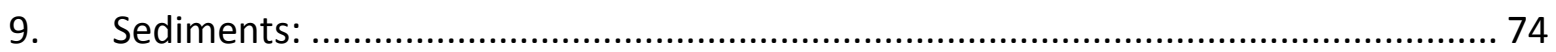

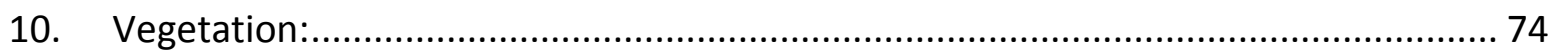

Field Sampling Procedures and Analysis Methods ............................................................. 75

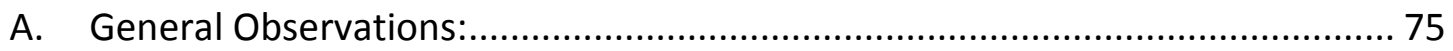

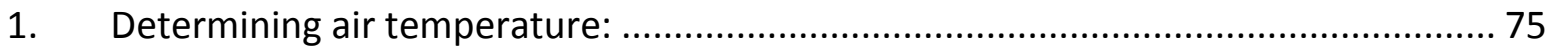

2. Estimate wind speed:................................................................................. 76

3. Measure Wind Direction:..................................................................................... 76

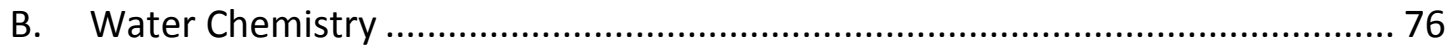

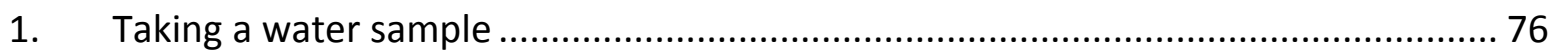

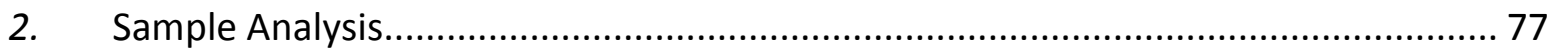

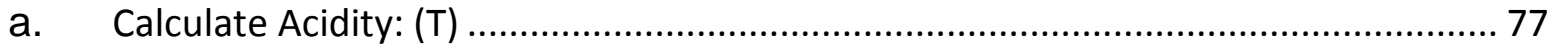

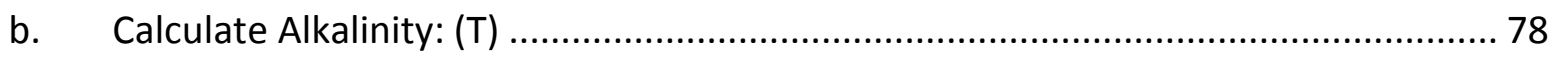

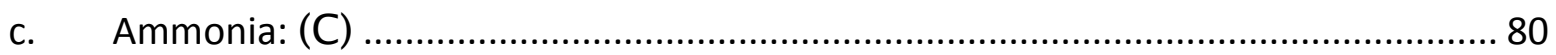

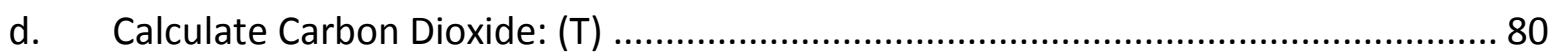

a. Conductivity aka Specific Electrical Conductivity (EC): (D) ................................. 81

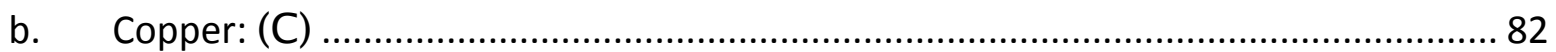

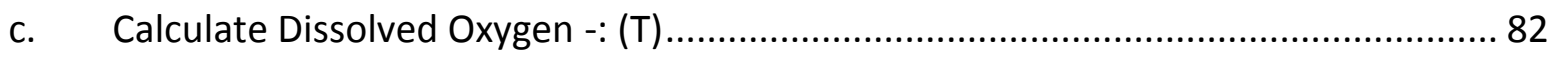

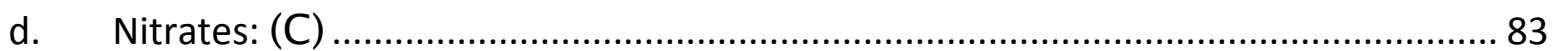

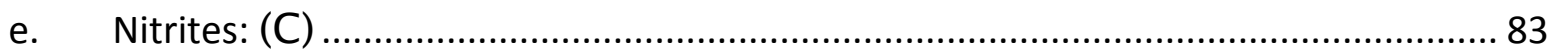

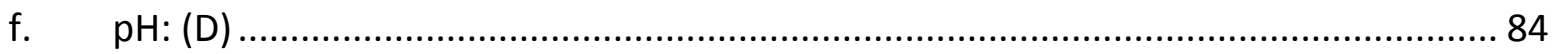

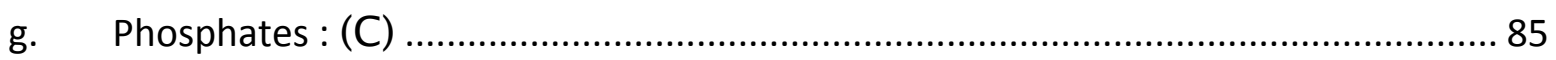

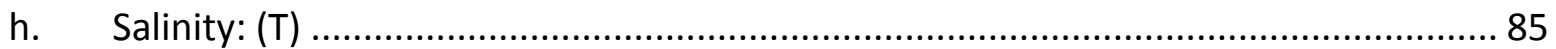

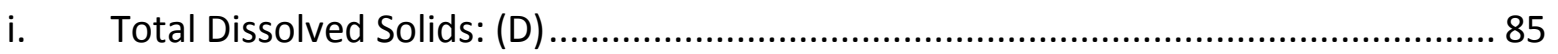

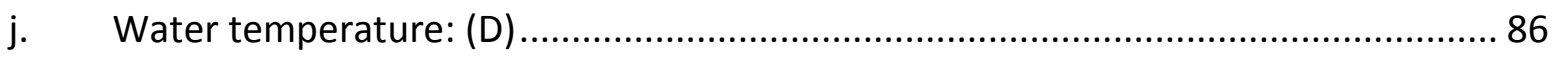

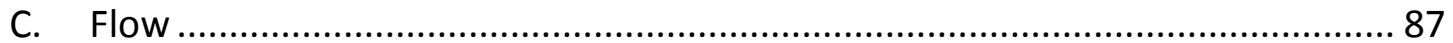

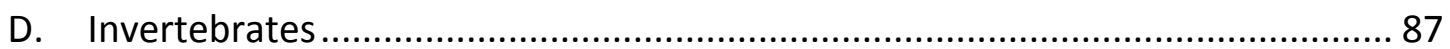

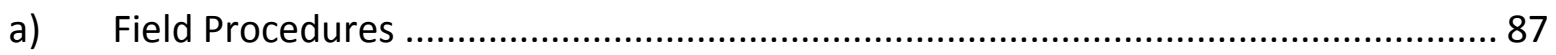

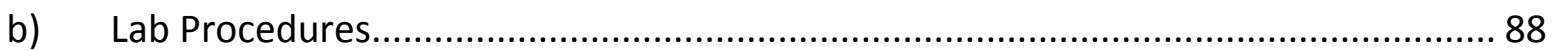

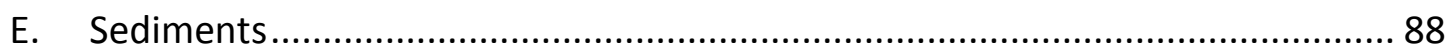

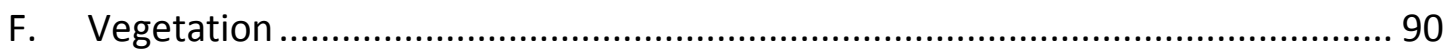

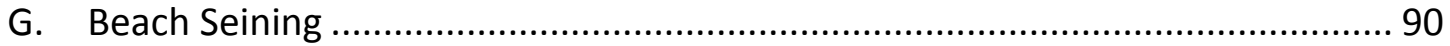


XIV. Appendix C - Kitsap Health Department Conventional WQM Data .............................. 91

XV. Appendix D - Tested Parameters without Washington State Water Quality Standards .. 92

XVI. Appendix E-2015 Vegetation Survey................................................................. 95

XVII. Appendix F - Water Quality Standards for Metals in Surface Waters ........................... 98

\section{List of Tables}

Table 1: Kitsap County Health Department Saltwater Fecal Coliform (FC) Bacteria sampling results submitted to Washington State Department of Ecology (DOE) over the period of 20042015. Adapted from Kitsap County Health Dyes Inlet Final Report, Kitsap Co. Health Department, and DOE EIMData....

Table 2 Kitsap County Health Department Freshwater Fecal Coliform (FC) Bacteria sampling results submitted to Washington State Department of Ecology (DOE) over the period of 20042015. Adapted from Kitsap County Health Dyes Inlet Final Report and DOE EIMData

Table 3: Beneficial Use categories for dissolved oxygen criteria in estuaries. Adapted from WAC 173-201A-200(1)(d) - freshwater and WAC 173-201A-210(1)(d)- marine 15

Table 4: Washington State Water Quality Assessment for Clear Creek and North Dyes Inlet. WA Department of Ecology. 16

Table 5: Washington State Water Quality Standards related to $\mathrm{pH}$ for Aquatic Life Uses.

Table 6: Washington State Water Quality Standards related to temperature requirements for Aquatic Life Uses....

Table 7: Water quality parameters collected near Clear Creek Estuary from October 2005 through September 2015.

Table 8: Stream Benthos Monitoring 2010-2013 results. Adapted from Kitsap County Dept of Public Works - Stormwater Division (Jul 2014).

Table 9: Salmon species escapements in East Kitsap County Streams. Adapted from DWFWRIA15, 1971

Table 10: Salmon species smolts captured in 2002 seining at Clear Creek Estuary. Adapted from Dyes Inlet Estuary Study: Chico, Clear and Barker Estuaries December 2003 23

Table 11: The Monitoring Schedule of Clear Creek Estuary .................................................. 30

Table 12: Water Quality Monitoring Parameters of Clear Creek Estuary ............................... 31 
Table 13 Invertebrate sampling results.

Table 14: Vegetation survey results.

Table 15: Sediment Size by Site and Location for Full Transit Profile 44

Table 16: Sediment Size by Site and Location for In-Stream/Wetted Segments of Transects.... 45

Table 17: 2014 Beach Seine results. 48

\section{Figures}

Figure 1 The Clear Creek Estuary. Courtesy of Scripps Media, Inc.... 8

Figure 2: West and North forks of the Clear Creek in the Clear Creek Watershed converge into the estuary and bridge area. Courtesy of Kitsap County Public Works.

Figure 3: Sneebeck Mill circa 1958. Courtesty of Kitsap County Historical Society ...... 12

Figure 4: Smith Farm formerly known as "Tide's End". Courtesy of Stacy Bargerstock, 1987 ..... 12

Figure 5: Transition towards urbanization in the Clear Creek Watershed. Adapted from Bucklin Hill Bridge Replacement \& Estuary Enhancement Project, Kitsap County 2014 13

Figure 6: Erosion on the marine side of the Bucklin Hill Bridge culverts. June 2015 19

Figure 7: Sediment buildup as Clear Creek approaches the Bucklin Hill Bridge culverts.

September 2014 19

Figure 8: Existing Bucklin Bridge. May 2014 Courtesy of Google Earth 20

Figure 9: Artistic rendition of new four lane open span bridge with two creek channels. Courtesy of Kitsap County Public Works: Bridge Illustrations 20

Figure 10: Pacific Salmon Life Cycle: Adapted from "The fascinating life cycle of an Alaska salmon from birth to spawning". 21

Figure 11: Monitoring Sites on the Clear Creek Estuary. Courtesy of Google Earth. 27

Figure 13: Data Form for Calculating Flow. Modified from EPA Volunteer Stream Monitoring: A Methods Manual, Data Form for Calculating Flow 32

Figure 14: Salinity in parts per thousand (ppt). 36 
Figure 15: Collected $\mathrm{pH}$ values at Sites 1-4.......

Figure 16: Site 1 Dissolved Oxygen (DO) versus Washington marine water quality standards... 38

Figure 17: Site 2 Dissolved Oxygen (DO) versus Washington marine water quality standards .. 38

Figure 18: Site 3 Dissolved Oxygen concentrations versus Washington marine water quality standards.

Figure 19: Site 4 Measured dissolved oxygen (DO) versus Washington fresh water quality standards

Figure 20: Comparison of Measured Temperatures to Washington State Water Quality Standards for Marine water at Site1..

Figure 21: Comparison of Measured Temperatures to Washington State Water Quality Standards for Marine water at Site2.

Figure 22: Comparison of Measured Temperatures to Washington State Water Quality Standards for Marine water at Site3. 40

Figure 23: Comparison of Measured Temperatures to Washington State Water Quality Standards for Freshwater water at Site4.

Figure 24: 2014-2015 measured flows in Clear Creek Estuary at Monitoring sites and KPUD CC mainstem telemetric gauge.

Figure 25: Site 1 Elevation Profile..... 46

Figure 26: Site 2 Elevation Profile.

Figure 27: Site 3 Elevation Profile..... 47

Figure 28: Site 4 Elevation Profile. 47 


\section{Introduction to the Current State}

Washington State's Central Puget

Sound region is home to nearly 3 million people, in an area experiencing continued population growth (Puget sound Regional Council [PSRC], 2015). Located south of the San Juan Islands as well as west of the Cascade Range and east of the Olympic Mountains, the glacially formed Puget Sound Lowlands contain numerous small streams that spill out into scenic coastlines, rich in aquatic resources [figure 1]. The region has supported indigenous populations with salmon and shellfish for at least the past two millennia (Washington State Department of Ecology [DOE], 2009, Cultural Resources Consultants, Inc

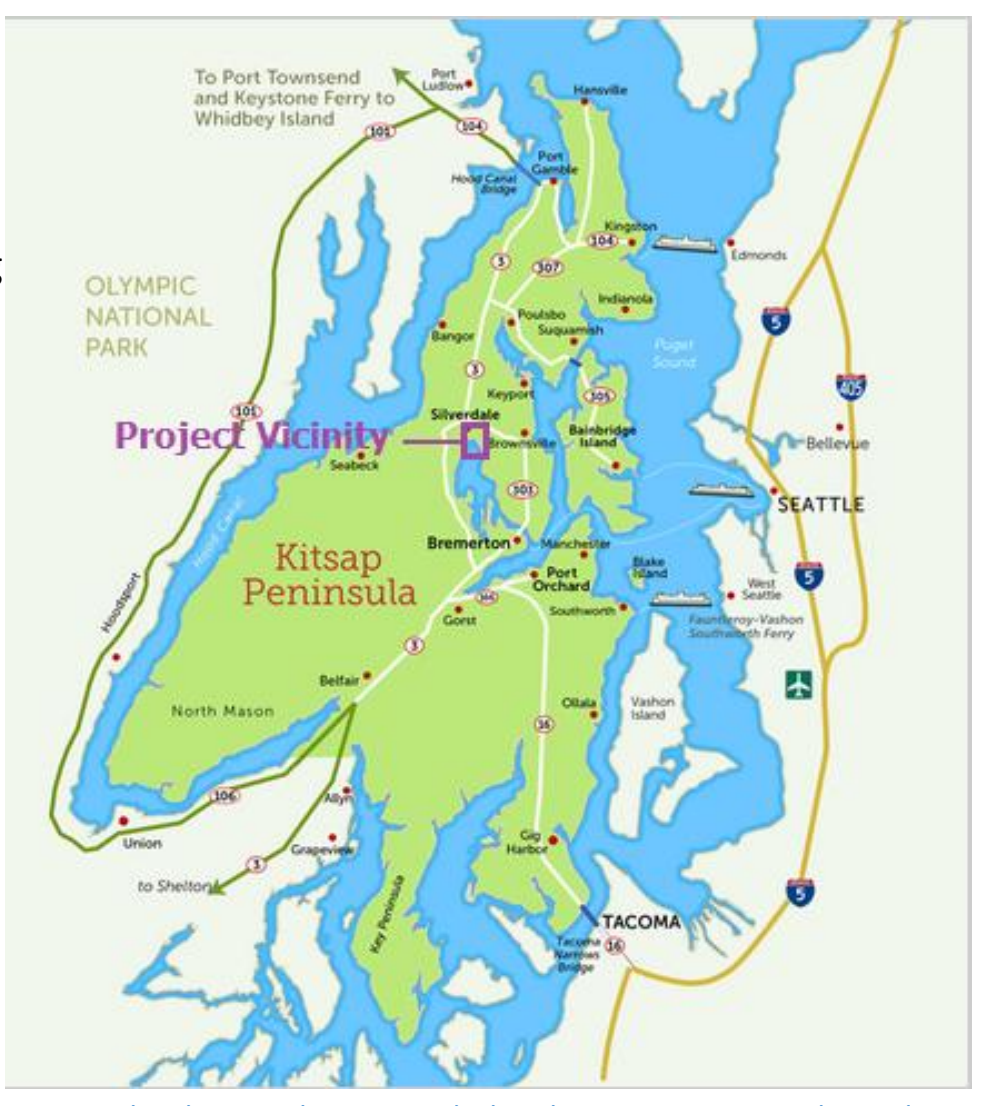

Figure 1 The Clear Creek Estuary, which is the project vicinity, is located on the northwestern shore of Dyes Inlet and in the unincorporated township of [CRC], 2013). However, many changes Silverdale, WA. Courtesy of Scripps Media, Inc

in the appearance and functions of the ecosystems have occurred in these lowland watersheds over the past two centuries. Dramatic population increases in the past two centuries, has transformed the regional environment from practically pristine wilderness to a largely urbanized landscape. Streams have been channelized and piped for agricultural purposes and to mitigate flooding. Over $30 \%$ of the shoreline has been altered, especially by the installation of bulkheads (Puget Sound Partnership [PSP], 2009). These sea walls allow development close to the water's edge, facilitating materials production and transportation as well as panoramic views for residential and commercial properties, such as hotels and resorts.

Not all of the changes are beneficial, even to human inhabitants. As land use is converted from undeveloped to an industrial or residential purpose, frequently large amounts of native vegetation is lost and the porous soils altered to impervious pavements. This conversion of porous soils to impervious pavement can have critical implications for water quality by reducing precipitation infiltration into soils and increasing stormwater water runoff over hardened surfaces. This increased runoff can artificially increase the rate of flow in a stream over a short timeframe, similar to flash flooding events. Thus stormwater runoff surges (event flows) into streams create a condition also known as "flashiness." The "Urban Stream Syndrome [USS]" occurs when flashy hydrologic events are coupled with excess nutrient and pollutant loads 
(Meyer et al., 2005). USS can lead to severe declines in the productive functionality of terrestrial and aquatic environments in addition to water quality impairments.

Urban stormwater is a complex mixture of rain (precipitation) and various surface deposits. As it travels it often collects landscaping fertilizers and compounds originating from vehicles such as metal shavings and polycyclic aromatic hydrocarbons (PAHs). The addition of these types of contaminants reduces water quality. Water quality can be described as the appropriate interaction of the biological, physical, and chemical properties for a beneficial use, such as a drinking water source or habitat for a desirable species (Dersing, 2009).

Anthropogenic impacts, such as declining biogeochemical conditions in the desirable characteristics of air and water, disruption to ecological cycles, and losses of biodiversity due to habitat degradation are factors of concern for many citizens and scientists. In the Puget Sound region the affects of some land conversion has led to rapid declines shellfish and salmon fisheries (Puget Sound Nearshore Ecosystem Restoration Project [PSNERP], 2014). In response to the conditions of Puget Sound, the governor and legislature of Washington State created the Puget Sound Partnership (PSP) in 2007. This coalition of lawmakers, scientists, and citizens was formed in an effort to repair and avoid future damage to the natural resources of the Puget Sound (PSP, 2009).

Watershed alterations in the Puget Sound region are not limited to large cities such as Seattle or Tacoma. Development and industrialization have modified ecosystems on the western side of the Puget Sound as well. Kitsap County is a large peninsula surrounded by Hood Canal to the west and Puget Sound to the east. It is situated due west of King County. The population of Kitsap County is growing on an average of $0.6 \%$ annually (Puget Sound Regional Council [PSRC], 2015). Urbanization is closely tied to population growth, which is occurring throughout the county; especially in unincorporated sections. As its population increases, this County is also experiencing the negative effects of urbanization, such as degraded water quality from stormwater runoff and overloaded septic systems. This is a significant issue for the local Kitsap area and Puget Sound region, as nearly half of central and south Puget Sound nearshore habitat is located on the east side of the Kitsap Peninsula (PSP, 2009).

Increased housing development occurs with population growth. In more rural areas, new residential housing changes the landscape from forested to paved over sediments. This change adds to stormwater volume and can impact septic systems. Septic systems rely on soil infiltration and microbial activity to filter harmful compounds from the waste water. Precipitation volumes that exceed the absorption capacity of soils (saturated conditions) result in untreated waste water (EPA-WWT, 1980). Older homes with septic system treatment for waste water, especially those located at lower elevations, can become less efficient and lead to poor water quality in nearby water bodies. Over the past several decades, Kitsap County's Health Department has partnered with various organizations to fund programs that assist 
residents to reduce septic seepage into nearby water bodies. Current offerings include the Craft 3 Septic Loan Program and the USDA's Section 504 Home Repair program_(Kitsap Public Health District [KPHD], 2013).

Outdated or overloaded infrastructure, which was originally designed to treat smaller volumes of stormwater before it enters nearby water bodies, can negatively affect the suitability of salmon habitat. Recent literature implicates unfiltered stormwater in Coho pre-spawning mortality (Spromberg, 2015).

In an effort to improve stormwater management and simultaneously reverse impairments to ecological functions, several stream restoration activities are occurring within Kitsap County watersheds. According to Kitsap County Public Works the various stormwater management projects being undertaken include upgrades to stormwater ponds, community retrofits of aging infrastructure with "green" stormwater systems, plus stream restoration and watershed enhancements that improve water quality and fish habitat (Kitsap County Public Works [KCPW], 2014).

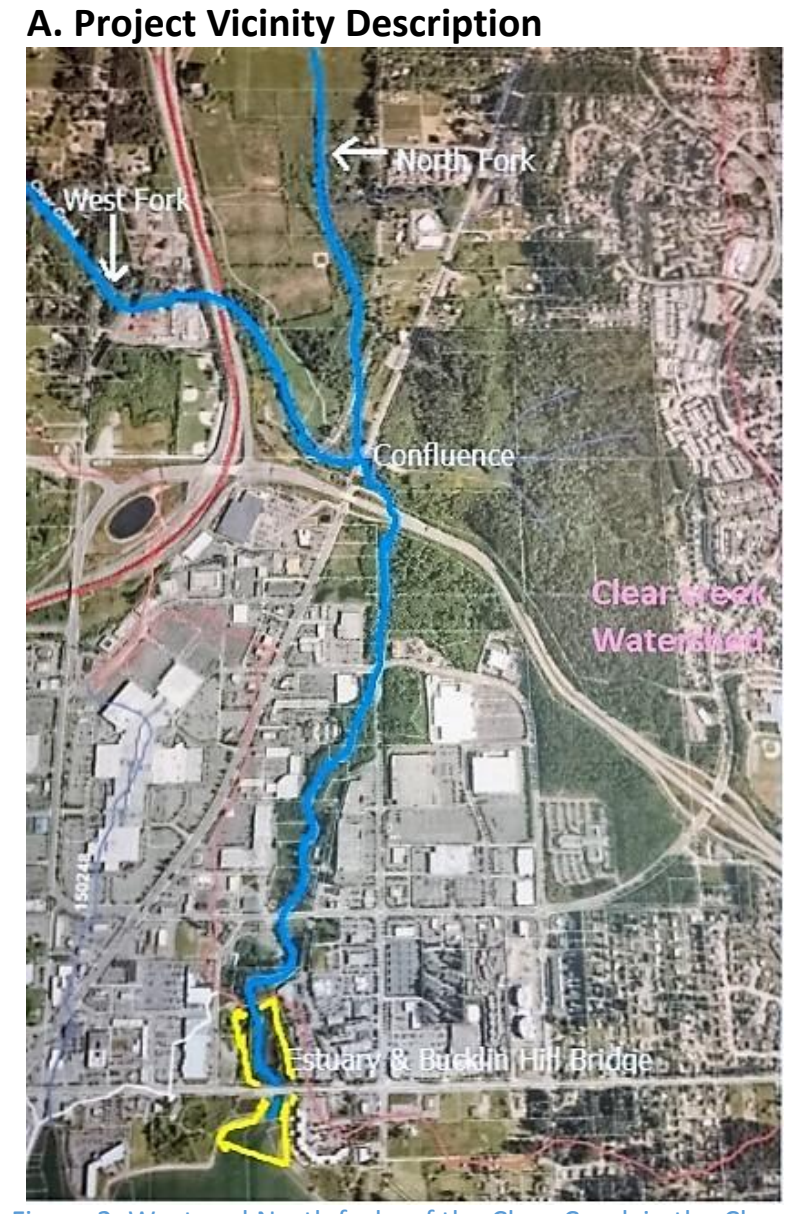

Figure 2: West and North forks of the Clear Creek in the Clear Creek Watershed converge into the estuary and bridge area. Yellow box is project area. (Courtesy of Kitsap Co. Dept of Public Works, Surface and Stormwater)
One of the watersheds undergoing restoration activities is the Clear Creek Watershed (Figure 2). This watershed is located in an urbanizing area of Central Kitsap County. It lies within the western Hemlock Zone (Tsuga heterophylla) of the Puget Sound Lowlands which were scoured 15,000 years ago by the Vashon Stade lobe of the Frasier Glaciations. This glacial lobe deposited Kapowsin gravelly loams and Tacoma silt loam which have become a permeable subsurface over a slightly permeable compressed layer of cemented hardpan with a perched water table ( $\underline{\text { CRC, 2013). }}$.

The main drainage of this watershed is via the convergence of the west and north forks of Clear Creek [figure 2]. Clear Creek is a major low elevation perennial type $\mathrm{S}$ stream (shoreline of the State of Washington). The north fork is spring fed near NW Mountain View Rd in Poulsbo, WA. It then flows south for roughly two miles until it joins the west fork. 
The west fork flows eastward from a hilltop lake on Bangor Naval Base, near the Hood Canal, for approximately four miles. The main stem is result of the merger of the north and west forks. The main stem of the creek flow south for another 3 miles then joins the Clear Creek estuary. The estuary covers an estimated 6.3 acre area situated at the north end of Dyes Inlet.

\section{B. Historical Conditions}

\section{Estuary}

At the northern end of Dyes Inlet is an unincorporated township known as Silverdale, Washington (CCFR, 2014; Otak - BA, 2013; Otak - WA, 2013). Clear Creek flows into the north eastern edge of the Inlet. The creek was originally used by indigenous Suquamish peoples and called Duwe'iq, which is translated as "mouth of a creek way back in a pocket". The mouth/ estuary of the creek and Dyes Inlet were utilized as a winter and fishing camp and known as Sa'qad meaning "to spear it' (Suquamish, 2015, CRC, 2013). The name refers to the area's high production of Coho (Oncorhynchus kisutch), chum (Oncorhynchus keta), Chinook (Oncorhynchus tshawytscha) salmon and steelhead trout (Oncorhynchus mykiss) prior to European settlement and development in the area (CCFR, 2014, CRC, 2013). Forage fish and shellfish were also abundant. Washington Department of Fish and Wildlife (DFW) records indicates the presence of these species in the Clear Creek watershed (DFW - SalmonScape, 2016).

After European settlement, the estuary continued to experience unimpeded diurnal inundation until 1948. At that time, the 1907 trestle bridge connecting Silverdale to eastside Traceyton was replaced with an embankment-based bridge that bisected the estuary. This structure reduced the tidal exchange path to one culvert on the east end of the bridge. A lagoon formed to the southwest of the Best Family farm "Tide's End" [figure 3]. Phil Best, childhood resident from 1944 through 1958, recalls that "I didn't count them nor did I recognize the species as a kid and the run wasn't as large as Chico Creek, but hundreds of salmon swam through the estuary each fall and steelhead used the lagoon too." In 1958 a second culvert was added.

\section{Vegetation}

Historical vegetation varied with the landscape. There were uplands, wetlands, and shoreline species in the immediate vicinity of the estuary. Trees and shrubs in the mixed shoreline forests included Western hemlock (Tsuga heterophylla), red alder (Alnus rubra), black cottonwood (Populus balsamifera ssp. trichocarpa), big leaf maple (Acer macrophyllum), Western red cedar (Thuja plicata), Douglas fir (Pseudotsuga menziesii spp. menziesii), Ocean spray (Holodiscus discolor), black twinberry (Lonicera involucrata), red elderberry (Sambucus racemose spp. pubens), Oso berry (Oemleria cerasiformis), trailing black current (Ribes taxiflorum), Nootka rose (Rosa nutkana), salmonberry (Rubus spectibilis), thimbleberry (Rubus parviflorus), and trailing blackberry (Rubus ursinus) (Otak - BA, 2013, Otak -WA, 2013). 
Ground covers and grasses included redwood sorrel (Oxalis oregano), vanilla-leaf (Achlys triphylla) saltmarsh grass (Distichlis spicata), Lyngbye's sedge (Carex lyngbyei), and sea arrowgrass (Triglochin maritimum) (Otak - BA, 2013).

Nearby wetland species included Hardhack (Spiraea douglasii spp. douglasii), Pacific willow (Salix luicide spp. lasiandra) Sitka willow (Salix stichensis), sweet gale (Myrica gale), cattail (Typha latifolia), vine maple (Acer circinatum), red-osier dogwood (Cornus stolonifera), skunk cabbage (Lysichiton americanum), pacific bleeding hearts (Dicentra formosa), licorice fern (Polypodium glycyrrhiza), Alaska or swamp bentgrass (Argotis aequivalvis), and sword fern (Polystichum munitum) (Otak - WA, 2013).

The marine shoreline plants community was composed of Puget Sound gumweed (Gridelia integrifolia), silver burweed (Ambrosia chamissonis), sea plantain (Plantago maritime ssp. juncoides), jaumea (Jaumea carnosa), perennial saltwort or pickleweed (Salicornia virginica), silverweed (Potentilla anserine ssp. pacifica), Douglas' aster (Aster subspicatus or Aster douglasii), red algae (Rhodymenia palmate), green algae (Ulva lactuca), and bladderwrack (Fucus vesiculosus) (DEIS, 1987).

\section{Industry}

Agriculture and timber were mainstays of the economy near the estuary from the mid nineteenth to mid twentieth century ( $\underline{C R C, 2013})$. A lumber mill was located just above the western nearshore [figure 4] and a dairy farm [figure 3] was located on the higher banks of the eastern side the estuary from 1944 through 1993 when the property was donated to the Kitsap Land Conservancy (KCHS, 2014, CRC, 2013). The ecological impacts of these two industries are uncertain although remnant evidence of the mill exists along the beach of Old Mill Park. For instance, core boring samples from the Mill Pond area collected during the geotechnical survey identified a sawdust deposit layer underlying mucky soils (Aspect, 2013).

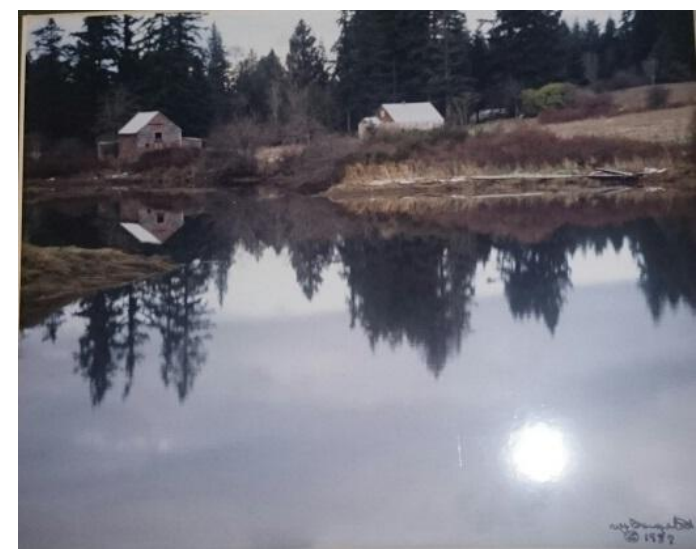

Figure 3: Smith Farm formerly known as "Tide's End" on northeastern side of Clear Creek Estuary and Bucklin Hill Bridge. Courtesy of Stacy Bargerstock, 1987

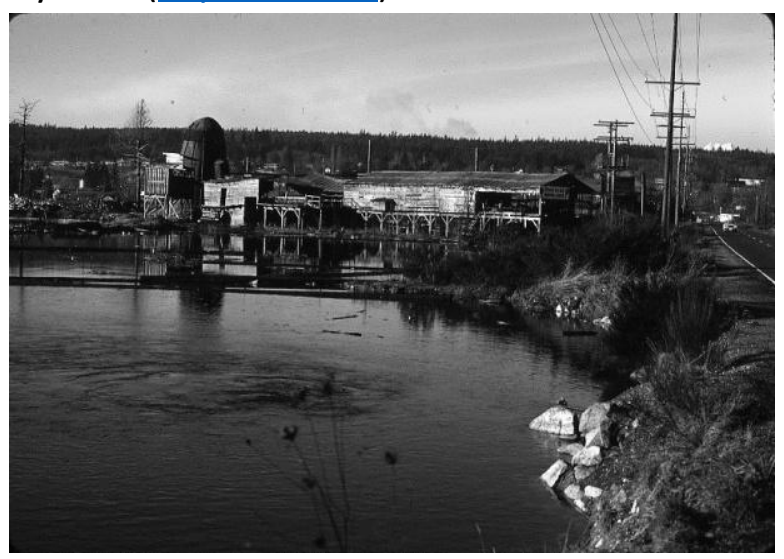

Figure 4: Sneebeck Mill located immediately southwest of Clear Creek Estuary circa 1958. Courtesty of Kitsap County Historical Society. 
Urbanization of this largely rural area began in earnest in the mid 1960's with the upgrade to connectivity provided by Washington State Route 3 between 1968 and 1977. Several commercial businesses have been built near the creek and estuary (WSDOT, 1968). In addition, the Kitsap Mall was built slightly northwest of the estuary and opened for business in 1985.

Commercial development in the immediate vicinity of Clear Creek and its estuary continued at a rapid pace as illustrated in a comparison of the landscape in 1985 to 2012 [figure 5].

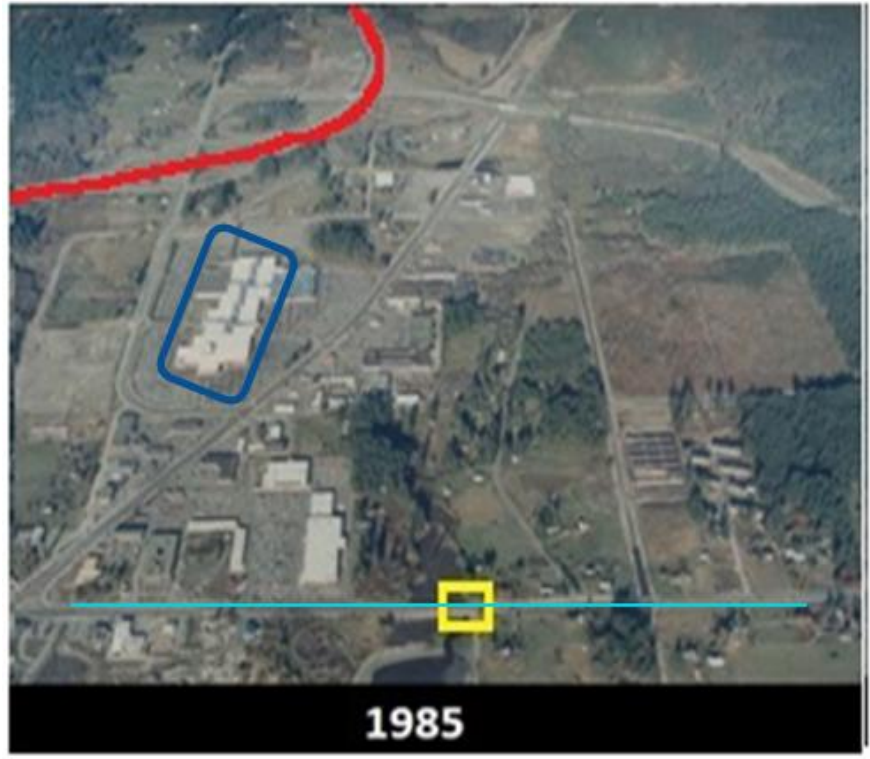

Bucklin Hill Road

Estuary

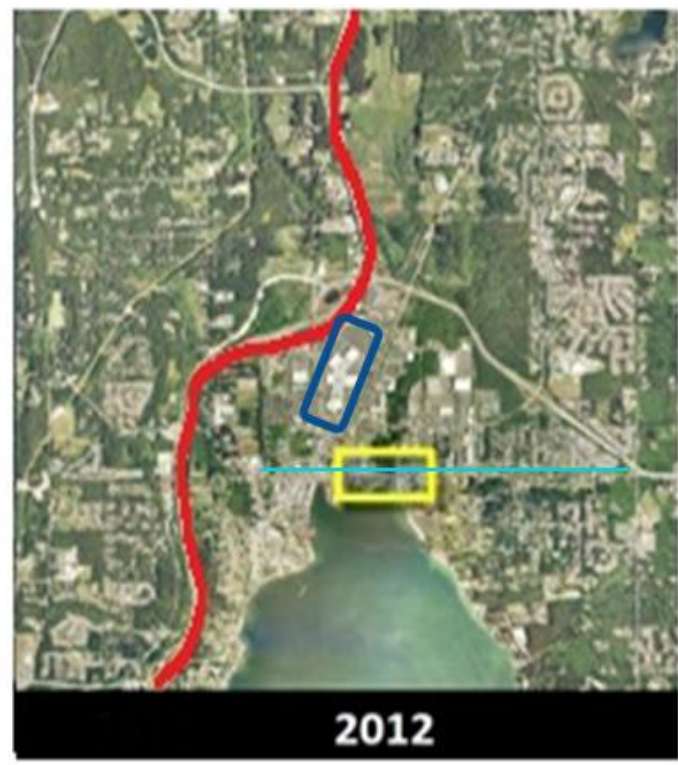

SR-3

Kitsap Mall

Figure 5: Transition towards urbanization in the Clear Creek Watershed over a 27 year period, particularly in the areas surrounding the Clear Creek's estuary (yellow rectangle) is illustrated by the increase in development along the shoreline and State Route 3 (shown in red) in the 2012 image compared to the 1985 aerial photograph. Kitsap Mall and Bucklin Hill Road are included as additional points of reference. [Adapted from Bucklin Hill Bridge Replacement \& Estuary Enhancement Project, Kitsap County 2014]

\section{Previous Studies and Contaminants of Concern}

The Clear Creek watershed is relatively small at 7.46 square miles (Dyes Inlet/Clear Creek Watershed Action Plan, 1991) however; it consists of many residential and an increasingly large number of commercial parcels. Wastewater is managed by the Central Kitsap Sewage Treatment Plant and discharges into Port Orchard Bay which lies to the south of Dyes Inlet. Untreated stormwater from impervious surface does flow into Clear Creek and Dyes Inlet (OtakBA, 2013). A 2005 Kitsap Public Works study identified outfall from outdated stormwater infrastructure in the commercial corridor ( $0.8 \mathrm{~km}$ or $1 / 2$ mile north of the estuary) as likely sources of poor water quality conditions in the creek and estuary (Fohn, 2009). Stormwater runoff along with the lack of tidal mixing may be influencing dissolved oxygen (DO) and fecal coliform (FC) concentrations - both have been identified as water quality concerns in Clear Creek. Elevated FC levels are likely to be an indirect factor in the unacceptably low DO levels. FC bacteria are anaerobic organisms, so they do not directly consume oxygen. However, FC 
presence in water samples is indicative of organic matter (in which the bacteria occur) undergoing decomposition. The biological oxygen demand created during the decomposition of organic carbon to carbon dioxide along with oxidation of nitrogenous compounds may deplete dissolved oxygen supplies (Delzer, et al., 2003).

Dyes Inlet and Clear Creek have been listed as impaired water bodies. The stream was added to the Washington State Department of Ecology's (DOE) 303d listing of impaired waters for inadequate levels of DO in 2004 and for excess levels of FC concentrations since 1998. FC standards for Washington are less than $14 \mathrm{cfu} / 100 \mathrm{~mL}$ sample (geomean) or $43 \mathrm{cfu} / 100 \mathrm{~mL}\left(90^{\text {th }}\right.$ percentile) for marine waters and less than $100 \mathrm{cfu} / 100 \mathrm{~mL}$ (geomean) or $200 \mathrm{cfu} / 100 \mathrm{~mL}\left(90^{\text {th }}\right.$ percentile) for freshwater. FC data collected in the marine waters south of the estuary also known as the head of Dyes Inlet (DY27) [table 1] and upstream, approximately $1 / 4$ mile north of it (CC01) show an improving trend in the detected levels [table 2].

Table 1: Kitsap County Health Department Saltwater Fecal Coliform (FC) Bacteria sampling results submitted to Washington State Department of Ecology (DOE) over the period of 2004-2015. Geometric mean values (GMV) results are generally less than 100 colonies per 100 milliliter of sample water. In 6 of the 12 years, results demonstrate excursions from DOE fecal coliform water quality standards (FCWOS) in the percentage of samples test wherein samples contained more than 43 colonies per $100 \mathrm{~mL}$ of sample water. [Adapted from Kitsap County Health Dyes Inlet Final Report, Kitsap Co. Health Department, and DOE EIMData].

\begin{tabular}{|c|c|c|c|c|c|c|}
\hline Year & $\begin{array}{l}\text { \#of } \\
\text { Samples }\end{array}$ & $\begin{array}{l}\text { Range } \\
\text { (FC/100mL) }\end{array}$ & $\begin{array}{l}\text { GMV } \\
\text { (FC/100mL) }\end{array}$ & $\begin{array}{l}\text { \# Samples > } 43 \\
\text { FC } / 100 \mathrm{~mL}\end{array}$ & $\begin{array}{l}\text { \% Samples }>43 \\
F C / 100 m\end{array}$ & $\begin{array}{l}\text { Meets } \\
\text { FCWQS }\end{array}$ \\
\hline 2004 & 2 & $4-13$ & 7.2 & 0 & 0 & YES \\
\hline 2005 & 1 & $1-50$ & 2.7 & 1 & $14.3 \%$ & NO \\
\hline 2006 & 14 & $2-240$ & 21.5 & 3 & $21.5 \%$ & NO \\
\hline 2007 & 17 & $1-80$ & 2.4 & 1 & $6.35 \%$ & YES \\
\hline 2008 & 10 & $1-500$ & 4.4 & 2 & $20.0 \%$ & NO \\
\hline 2009 & 12 & $1-900$ & 7.1 & 3 & $25.0 \%$ & $\mathrm{NO}$ \\
\hline 2010 & 9 & $1-72$ & 9.0 & 2 & $22.0 \%$ & $\mathrm{NO}$ \\
\hline 2011 & 12 & $0.75-24.5$ & 3.33 & 0 & 0 & YES \\
\hline 2012 & 12 & $0.5-61.5$ & 5.71 & 2 & $16.7 \%$ & NO \\
\hline 2013 & 12 & $0.5-296.5$ & 4.49 & 1 & $8.3 \%$ & YES \\
\hline 2014 & 12 & $0.5-24.5$ & 4.14 & 0 & $0 \%$ & YES \\
\hline 2015 & 12 & $0.5-10.25$ & 2.88 & 0 & $0 \%$ & YES \\
\hline
\end{tabular}

Table 2 Kitsap County Health Department Freshwater Fecal Coliform (FC) Bacteria sampling results submitted to Washington State Department of Ecology (DOE) over the period of 2004-2015. Clear Creek failed to meet DOE standards for Geometric mean values (GMV) maximums of 100 colonies per $100 \mathrm{~mL}$ of sampled water or percentage of samples with FC colonies greater than 200 per $100 \mathrm{~mL}$ of sample water in 2004-2013. (Adapted from Kitsap County Health Dyes Inlet Final Report and DOE EIMData).

\begin{tabular}{|c|c|c|c|c|c|c|}
\hline Year & $\begin{array}{c}\text { \# of } \\
\text { samples }\end{array}$ & $\begin{array}{c}\text { Range } \\
\text { (FC/100ml) }\end{array}$ & $\begin{array}{c}\text { GMV } \\
\text { (FC/100ml) }\end{array}$ & $\begin{array}{c}\text { \# Samples }>200 \\
\text { FC } / 100 \mathrm{ml}\end{array}$ & $\begin{array}{c}\text { \% Samples } \\
>200 \mathrm{FC} / 100 \mathrm{ml}\end{array}$ & $\begin{array}{c}\text { Meets FC } \\
\text { WQS }\end{array}$ \\
\hline 2004 & 12 & $17-900$ & 121 & 4 & $33.3 \%$ & NO \\
\hline 2005 & 12 & $17-1600$ & 143 & 5 & $41.7 \%$ & NO \\
\hline 2006 & 12 & $4-300$ & 78 & 3 & $25.0 \%$ & NO \\
\hline 2007 & 12 & $23-1600$ & 136 & 3 & $25.0 \%$ & NO \\
\hline 2008 & 13 & $11-1600$ & 136 & 2 & $15.4 \%$ & NO \\
\hline 2009 & 12 & $4-300$ & 30 & 2 & $16.7 \%$ & NO \\
\hline 2010 & 12 & $8-300$ & 42 & 2 & $16.7 \%$ & NO \\
\hline 2011 & 11 & $4-400$ & 60 & 2 & $18.2 \%$ & NO \\
\hline
\end{tabular}




\begin{tabular}{|c|c|c|c|c|c|c|}
\hline Year & $\begin{array}{c}\text { \# of } \\
\text { samples }\end{array}$ & $\begin{array}{c}\text { Range } \\
\text { (FC/100ml) }\end{array}$ & $\begin{array}{c}\text { GMV } \\
\text { (FC/100ml) }\end{array}$ & $\begin{array}{c}\text { \# Samples >200 } \\
\text { FC/100ml }\end{array}$ & $\begin{array}{c}\text { \% Samples } \\
>200 \mathrm{FC} / 100 \mathrm{ml}\end{array}$ & $\begin{array}{l}\text { Meets FC } \\
\text { WQS }\end{array}$ \\
\hline 2012 & 12 & $4-1180$ & 42 & 2 & $16.7 \%$ & NO \\
\hline 2013 & 12 & 4-2001 & 41 & 2 & $16.7 \%$ & NO \\
\hline 2014 & 11 & $4-640$ & 43 & 1 & $9.1 \%$ & YES \\
\hline 2015 & 12 & $10-120$ & 31 & 0 & $0.0 \%$ & YES \\
\hline
\end{tabular}

Dissolved oxygen standards for Aquatic Life Uses thresholds are assigned under freshwater or marine use categories [table 3]. Specific WA WQS support for determining criteria applicable to estuarine or "brackish" water bodies is being developed by the Department of Ecology Water Quality Division [personal communication, Chad Brown, WA DOE, May 18, 2016]. Drafted guidance bases the appropriate freshwater or marine use category selection upon the annual vertically averaged daily maximum salinity values (VADMAX). As provided within the subsection 260(3)(e)(ii):

- "fresh water criteria must be applied at any point where ninety-five percent of the salinity values are less than or equal to one part per thousand.

- marine water criteria must apply at all other locations where the salinity values are greater than one part per thousand"

Surface water criteria are also established by Washington State legislation related to $\mathrm{pH}$ [table 5] temperature [table 6], and toxic substances such as copper and zinc [Appendix F] for both fresh and marine waters.

Table 3: Beneficial Use categories for dissolved oxygen criteria in estuaries as promulgated in Washington State Law. (Adapted from WAC 173-201A-200(1)(d) - freshwater and WAC 173-201A-210(1)(d)- marine)

\begin{tabular}{|c|c|c|c|c|}
\hline $\begin{array}{l}\text { Use } \\
\text { Type }\end{array}$ & Freshwater Use Category & 1-day Minimum DO* & Marine Use Category & 1-day Minimum DO* \\
\hline \multirow{7}{*}{ 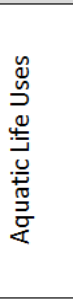 } & Char spawning and rearing & \multirow{2}{*}{$\geq 9.5 \mathrm{mg} / \mathrm{L}$} & \multirow{2}{*}{ Extraordinary quality } & \multirow[t]{2}{*}{$\geq 7.0 \mathrm{mg} / \mathrm{L}$} \\
\hline & Core summer salmonid habitat & & & \\
\hline & $\begin{array}{l}\text { Salmonid spawning, rearing, and } \\
\text { migration }\end{array}$ & $\geq 8.0 \mathrm{mg} / \mathrm{L}$ & Excellent quality & $\geq 6.0 \mathrm{mg} / \mathrm{L}$ \\
\hline & Salmonid rearing and migration only & $\geq 6.5 \mathrm{mg} / \mathrm{L}$ & Good quality & $\geq 5.0 \mathrm{mg} / \mathrm{L}$ \\
\hline & $\mathrm{N} / \mathrm{A}$ & $\mathrm{N} / \mathrm{A}$ & Fair quality & $\geq 4.0 \mathrm{mg} / \mathrm{L}$ \\
\hline & $\begin{array}{l}\text { Non-anadromous interior redband } \\
\text { trout }\end{array}$ & $\geq 8.0 \mathrm{mg} / \mathrm{L}$ & \multirow{2}{*}{\multicolumn{2}{|c|}{$\begin{array}{l}\text { *When a water body's D.O. is lower than the criteria above within } 0.2 \\
\mathrm{mg} / \mathrm{L} \text { of the criteria) and that condition is due to natural conditions, } \\
\text { then human actions considered cumulatively may not cause the D.O. } \\
\text { of that water body to decrease more than } 0.2 \mathrm{mg} / \mathrm{L} \text {. }\end{array}$}} \\
\hline & Indigenous warm water species & $\geq 6.5 \mathrm{mg} / \mathrm{L}$ & & \\
\hline
\end{tabular}

A recent soils report, The Bucklin Hill Bridge Project Geotechnical report identified one boring sample out of five as containing carcinogenic polycyclic aromatic hydrocarbons (cPAHs) above the continuous human residential contact standard reporting limit of 0.1 milligrams/kilograms $(\mathrm{mg} / \mathrm{kg})$ established by DOE. Using the DOE toxicity equivalency factor, that sample was calculated as $0.118 \mathrm{mg} / \mathrm{kg}$ (Aspect, 2013). In the Bucklin Hill Bridge project analysis, two key pollutants-dissolved zinc and dissolved copper were found to occur in the old mill pond. Core samples collected during the biological assessment (Otak-BA, 2013) indicate low levels of copper and zinc have adsorbed to sediment. In one core sample the copper concentration was reported as above water quality standards for toxins. Displacement of those soils could release these metals into nearby waters. 


\section{Present Stream Monitoring}

As of December 12, 2012, the U.S. EPA approved water quality assessment category for Dyes Inlet and Clear Creek related to fecal coliform (FC) levels is 4A. This category indicates that there is an approved Total Maximum Daily Loads (TMDL) or water quality implementation plan (WQI) in place that is actively being implemented to remediate that pollution [table 4]. Fecal coliform (FC) monitoring continues by Kitsap County Health District. From 1989 to 2012, FC percentages of samples exceeded Washington State water quality standards. As with much of the Puget Sound shoreline, shellfish gathering is not allowed due to elevated FC levels. In 2014, however the creek did not have a health advisory issued.

Table 4: Washington State Water Quality Assessment for Clear Creek and North Dyes Inlet indicates failure to meet the State's standards for fecal coliform bacteria (FC) in both the marine and freshwater environments. The categorization of Clear Creek and Dyes Inlet as 4A identifies there is an active Total Maximum Daily Load (TMDL) implementation plan for FC. Clear Creek is categorized as 5 for low dissolved oxygen levels (DO). Dyes Inlet has been assigned a category 2 rating, signifying concern for DO concentration levels based on trends, but with insufficient data available to require creation of a TMDL. Temperature is also rated category 2 for the Inlet. In Clear Creek, pH and polychlorinated biphenyls (PCB) levels have been assigned to category 2 (WA DOE - WQA, 2016).

\begin{tabular}{|c|c|c|}
\hline \multicolumn{3}{|c|}{$\begin{array}{l}\text { WASHINGTON STATE WATER QUALITY ASSESSMENT FOR } \\
\text { CLEAR CREEK AND NORTH DYES INLET }\end{array}$} \\
\hline LOCATION & LISTED PARAMETERS & CATEGORIES \\
\hline \multicolumn{3}{|l|}{ 303d Listings } \\
\hline \multirow[t]{4}{*}{ Clear Creek } & Dissolved Oxygen & 5 \\
\hline & Fecal coliform bacteria & $4 \mathrm{~A}$ \\
\hline & $\mathrm{pH}$ & 2 \\
\hline & PCB & 2 \\
\hline \multirow[t]{3}{*}{ Dyes Inlet } & Dissolved Oxygen & 2 \\
\hline & Fecal coliform bacteria & $4 \mathrm{~A}$ \\
\hline & Temperature & 2 \\
\hline \multicolumn{3}{|c|}{ Shellfish Classification } \\
\hline \multicolumn{2}{|c|}{ North Dyes Inlet near Silverdale } & Prohibited \\
\hline
\end{tabular}

Dissolved oxygen content is unacceptable in the creek, but within acceptable limits in the inlet as of 2014. DO is listed as category 5 impaired. TMDL are required for the water bodies in this category; however there has been no TMDL or pollution control plan implemented for addressing DO in Clear Creek to date (DOE, 2012).

Other parameters being monitored include $\mathrm{pH}, \mathrm{PCBs}$, and temperature. Each of these water quality factors has been assigned to Category 2, i.e.: they have not been shown to be in violation of water quality standards however the parameters are items of possible concern. Monitoring results may reveal values close to guidance limits, negative trends in quality, or sampling/process did not follow established protocols. However data do not exist which warrant a TMDL or to execute a water quality implementation plan. (DOE-303d Categories, 2016) WA WQS applicable to Aquatic Life Uses for $\mathrm{pH}$ and water temperature [tables 5 and 6 ] are used for comparison to data currently being collected in Clear Creek and Dyes Inlet by the Kitsap Health Department [table 7]. Conventional water quality parameters, such as temperature, $\mathrm{pH}, \mathrm{DO}$, and conductivity were collected and reported from October 2004 
through September 2008 for the freshwater site (CC01) and October 2005 through September 2015 for the marine water site (DY27). An expanded dataset is available in Appendix C.

Table 5: Washington State Water Quality Standards related to pH for Aquatic Life Uses as promulgated in Washington State Law. (Adapted from WAC 173-201A-200(1)(g) - freshwater and WAC 173-201A-210(1)(f)- marine). Marine water uses allow for a larger range in $\mathrm{pH}$ level (6.5 to 9.0) than freshwater uses $\mathrm{pH}$ (6.5 to 8.5))

\begin{tabular}{|c|c|c|c|c|}
\hline $\begin{array}{l}\text { Use } \\
\text { Type }\end{array}$ & Freshwater Use Category & Range & Marine Use Category & Range \\
\hline \multirow{5}{*}{ 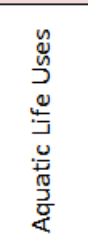 } & Char Spawning and Rearing* & \multirow{2}{*}{6.5 to 8.5} & Extraordinary quality* & 7.0 to 8.5 \\
\hline & Core Summer Salmonid Habitat* & & Excellent quality + & 7.0 to 8.5 \\
\hline & Salmonid Spawning, Rearing, and Migration+ & \multirow{2}{*}{6.5 to 8.5} & Good quality+ & 7.0 to 8.5 \\
\hline & Salmonid Rearing and Migration+ & & Fair quality + & 6.5 to 9.0 \\
\hline & \multicolumn{2}{|c|}{$\begin{array}{l}\text { *human-caused variation within the above range of less } \\
\text { than } 0.2 \text { units }\end{array}$} & \multicolumn{2}{|c|}{$\begin{array}{l}\text { + human-caused variation within the above } \\
\text { range of less than } 0.2 \text { units }\end{array}$} \\
\hline
\end{tabular}

Table 6: Washington State Water Quality Standards related to temperature requirements for Aquatic Life Uses as promulgated in Washington State Law. (Adapted from WAC 173-201A-200(1)( c) - freshwater and WAC 173-201A-210(1)(c)- marine). The freshwater maximum temperatures are slightly lower for all species than for any marine species use.

\begin{tabular}{|c|c|c|c|c|}
\hline $\begin{array}{l}\text { Use } \\
\text { Type }\end{array}$ & Freshwater Use Category & $\begin{array}{l}\text { 7-day Maximum } \\
\text { Temperature } \\
\text { (7-DADMax)^ }\end{array}$ & Marine Use Category & $\begin{array}{l}\text { 1-day Maximum } \\
\text { Temperature (1-DMax)^ }\end{array}$ \\
\hline \multirow{7}{*}{ 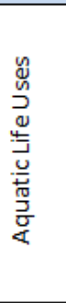 } & Char Spawning and Rearing* & $12^{\circ} \mathrm{C}\left(53.6^{\circ} \mathrm{F}\right)$ & Extraordinary quality & $13^{\circ} \mathrm{C}\left(55.4^{\circ} \mathrm{F}\right)$ \\
\hline & Core Summer Salmonid Habitat* & $16^{\circ} \mathrm{C}\left(60.8^{\circ} \mathrm{F}\right)$ & Excellent quality ${ }^{+}$ & $16^{\circ} \mathrm{C}\left(60.8^{\circ} \mathrm{F}\right)$ \\
\hline & Salmonid Spawning, Rearing, and Migration* & $17.5^{\circ} \mathrm{C}\left(63.5^{\circ} \mathrm{F}\right)$ & Good quality & $19^{\circ} \mathrm{C}\left(66.2^{\circ} \mathrm{F}\right)$ \\
\hline & Salmonid Rearing and Migration Only & $17.5^{\circ} \mathrm{C}\left(63.5^{\circ} \mathrm{F}\right)$ & $\begin{array}{l}\text { Fair quality } \\
\end{array}$ & $22^{\circ} \mathrm{C}\left(71.6^{\circ} \mathrm{F}\right)$ \\
\hline & Non-anadromous interior redkand trout & $18^{\circ} \mathrm{C}\left(64.4^{\circ} \mathrm{F}\right)$ & \multicolumn{2}{|c|}{$\begin{array}{l}-13^{\circ} \mathrm{C}\left(55.4^{\circ} \mathrm{F}\right) \text { at the initiation of spawning for salmon and at fry emergence for salmon } \\
\text { and trout. }\end{array}$} \\
\hline & Indigenous warm water species & $20^{\circ} \mathrm{C}\left(68^{\circ} \mathrm{F}\right)$ & \multicolumn{2}{|c|}{$\begin{array}{l}\text { +Lethality to developing fish embryos can be expected to occur at a 1-DMax temperature } \\
\text { greater than } 17.5^{\circ} \mathrm{C}\left(63.5^{\circ} \mathrm{F}\right)\end{array}$} \\
\hline & \multicolumn{4}{|c|}{ 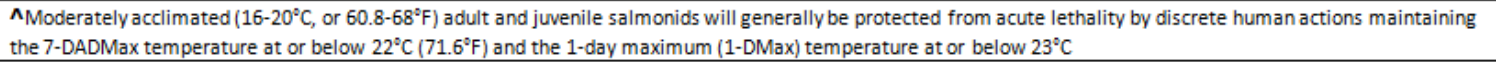 } \\
\hline
\end{tabular}

Table 7: Water quality parameters collected near Clear Creek Estuary from October 2005 through September 2015. Freshwater samples were collected at station CCO1 which is located approximately 1/4 mile north of the estuary. Saltwater samples were collected at station DY27 which is located approximately $1 / 4$ mile south of the estuary. N/A values denote that no WA WQS has been established (Adapted from Kitsap County Health Dept. Dyes Inlet Final Report, 2009 \& Dyes Inlet Final Report, 2015).

\begin{tabular}{|c|c|c|c|c|c|}
\hline Station & Year & Parameter & \# of Samples & Samples Range & Meets WQS \\
\hline \multirow[t]{6}{*}{ CC01 } & \multirow[t]{3}{*}{$10 / 01 / 2005$ to $9 / 30 / 2009$} & DO & 47 & $8.6-12.8 \mathrm{mg} / \mathrm{L}$ & Yes \\
\hline & & $\mathrm{pH}$ & 47 & $7.2-8.3$ & Yes \\
\hline & & Temperature & 47 & $3.4-13.9^{\circ} \mathrm{C}$ & Yes \\
\hline & \multirow[t]{3}{*}{$10 / 01 / 2010$ to $9 / 30 / 2015$} & DO & \multirow{3}{*}{\multicolumn{3}{|c|}{ None reported }} \\
\hline & & $\mathrm{pH}$ & & & \\
\hline & & Temperature & & & \\
\hline \multirow[t]{8}{*}{ DY27 } & \multirow[t]{4}{*}{$10 / 01 / 2005$ to $9 / 30 / 2009$} & DO & 8 & $6.3-14.8 \mathrm{mg} / \mathrm{L}$ & YES \\
\hline & & $\mathrm{pH}$ & 5 & $8.0-8.6$ & YES \\
\hline & & Salinity & 41 & $6.4-33.2$ & $N / A^{*}$ \\
\hline & & Temperature & 39 & $6.7-24.6$ & NO \\
\hline & \multirow[t]{4}{*}{$10 / 01 / 2010$ to $9 / 30 / 2015$} & DO & 0 & 0 & UNKNOWN \\
\hline & & $\mathrm{pH}$ & 20 & $7.2-8.3$ & YES \\
\hline & & Salinity & 71 & $4.6-30.6$ & $N / A^{*}$ \\
\hline & & Temperature & 71 & $5.1-20.9$ & Yes \\
\hline
\end{tabular}


Clean Water Kitsap, a division of Kitsap County Public Works, and citizen volunteers conduct benthic macroinvertebrate sampling at an upstream location in the main stem and at one spot in the west fork of Clear Creek. The lower mainstem location, near the heavily trafficked Ridgetop Blvd and 0.25 miles north of the estuary is a "Tier 1" site. A tier 1 site is sampled annually due to likely impacts from stormwater. Samples taken in 2010 through 2013 indicate an improvement in the biotic Index (BI). The west fork location is a "Tier 2" site. Tier 2 sites are sampled every other year. While stormwater impacts are possible, they are expected to be less severe than tier 1 locations. Data collected in 2011 and 2013 illustrate a decrease in the BI value [table 8].

Table 8: Stream Benthos Monitoring 2010-2013 results in terms of their Biotic Index indicate the mainstem of Clear Creek of has improving richness while the west fork is declining over the sampling period. Adapted from Kitsap County Dept of Public Works - Stormwater Division (Jul 2014)

\begin{tabular}{|c|c|c|c|c|c|c|}
\hline $\begin{array}{c}\text { Sample } \\
\text { Location }\end{array}$ & Tier & $\mathbf{2 0 1 0}$ & $\mathbf{2 0 1 1}$ & $\mathbf{2 0 1 2}$ & $\mathbf{2 0 1 3}$ & $\mathbf{2 0 1 4}$ \\
\hline Main stem & 1 & $\begin{array}{c}\text { Very Poor } \\
(0-19)\end{array}$ & $\begin{array}{c}\text { Poor } \\
(20-39)\end{array}$ & Poor & $\begin{array}{c}\text { Fair } \\
(40-59)\end{array}$ & $\begin{array}{c}\text { Lab results } \\
\text { pending }\end{array}$ \\
\hline West Fork & 2 & Not sampled & $\begin{array}{c}\text { Good } \\
(60-79)\end{array}$ & Not sampled & $\begin{array}{c}\text { Fair } \\
(40-59)\end{array}$ & Not sampled \\
\hline
\end{tabular}

In addition, stream flow is continuously monitored by Kitsap Public Utilities Department (KPUD) via telemetered gauges. Data are collected approximately $1.3 \mathrm{~km}$ ( $0.8 \mathrm{miles})$ north of the estuary. Flow data available for the mainstem of Clear Creek record ranges from 2 to 235 cubic feet per second [cfs] (KPUD, 1997). Water years are inclusive of October through September. Average discharges at this upstream site for the water years of 2013-2014 and 2014-2015 were of 7.95 and $9.72 \mathrm{cfs}$, respectively (KPUD, 2016).

\section{E. Current Hydrological Conditions in the Estuary}

In addition to challenges associated with managing anthropogenic inputs of stormwater, the basic freshwater and marine water exchange has been disturbed (Otak - WA, 2013). The bridge separating Dyes Inlet and Clear Creek (the Bucklin Hill Bridge) is a low elevation structure built on a 13 foot high, man-made land extension composed of soil, timber, and rock which bisects the estuary (KCPW, 2013; Otak - BA, 2013; Otak - WA, 2013). Creek egress and tidal inundation are both channeled through two six-foot culverts that connect Clear Creek to Dyes Inlet. The culverts are inset into the embankment supporting the bridge structure. Ecological functions such as nutrient exchange and sediment transport have been degraded as a result of the berm and culverts constriction of the estuary (Otak - BA, 2013). This condition is a common effect of dam and dam-like structures (Bednarek, 2001) and the Clear Creek Estuary is no exception. 


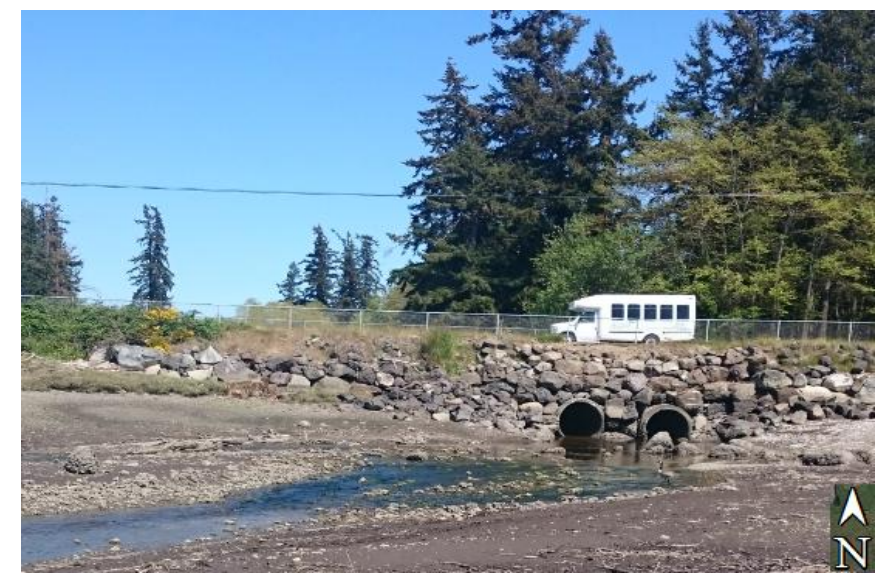

Figure 6: Erosion on the marine side of the Bucklin Hill Bridge culverts has created perched culverts above the stream bed thereby

restricting access for incoming salmon to high tide periods. June 2015

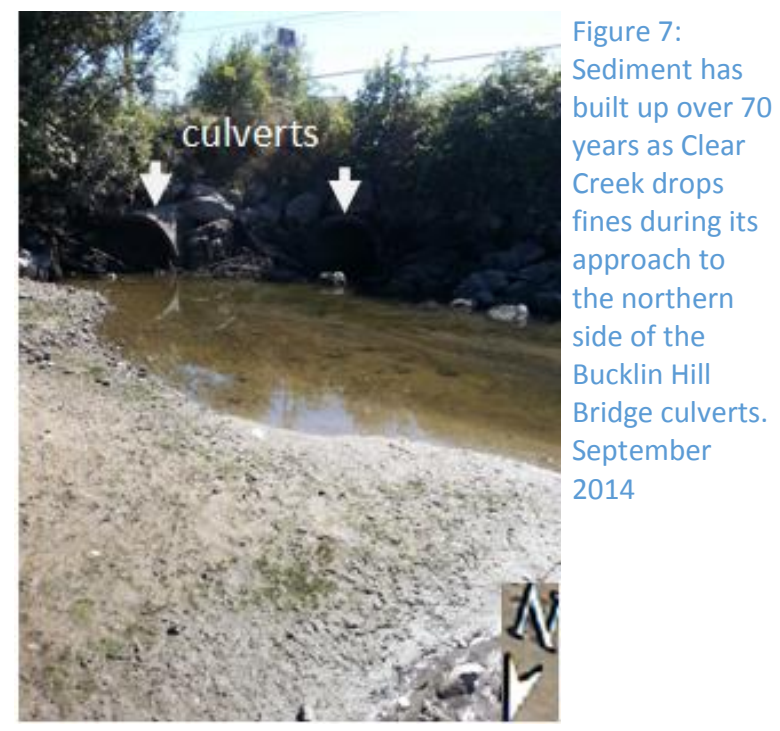

Significant erosion has occurred on the marine side [southern - figure 6] of the barrier resulting in sandy gravel below "perched" culverts, that is the culverts sit above the stream bed. This elevated position of the culverts has limited access to the creek for returning salmon to periods of high tides (KCPW, 2013, CRC, 2013). The creek's inland side [northern - figure 7] has accumulated stockpiles of silts and fines for nearly half a century. Silty sand has accumulated on both sides of the bridge, thereby reducing the quantity of exposed in-stream cobble (Otak - BA, 2013).

The creek and estuary are protected from direct development by a 200 foot buffer. This set back allows for some native vegetative protection and infiltration of precipitation and stormwater, reducing overland stormwater flows directly into the creek (Otak, 2013). In addition a propitious event has created the opportunity to actively pursue salmon habitat restoration in the estuary. In January 2014 approval was obtained by Kitsap County Public Works to replace the Bucklin Hill Bridge with a structure that will allow restoration of the estuary to more historic conditions (KCPW, 2015).

\section{Bridge Project Site Description}

The 2015-2016 Bucklin Hill Bridge project will remove the culverts and anthropogenic embankment that the bridge currently sits upon [figure 8]. The current two lane bridge will be widened to accommodate four vehicular traffic lanes and two five foot bike lanes over a 240foot, four span bridge that sits five feet higher above the existing Bucklin Hill roadway [figure 9]. The new open design of the bridge will allow a more natural flow of water, nutrients, and sediments between the inlet and the creek (KCPW, 2013, CRC, 2013). This renovation is designed to restore natural tidal hydrologic fluctuations, reclaim some of the historic intertidal habitat, remove fish passage barriers, eliminate localized scour, and reduce fine sediment depositional problems. An additional 0.88 acres of "pollution generating" impervious surfaces will result from the project, therefore new state of the art "Filtera" style bio-retention storm 
drainage facilities will be installed at the abutments and along pedestrian lanes to capture and treat road runoff to meet or exceed Washington State Department of Ecology standards. Both the east and west outfalls will be replaced. The west side outfall will include a tide gate for fish exclusion and concrete pad for energy dissipation. The east side outfall design includes a screened energy diffusing trough running parallel to and along the full length of the abutment. (Otak - BA, 2013). Pedestrian access ramps to estuary viewing platforms on the bridge and separate trail access to the beach beneath it will be added. Utilities currently buried in the roadway fill such as power lines, telecommunications lines, sewer and stormwater pipes will be relocated. Nine of the utility lines will be mounted under the bridge. The power lines will run overhead of the new bridge (KCPW, 2013; KCPW 2015).

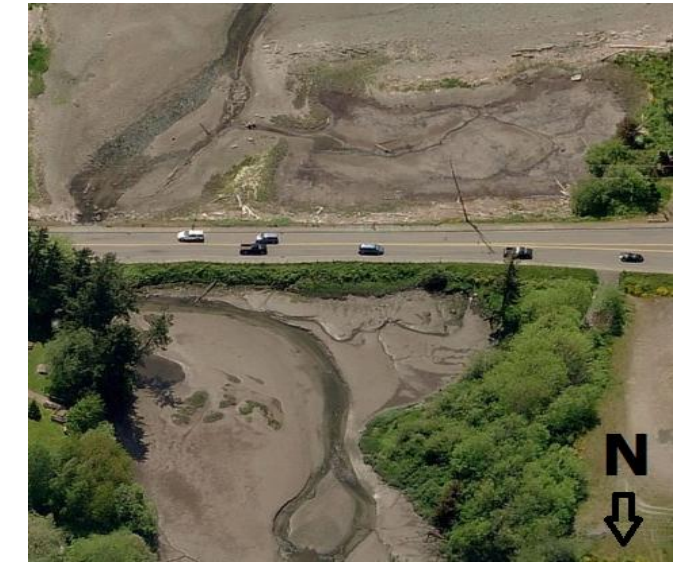

Figure 8: Existing Bucklin Bridge consists of two lanes over an embankment and two 72 inch culverts (Courtesy of Google Earth May 2014)

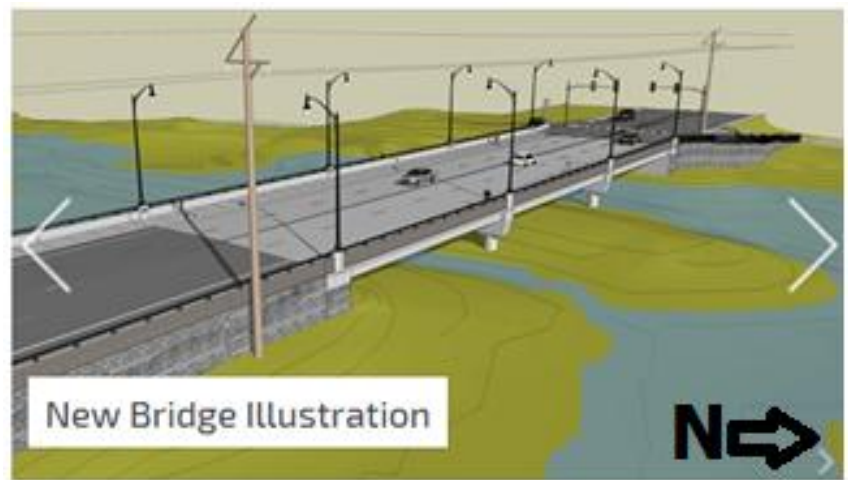

Figure 9: Artistic rendition of new four lane open span bridge with two creek channels. Courtesy of Kitsap County Public Works: Bridge Illustrations

Impacts to the nine nearby wetlands from the existing structure and the upcoming construction are intended to be mitigated by the removal of angular rock and improvements in stream/marine water exchange under the new bridge (Berger/Abam Engineers, 1998). Exchange facilitation will be enhanced via minor in stream dredging around the supporting piers in the existing channel under the eastside as well as the addition of an "overflow" channel under the western segment of the bridge (Aspect, 2013). Derelict piers will be removed from the nearshore which will reduce creosote seepage into the area waters. The assumption is that natural tidal flows will restore the functionality of the estuary to suitable salmon habitat (Otak ElS Addendum, 2013).

The draft environmental impact assessment statement (DEIS, 1987) related to the project presumed salmon habitat would be enhanced precluding the need for monitoring the outcome. In addition, while the response to comments in the final EIS acknowledges the lack of required habitat monitoring is an oversight (Berger- FEIS, 1998) no non-construction activity monitoring program has been announced by the project sponsors. However, a systematic confirmation of the benefits is a more thorough approach to planning for the restoration. Monitoring the 
changes in the estuary and lower section of the Clear Creek is a methodical way to determine whether the bridge replacement has in fact improved salmon habitat (Margules, et al., 2001)

\section{Salmonids}

A. Habitat Needs

Salmon, as anadromous fish, have different habitat needs at different stages in their lives: they are hatched in freshwater and rear in the estuarine waters where fresh and salt waters mix; and the salmon then spend the majority of their adult lives in the marine waters of open seas before returning to their natal streams where they will spawn and then expire (figure 10). Their corpses can provide marine based nutrients to birds, plants, and macroinvertebrates in their natal streams.

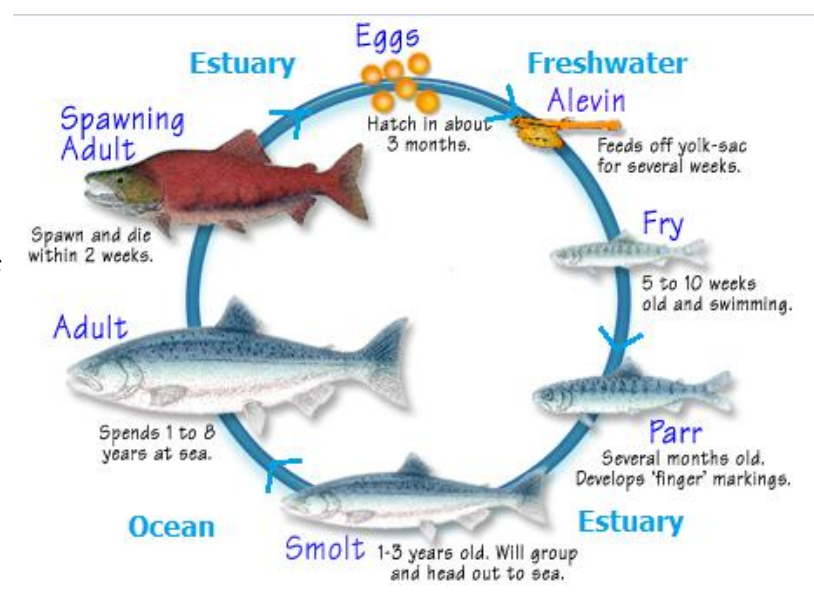

Figure 10: Pacific Salmon Life Cycle: Adapted from "The fascinating life cycle of an Alaska salmon from birth to spawning.

In order to migrate to suitable spawning streams, adult salmon require sufficiently deep water with temperatures that are equal to or less than $20^{\circ} \mathrm{C}$ as they travel through estuarine waters to freshwater (Carter, 2005). Migration can be impeded by delayed autumn rains as well as both natural and man-made barriers such as dams and culverts.

Desirable spawning grounds contain clean (unsilted) small to mid-sized gravels with cool, moderate streamflow and nearby pools for cover. Low stream flow provides poor aeration of eggs in redds, while high stream flows can cause a washout (WDFW, 2016). The salmon species historically known to utilize the Clear Creek Estuary do so differently. Coho travel further upstream to find spawning grounds while Chum will utilize the lower reaches nearer to saltwater. Chinook salmon will travel the greatest distance into a watershed to spawn. In the spring, once hatched the alevin are not in need of immediate external food sources due to their yolk sacs. Therefore they can remain protected in their redds. Upon complete consumption of this food supply they will leave the protection of the gravel nest. As fry, the young salmon will begin to rely on surrounding food sources such as aquatic invertebrates. Fry also need protection from predators. They will use undercut banks, pools, agitated surface waters, as well as areas around large woody debris for shelter. Clear and oxygenated water at temperatures less than $16^{\circ} \mathrm{C}$, are also requirements for healthy transition to the fry stage (WADOE- WQS, 2007).

Rearing habitat needs vary between species. Chinook and Coho fry remain in fresh water as they develop into parr. Chinook will grow for three to twelve months and Coho nearly 18 
months at the end of which time they develop into smolt. Chum fingerlings move rapidly into estuarine waters where they will utilize this environment as they grow into parr in preparation for their outgoing migration as smolts to marine water (WDFW, 2016).

Hormonally driven physiological changes occur during smoltification. These changes permit osmoregulation in salmonid, i.e., these modifications allow them to transition from a freshwater to saltwater habitat (Dickhoff, et al., 1997). Environmental factors can affect growth rates. Water quality (dissolved oxygen, heavy metal levels, and temperature), nutrition, and photoperiod have an influence on thyroid and hepatic hormones which directly affect smoltification morphology rates (EPA, 1977). Regardless of species, during smoltification, clear, cool water remains a critical component in the ability of the salmon to grow successfully into adults who are capable of avoiding predation (WDFW, 2016).

\section{B. Historic Conditions}

Suquamish history states that the Clear Creek estuary allowed passage of a great number of salmonids including Coho (Oncorhynchus kisutch), chum (O. keta), Chinook (O. tshawytscha) salmon and steelhead trout (O. mykiss) salmonids (Suquamish, 2015). Little historical data exist for Clear Creek, Dyes Inlet, or Kitsap County related to salmonid species abundance. Early twentieth century commercial steelhead capture records indicate large runs in Kitsap County. Steelhead harvest records from 1909 for Kitsap and nearby Thurston and Mason counties indicate several thousand escapements. (PSSTRT, 2013).

A 1971 Washington Department of Fish and Wildlife report on Water Resource Inventory Area 15 (WRIA 15), which covers Kitsap County, indicates large escapements in runs of fall Chinook, Coho, and fall chum salmon species in East Kitsap Streams between 1960 and 1971 [table 9] (DWF-WRIA15, 1971).

Table 9: Salmon species escapements recorded by the Washington Department of Wildlife and Fish during an 11 year period identify large numbers of Fall Chum, moderate counts of Coho, and small amounts of Fall Chinook evading capture and presumably able to spawn in East Kitsap County Streams.

\begin{tabular}{|llll|}
\hline Species & Years & Range & Average per Year \\
\hline Fall Chinook & $1966-1971$ & $530-2350$ & 1470 \\
Coho & $1960-1970$ & $6,650-27,800$ & 16,650 \\
Fall Chum & $1966-1971$ & $27,200-85,700$ & 46,850 \\
\hline
\end{tabular}

(Adapted from DWF-WRIA15, 1971)

Long time residents of the county in the Clear Creek area recall large numbers of salmonids using the estuary and stream, however few studies exist that provide specific counts for this stream. In a 1997 local waters assessment completed by Kitsap Public Utilities it was stated "Existing fisheries habitat information for much of the County is limited and does not provide a sufficient basis for an in-depth assessment" (KPUD, 1997). 


\section{Current Conditions}

Salmonid returns have continued to decrease due to environmental factors such as poor upstream access through the perched culverts, low dissolved oxygen, higher temperatures, and silted streams (Otak - BA, 2013). Anecdotal evidence indicates annual runs are no longer composed of hundreds of salmon.

A 2002 study of the estuary conducted by the Suquamish Tribe sampling documented a small number of chum and Chinook smolts [table 10] utilizing the Clear Creek Estuary habitat. Prior data is unavailable to confirm if and by what percentage use of the estuarine habitat has changed since the building of the Bucklin Hill Bridge embankment (Suquamish Tribe. 2003).

Table 10: Salmon species smolts captured in a 2002 seining at Clear Creek Estuary illustrate although both species occur in small numbers, juvenile Chinook and Chum were actively using the habitat. (Adapted from Dyes Inlet Estuary Study: Chico, Clear and Barker Estuaries December 2003)

\begin{tabular}{|l|l|l|}
\hline Scientific Name & Common name & Smolt \\
\hline Oncorhynchus tshawytscha & Chinook & 44 \\
\hline Oncorhynchus keta & Chum & 488 \\
\hline
\end{tabular}

\section{Monitoring Project Design}

Monitoring the Clear Creek Estuary before and after the completion of the Bucklin Hill Bridge Project is a critical part of ecosystem restoration planning and execution. Information from Who needs environmental monitoring? (Lovett, et al, 2007) and guidance provided by similar bridge replacement monitoring projects in Kitsap County, such as the Carpenter Creek/Appletree Cove Estuary (Palmer, et al., 2004), have been important references for designing this program to monitor the estuary. Lovett, et al. defines environmental monitoring as "a time series of measurements of physical, chemical, and/or biological variables, designed to answer questions about environmental change."

It is likely that the freer flow of water will be beneficial to not only to salmonids, but also to other aquatic life in the estuary. In a wider effort to characterize watershed health of Clear Creek and nearby Dyes Inlet before and after bridge construction, reliable, verifiable, and accurate data will be collected. These data will be contributed to the State's Marine Water Quality Monitoring Program, the Clear Creek Trail Alliance, citizens of Kitsap County, and other parties interested in gaining knowledge concerning effectiveness of the restoration project. Comparison of data collected prior to and following construction will aid understanding of successful restoration features of the project. It will also assist in determining what and where adaptations are needed in the ongoing management of this revitalized ecosystem.

\section{Community Partner Needs}

The Clear Creek Trail Alliance (CCTA) is a non-profit organization focused on fostering stewardship opportunities for local citizens in Central Kitsap County, Washington. The group formed in 1993 to preserve riparian and open space alongside Clear Creek through 
establishment of the Clear Creek Trail. CCTA maintains 9 miles of trail, an interpretive center, and two additional covered meeting spaces and a community garden. CCTA also sponsors numerous events designed to engage people of all ages in outdoor activities (CCTA, 2016). Among the environmental education programs the group offers is the long standing "Salmon in the Classroom". Dedicated to elementary aged children, it provides an opportunity for Central Kitsap School District students to discover the life cycle of salmon using in classroom aquaria. During the two and half month program, students raise and observe the transition of salmon eggs into fry. During the winter months, beginning each January with the donation of chum salmon eggs from the Suquamish Tribes' Grover's Creek Hatchery, the school led curriculum introduces components of salmon habitat needs. The children monitor temperature and water clarity while the salmon grow from egg to alevin, then into fry. In March, students participate in a half day field trip to the confluence of the north and west forks of the Clear Creek where they plant trees and native shrubs, learn about water quality, view common macroinvertebrates of the area, and release the fry they have raised into the main stem waters (CCTA - SITC, 2016).

The development and implementation of this Clear Creek Estuary improvement project provides an opportunity for older students and local citizens to expand their knowledge of salmon habitat needs and learn about the benefits to salmon afforded through stream and estuary restorations.

The CCTA is working with local partners, such as Kitsap County Health Department, Kitsap Stream Stewards and Beach Naturalists, Kitsap Noxious Weeds, and Clean Water Kitsap to monitor the effects of the estuary restoration. The CCTA would like to gather data related to water quality, beach/bank elevations, vegetation in the vicinity, and invertebrate density using the estuary. The group is also interested in organizing work parties to remove invasive plant species remaining after the bridge project is completed. The CCTA hopes to engage local college students and senior citizens as citizen scientists throughout this process, by providing training in data collection related to the biological parameters and hands-on opportunities to gather data. The data collected before and after the bridge construction will be shared with state and local agencies with interest in Puget Sound restoration such as, Puget Sound Ecosystem Monitoring Program, the West Sound Watershed Council, Washington State's Marine Water Quality Monitoring Program, Clear Creek Trail Alliance citizens of Kitsap County, and other interested parties. Information will also be shared with the Kitsap County Community Council - the local governing body in Silverdale.

\section{Goals of this Project}

In response to the needs of CCTA, the goal of this project was to develop a monitoring program that would characterize water and habitat quality related to salmonid needs in the Clear Creek Estuary before, during, and after the Bucklin Hill Bridge Replacement Project. The parameters 
selected for the monitoring program were those known for being salmonid habitat indicators.

Overall Goals of the CCTA estuary monitoring include the following:

- Develop a monitoring program that will measure water quality, vegetation, invertebrate and sediment parameters before, during, and after the Clear Creek Estuary habitat restoration related to the bridge construction.

- Develop monitoring protocols that can be used by the CCTA, a nonprofit organization with a limited budget, utilizing citizen scientists.

- Establish baseline conditions of water quality, vegetation composition, invertebrate populations, and sediment profiles prior to the Bucklin Hill Bridge Replacement Project.

- Train volunteers in basic estuarine habitat monitoring methods.

- Provide volunteers with information on estuary management and restoration.

- Continue monitoring habitat conditions over 3 years using protocols that CCTA can complete.

- Contribute to the State's Marine Water Quality Monitoring Program.

- Educate residents in the watershed regarding salmon habitat to encourage pollution prevention and environmental stewardship.

- Employ (or apply) adaptive management techniques in the event goals of the restoration project are not met or assumptions were false.

This project will accomplish the first four activities:

- Develop a monitoring program for the CCTA;

- Develop monitoring protocols;

- Establish habitat conditions before the bridge project is started; and

- Train volunteers

\section{Methods}

Various physical characteristics can be utilized in gauging the suitability of an estuarine habitat for salmonid use. To evaluate the effectiveness of the Bucklin Hill Bridge replacement at improving salmon habitat, the following parameters will be measured: Water Quality, Sediment Composition and Elevation Profiles, as well as Invertebrates, and Vegetation species found in the area.

This project's monitoring plan is designed to identify whether trends in monitoring parameters indicate improvements to water quality and other parameters evaluated. Evidence may include signs of increased sediment transport into and out of the estuary. Sediment transport could provide more appropriate substrate for macro invertebrates, thus more prey for salmonids. To this end, preconstruction data were collected from April 2014 through September 2015 to establish a baseline from which to measure changes over time. Procedures follow recommendations in the Puget Sound Ecosystem Monitoring Program (PSEMP) Shoreline Monitoring Toolbox Protocols (Shoreline Monitoring Toolbox [SMT], 2014). 
The monitoring program was developed to ensure high quality data are collected to help to track estuarine water quality trends, sediment profiles, and types of macroinvertebrates found in the tidally influenced Clear Creek estuary. The monitoring was conducted by me and a core group of trained citizen scientists and guest volunteers.

\section{A. Training Data Collectors}

Participants included persons of a variety of ages, backgrounds, and experience such as students, the actively employed, and retirees. Volunteers were provided with a annotated sample of the data collection worksheet used monthly during water quality monitoring. The handout provided a preview of the parameters of interest and a description of their purpose (See appendix A). A pre-collection day training session was held to provide an understanding of the methods of data collection. Data was collected onsite in a group effort. More experienced data collectors guided new volunteers in collecting and recording physical and chemical site data. Some samples, such as those related to nitrogen concentrations (total ammonia, nitrates, and nitrites) were processed in situ to reduce denitrification prior to analysis. Other samples were processed upon return to the provisional lab set up at the Sa'qad Interpretive center. Hands on guidance and step-by-step procedural handouts were used in performing chemical analysis (see Appendix B - Clear Creek Estuary Monitoring Volunteer Training Manual).

\section{B. Monitoring Site Descriptions}

There were four locations selected for observation and data collection. Field locations attempt to characterize the tidally influenced areas of the estuary of Clear Creek/Dyes Inlet (Figure 11). Two sites were selected, south of the existing Bucklin Hill Bridge, which have more marine environmental characteristics (Site 1 and Site 2). The other two sites, with more estuarine features (Site 3), located north of the bridge (Site 4), were also chosen for monitoring to access changes in estuary portion of Clear Creek. By collecting extended term water quality data from four points along the continuum from Old Mill Park to the top edge of the salt marsh where the tidal influence is expected to diminish, we can obtain a full characterization of water quality conditions of that portion of the watershed. 


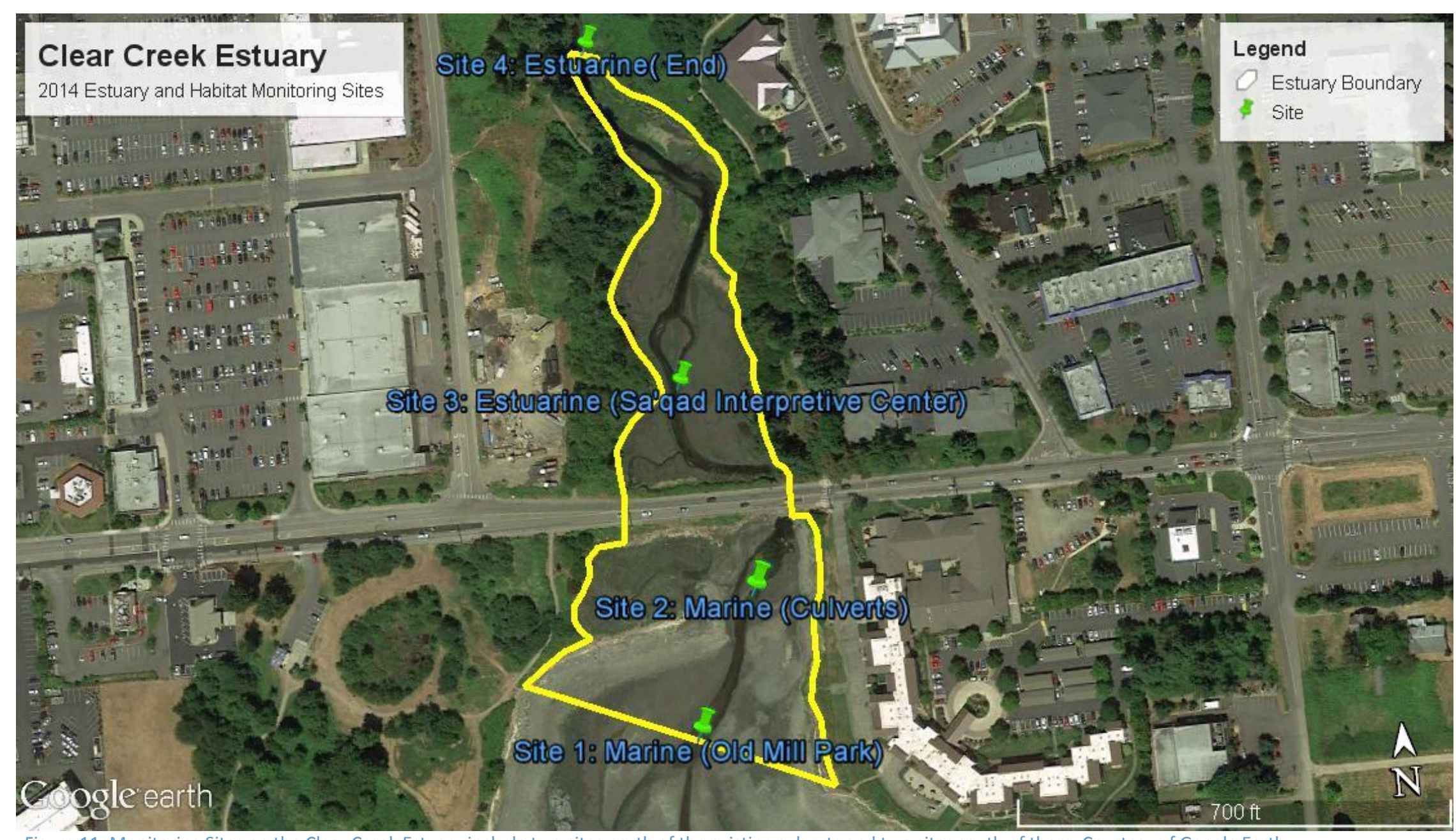

Figure 11: Monitoring Sites on the Clear Creek Estuary include two sites north of the existing culverts and two sites south of them. Courtesy of Google Earth.

27 Clear Creek Estuary Restoration: Establishing a Monitoring Program and Baseline Conditions CBM 6/28/2016 
Site1 - Old Mill Park (Marine): The first sampling site lies $118.2 \mathrm{~m}$ south and westerly of the Bucklin Hill Bridge culverts. It represents the southern extent of the Clear Creek Estuary. The bankful width of this site was $161.8 \mathrm{~m}$. The wetted width ranged from $3 \mathrm{~m}$ to the full bankful width as it varied with the diurnal tides. Moving from east to west, the bank above the MHHW was not armored and showed signs of slow erosion-probably slowed by the dense vegetation. Large woody debris tended to accumulate at this angular point. The rocky shoreline slopes $2 \%$ from the bank to thalwag. Cobble remained the predominate substrate to LHHW at which point acorn barnacle (Balanus glandula) encrusted pebble, fine sand, and mud began to predominate. These sediment compositions were present in reverse order over a $3 \%$ rise in elevation from thalwag to $\mathrm{MHHW}$. There the gravelly cobble transitioned to sand on western bank. The shoreline of the site was characterized by low growing marine tolerant species of plants such as perennial saltwort (Salicornia virginica), gumweed (Gridelia integrifolia), silver burweed (Ambrosia chamissonis), jaumea (Jaumea carnosa. Common invertebrates included native graceful crab (Metacarcinus gracilis), littleneck clams (Leukoma staminea) and invasive dog whelks (Nucella lapillus). A variety of shorebirds utilize the beach, particularly Greater yellowlegs (Tringa melanoleuca). Diving ducks, such as buffleheads (Bucephala albeola) frequent this site as well.

Site 2 - Old Mill Pond (Marine): This location was 42 meters south and slightly west of the embankment built for the old Bucklin Hill Bridge. The bankful width was $44.02 \mathrm{~m}$. The wetted width ranged from $8.26 \mathrm{~m}$ to the bankful width as it varied with the diurnal tides. The stream split into two channels $22 \mathrm{~m}$ north of this site and returned to a single streamflow $7.7 \mathrm{~m}$ south of it. The substrate of both channels was composed of mid-sized cobble with little silt matrix. The eastern bank was dominated by large to mid-sized cobble interspersed with coarse sand with an averaged $8 \%$ slope to the $4.8 \mathrm{~m}$ eastern channel. The $4.2 \mathrm{~m}$ wide "island" substrate was composed of silt, coarse sand, and mid-sized cobble. The western channel was narrower at $3.5 \mathrm{~m}$. The bank rises $3 \%$ to the west of the site. One meter above and west of the thalwag were delineated wetlands surrounding an old mill pond filled with fine silt sediment ("the lagoon"). Marine tolerant plants, similar to Site 1 line the north, south, and western edges. Sea plantain (Plantago maritime ssp. juncoides) was found along the western edge of the lagoon in greater abundance than other locations. This site was frequented by flocks of killdeer (Charadrius vociferous).

Site 3 - Clear Creek Estuary (Estuarine): The third site lies 71.9m directly northwest of the embankment and $84.03 \mathrm{~m}$ following the stream bed. The bankful width was 
$52.1 \mathrm{~m}$. The wetted width ranged from $6.2 \mathrm{~m}$ to the bankful width as it varied with the diurnal tides. Diurnal tidal inundation occurs except at lowest tidal extremes. The creek traveled through a broad, mostly flat expanse of fine sand and silt deposition. The stream flowed $44 \mathrm{~m}$ from the eastern bank, across silt covered, yet visible small to mid-sized cobble. Its path was southerly through an incision in the western quarter of the "flat." A large bend changed the course of the stream to eastward before it entered the culverts located in the eastern end of the bridge fill. Moving from east to west, the east bank contained a narrow strip of the closest delineated estuarine wetland. Several small "islands" of S.virginica sat atop the eastern portion of the mud flat $12.2 \mathrm{~m}$ from the bank. These patches extended east to west for $23 \mathrm{~m}$. The immediate western bank covered $11 \mathrm{~m}$ west and 0.5 meters above the stream. It had little to no cobble and was a mudded shelf that became more distinctly as the creek began to curve. The western curve and along the berm was also a delineated wetland. The landscape above the shelf predominately contained plants such as Lyngbye's sedge (Carex lyngbyei), Douglas's aster (Aster subspicatus), and Nootka rose (Rosa nootka) behind which grow large Douglass Fir (Pseudotsuga menziesii) and Western Red Cedar (Thuja plicata). Great blue heron (Ardea Herodias), green-winged teals (Anas crecca), and bald eagle (Haliaeetus leucocephalus) have been observed at this site. Scuds or amphipods (Gammaridean amphipoda) were common to this section of the estuary.

Site 4 - Clear Creek (Estuarine-Freshwater): This site was furthest from the planned construction zone and the most riverine. It lay north and westerly, directly upstream $252.8 \mathrm{~m}$ from the culverts. The streambed path measure to the culverts was $291.9 \mathrm{~m}$. The average stream bankful width measured $4.9 \mathrm{~m}$ and tidal bankful width was $10.4 \mathrm{~m}$. This site was not always inundated by tidewater. Except during extreme low tides, the saltwater toe would reach this location. Moving from east to west, the eastern bank supported dense shrubs and smaller trees, often remnant fruit trees from the period when the upland use was agricultural in nature. Continuing east $1 \mathrm{~m}$, over a $0.5 \mathrm{~m}$ depression, the soil was often nearly saturated and without vegetation. Over the next $4 \mathrm{~m}$ it was densely vegetated with salt marsh grass (Distichlis spicata), Lyngbye's sedge (Carex lyngbyei), and sea arrow-grass (Triglochin maritimum). The bank dropped $1 \mathrm{~m}$ to pebbled beach and often the stream's edge. The stream bed contained medium to small cobble, coarse sand, and some silt. The western bank rose $3.1 \mathrm{~m}$, nearly vertically above the stream. The stream bed is well shaded by large trees. Some land sliding from the bench above the stream contributed large woody debris to the stream over the study. Song birds 
such as black-capped chickadees (Poecile atricapillus) and American robins (Turdus migratorius) were common at this site.

\section{Parameters, Collection and Processing Procedures}

Monitoring to establish baseline conditions began in April 2014, slightly more than one year prior to construction activities. Ongoing monthly and annual baseline collections continued up to the date construction began, in July 2015. Water samples were collected and analyzed monthly to determine chemical and physical conditions. Budgetary limits of CCTA resulted in the selection of Hanna Instruments Marine Science Educational Kit to support measurement of chemical properties in the stream. Other measures in the estuary included summer sampling of macro benthic invertebrates/ epibenthic invertebrates to determine whether aquatic food sources were found in the stream and on the shore, plant community diversity surveys to identify whether riparian shading and large woody debris supplies or invertebrate food sources where provided along the shoreline, as well as fall sediment composition and elevation profiles to capture changes in the shoreline that might result from increased tidal movement of sediments [table 11].

Table 11: The Monitoring Schedule of Clear Creek Estuary is dependent upon the measurement factor. Parameters included elevation profiles to capture changes in the nearby shore that may result from increased tidal movement of sediments, invertebrate types and numbers as food sources for salmon, sediment composition and profile suitability as habitat substrate, vegetative communities as protection for salmon or food for invertebrates, and the quality of the physical and chemical characteristics of the water body.

\begin{tabular}{|l|l|l|}
\hline Parameter & $\begin{array}{l}\text { Sampling } \\
\text { Schedule }\end{array}$ & Location \\
\hline Elevation Profiles & Annually* & Bankful width transect across sites 1-4 \\
\hline Invertebrates & Annually* & $\begin{array}{l}\text { In stream, MLLW and MHHW every } 22 \text { meters along an } 88 \mathrm{~m} \text { transit } \\
\text { on both sides of shoreline }\end{array}$ \\
\hline Sediment Composition & Annually & Every 3 meters along the bankful width transect of sites 1-4 \\
\hline Vegetation & Annually & $\begin{array}{l}\text { Every } 22 \text { meters along an } 88 \mathrm{~m} \text { transit on both sides of shoreline } \\
\text { beginning at 22m south of each site. }\end{array}$ \\
\hline Water Quality & Monthly & Thalwag of stream at sites 1-4 \\
\hline
\end{tabular}

*Some parameters measured annually in the baseline study will be assessed semi-annually after construction begins.

The practical constraints to collecting monthly and annual data on the originally scheduled date were due to safety concerns such as extremely high tides and equipment failure. In the case of extreme high tides an alternative day was selected that was as close to the scheduled day as possible. In the event of equipment failure, data was collected as soon as the equipment was repaired.

\section{Water Quality Monitoring:}

To assess the chemical and physical parameters of water quality, measurements were taken monthly. Parameters included regulated water quality indicators and those that 
do not have concentration limits established by legislation (WAC 173-201A, 2006). Parameters consisted of temperature, $\mathrm{pH}$, dissolved oxygen, conductivity/ total dissolved solids, metals, nutrients, specific density, and salinity [table 12]. Local restoration monitoring programs, such as conducted at Carpenter Creek/Appletree Cove (Palmer, et al., 2004) and the EPA Volunteer Stream Monitoring: A Methods Manual (EPA, 2007), outline the value of collecting similar data when measuring habitat characteristics.

Table 12: The water quality monitoring parameters of Clear Creek Estuary included indicators with and without Washington State water quality standards (WA WQS). Chemical compound concentrations were generally measured as milligrams per liter ( $\mathrm{mg} / \mathrm{L})$. Conductivity was measured in micro-Siemens per centimeter $(\mu \mathrm{S} / \mathrm{cm})$ which is equivalent to the $\mu \mathrm{mhos} / \mathrm{cm}$ referenced in WA WQS. Totals dissolved solids and salinity units were part per thousand (ppt). Flow was measured in cubic feet per second (cfs). Temperature was measured using the Celsius scale $\left({ }^{\circ} \mathrm{C}\right)$. $\mathrm{pH}$ is a unit-less measure therefore none were assigned.

\begin{tabular}{|l|c|l|c|}
\hline Parameter & WA WQS? & Parameter & WA WQS? \\
\hline Acidity/ Alkalinity (ANC) in $\mathrm{mg} / \mathrm{L}$ & No & Metals $\left(\mathrm{Cu}^{+}, \mathrm{Zn}^{+}\right.$) in $\mathrm{mg} / \mathrm{L}$ & Yes \\
\hline Conductivity in $\mu \mathrm{mhos} / \mathrm{cm}=\mu \mathrm{S} / \mathrm{cm}$ & No & pH (unit-less) & Yes \\
\hline Flow in cfs & No & Salinity in ppt & No \\
\hline Dissolved Oxygen (DO) in $\mathrm{mg} / \mathrm{L}$ & Yes & Temperature in ${ }^{\circ} \mathrm{C}$ & Yes \\
\hline $\begin{array}{l}\text { Nutrients }\left(\mathrm{NH}_{3} / \mathrm{NH}_{4}{ }^{+}, \mathbf{N O}_{2}{ }^{-}, \mathbf{N O}_{3}{ }^{-}, \mathbf{P O}_{4}{ }^{3-} \text { ) in }\right. \\
\text { mg/L }\end{array}$ & No for lotic systems, Yes for $\mathrm{PO}_{4}{ }^{3-}$ in lentic systems \\
\hline Total Dissolved Solids (TDS) in ppt & \multicolumn{4}{l}{} \\
\hline
\end{tabular}

\section{On Site Analysis}

A grab water sample was collected in-stream at the point where the thalwag and crossstream transect intersected and midpoint depth of the water column. On site chemical analysis of compounds in milligrams/liter $(\mathrm{mg} / \mathrm{L})$ included colorimetric analysis of nitrogen concentrations (total ammonia, nitrates, and nitrites) and stabilizing the dissolved oxygen concentration in the sample via a modified Winkler process for later in lab titration using Hanna Instruments reagents. Several measurements such as air and water temperatures, $\mathrm{pH}$, electrical conductivity (EC), and total dissolved solids (TDS) were collected using Hanna Instruments hand held digital probes at each of the four sampling sites. Temperature and $\mathrm{pH}$ levels were collected using a model HI-98127 digital probe. Temperatures were measured using the Celsius scale $\left({ }^{\circ} \mathrm{C}\right)$. The $\mathrm{pH}$ scale representing the negative logarithm of hydrogen ion concentration in an aqueous solution is unit-less, therefore none were assigned. To collect EC and TDS, a model HI 98312 digital probe was used. EC was measured in microSiemens per centimeter $(\mu \mathrm{S} / \mathrm{cm})$ which is equivalent to micromhos $(\mu \mathrm{mhos} / \mathrm{cm})$, the unit referenced in WA WQS. TDS was measured in parts per thousand (ppt).

Physical measures related to flow were collected. Stream widths were measured at the beginning and end of a 20 foot long transect. In addition, stream depths were recorded 
at three locations in the stream, at both ends of the 20 foot transect. Depth measurements were made at the eastern, center, and western thirds of the water's width. The length of time required for a float to travel down the length of transect was also recorded. These three physical characteristics are used later in estimating flow rate for the stream segment in cubic feet per second (cfs).

The physical characteristics of streamflow represent the stream's sediment carrying power (capacity). The method used captured mainly surface flow. Water volume measurements were collected within 2 hours of low tides using the EPA Volunteer Stream Monitoring methods. Cfs flow was calculated as the average cross-sectional area of the stream $\left[A=\left(T_{1} \mathrm{ft}^{2}+\right.\right.$ $\left.\left.\left.T_{2} f t^{2}\right) / 2=A f t^{2}\right)\right]$ multiplied by the length of the stream reach $(L=$ $20 \mathrm{ft}$ ) multiplied by a coefficient (correction factor $C$ that accounts for the substrate surface) resulting in a volume calculation for that quadrant or transect. The volume was divided by the time for a float to travel the stream length $(T=$ seconds). Factor $A$, the

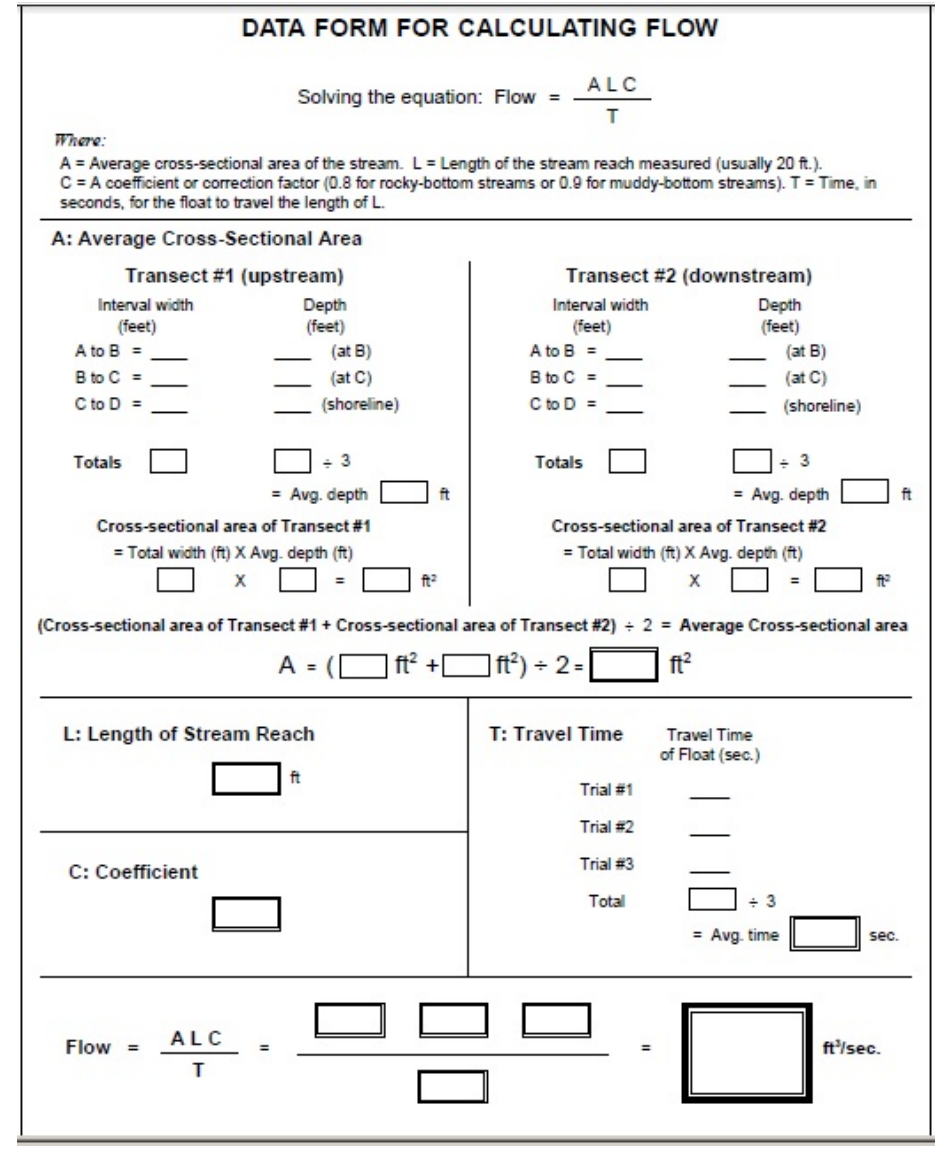

Figure 12: Data Form for Calculating Flow, modified from EPA Volunteer Stream Monitoring: A Methods Manual, Data Form for Calculating Flow uses a standard stream segment length, captures the average area of the section, and the length of time for a float to traverse the segment to estimate stream flow in cubic feet per centimeter (cfs) quadrant area, was computed from the average of depth measurements taken at three placements within the stream (eastside, westside, and center of the stream) and the distance across the stream at the beginning of the 20 foot transect $\left(T_{1}\right)$ and the at the end of that transect $\left(T_{2}\right)$. The $T_{1}$ and $T_{2}$ values were added together, divided by two, then multiplied by the length of the reach and the applicable streambed coefficient $(C=$ 0.8 for rocky substrates and 0.9 for muddy bottoms). The result was divided the amount of time $(T)$ an object to traverse the reach which provided the flow calculation or velocity (EPA, 1997), [figure 12]. 


\section{In Lab Analysis}

Water samples were transported to the provisional lab in sealed plastic or glass bottles then processed generally within two hours of collection. Acidity, alkalinity, carbon dioxide $\left(\mathrm{CO}_{2}\right)$, dissolved oxygen (DO) in milligrams/liter $(\mathrm{mg} / \mathrm{L})$, and salinity in parts per thousand (ppt) concentrations were measured using Hanna Instruments buffering solutions and titration methodologies. Colorimetric assay analyses using Hanna Instruments reagents were performed on phosphates $\left(\mathrm{PO}_{4}\right)$, copper $\left(\mathrm{Cu}^{+}\right)$, and zinc $\left(\mathrm{Zn}^{+}\right)$to calculate $\mathrm{mg} / \mathrm{L}$ concentrations in the water samples. Copper and zinc testing through the use of reagents began in 2015. Therefore, prior to direct chemical analysis, $\mathrm{pH}$ levels were employed as a reasonable proxy for direct metal monitoring. This approach did not provide concentration levels, however in both saltwater and freshwater, a more neutral pH level indicates that zinc and copper are less soluble and therefore less available to influence biological forms (Lenntech, 2014, du Bray, 1995).

\section{Sediment Characteristics and Profiles}

Sediment size and composition affects the types of insects, invertebrates, and the frequency in which spawning fish use the area. This in turn affects the food supplies available to salmonids. To characterize the surface sediment of the shoreline near each monitoring site, quadrats measuring $0.5 \mathrm{~m}^{2}$, were used to categorize surface sediments. Photographs were taken every three meter along a transect line that intersected the monitoring site location. The photos assist in making a visual estimate of the percentage of cobble and fines present at the survey sites. Surface sediments were classified by size, using visual estimations for stones and touch for fines. Classes used were cobble $(>6 \mathrm{~cm})$, pebble $(4 \mathrm{~mm}-6 \mathrm{~cm})$, granule $(2-4 \mathrm{~mm})$, sand ("gritty" up to $2 \mathrm{~mm}$ ), and silt/clay (smooth between fingers). This process follows Shoreline Monitoring Toolbox Protocols for sediment size with two modifications: sample locations were perpendicular to the wrack line versus parallel and more frequent assessments were made (SMT, 2014).

Using direct leveling survey techniques, a surveyor's sighting (optical) level and a stadia rod combination where employed to document the elevation profile along an east to west transect line that intersected each monitoring site (Brinker, et al., 1995). This method allowed establishment of the vertical (longitudinal) elevation values of the stream, shoreline, and bank. A survey was completed at each of the monitoring sites along cross stream transects in three meter intervals, except at site 4 where the measurements were taken in one meter increments to improve granularity. 


\section{Vegetation Surveys}

Annual vegetation surveys were made in late spring/early summer to ascertain community composition at each of the monitoring sites. Along an $88 \mathrm{~m}$ transect, running parallel to the stream and above $\mathrm{MHHW}$, a quadrat, measuring $0.5 \mathrm{~m}^{2}$, was used to record the plants present within the square. All plants within the quadrat were recorded with predominant species noted by their greater percentage of cover. Information was collected every $22 \mathrm{~m}$ on each side of the stream. Photographs were taken at each quadrat placement to assist in identifying plants present in the quadrat and near the sampling sites. This process follows Shoreline Monitoring Toolbox Protocols for vegetation (SMT, 2014). In addition, riparian tree vegetation cover was estimated at site 4 using a densitometer. Consultant resources provided by Kitsap County Beach Naturalists and Native Plant Advisors were garnered to ensure accurate identification of native and invasive species located within the ecosystem.

\section{Invertebrate Sampling}

An annual invertebrate and insect sampling in the stream and along transects parallel to the shoreline was completed in late spring. The methodology used was similar to that used for benthic invertebrate sampling in the Nisqually Estuary Invertebrate Sampling program (Nisqually, 2010).

Invertebrate sampling was completed at each of the four the monitoring sites. Kick nets were utilized for in-stream sampling of benthic invertebrates. Glass bottles were used to collect in water column samples at locations with muck substrate. Pit traps were used for shoreline sample collection. The pit traps were placed at four locations along an $88 \mathrm{~m}$ transit that runs parallel to the streambed at the Mean Lower Low Water (MLLW). This process was repeated at Mean Higher High Water (MHHW) (wrack line) and on each side of the stream.

All samples were stored in a 99\% isopropyl alcohol or $95 \%$ ethanol solution during transport. In laboratory identification was completed at Olympic College - Poulsbo Campus. Monocular Compound microscopes and invertebrate keys such as Stream Insect of the Pacific Northwest (Edwards 2008) and Oregon estuarine invertebrates (Rudy, et al., 1983) aided taxonomic identification to at least the family level. Samples that were not completely analyzed were stored in alcohol/ethanol preservative solution in the onsite deep freezer for a maximum of 4 months (Dawson et al., 1998). 


\section{Beach Seining}

Fish such as surf smelt and shiner perch support dietary needs of outward migrating salmon. The program included up to three beach seines per year, during the late spring and summer months, to catalog marine fish species inhabiting the nearshore of Dyes Inlet at nearby Old Mill Park. This component of the monitoring was done in coordination with ongoing data collection by local volunteer fish biologists and the Suquamish Tribe. At high tide, a 100 foot net was set approximately 50 feet offshore and hauled in manually by volunteers on the beach. Collected samples were identified for species, measured for length, and recorded onto datasheets for subsequent entry into a database managed by the Suquamish Tribe Fisheries Department. Samples were returned unharmed into nearshore waters.

\section{Results}

\section{Water Quality}

The chemical analytics performed included measures of 17 water quality factors. Washington State has approved Water Quality Standards (WA WQS), promulgated in Chapter 173-201A WAC, 2006, for temperature, dissolved oxygen (DO), pH, metals such as copper and zinc $\left(\mathrm{Cu}^{+}, \mathrm{Zn}^{+}\right)$, nutrients - specifically phosphates $\left(\mathrm{PO}_{4}\right)$ in lentic systems, and fecal coliform bacteria (FC). Measured values were compared to the applicable seasonal requirements of WA WQS. For the parameters with no state water quality standards, descriptive statistics (mean, standard deviation and range) were calculated for the two seasonal groupings [Appendix D]. Seasonal groupings were "Winter" which include October through May data and "Summer" comprised of data collected in June through September. No zinc or copper metals were detected in the sampling; therefore these components are excluded from this report. As discussed earlier, FC data were not collected in this project; therefore this parameter is not part of the results set. The estuary is a lotic system and therefore WA WQS cannot be applied to the nutrients samples collected. For this reason nutrient data were analyzed in the manner of parameters without WA WQS. The results for ammonia and phosphates are shown in Appendix D. Nitrates and nitrites concentrations were below detection limits.

Salinity - Vertical depth averages collected over a 365 day period determine which of the use criteria (fresh water or marine) are applicable to a water body. In this project, data were collected monthly from April 2014 through September 2015. Samples were taken most frequently during low tides where vertical depths were commonly less than $1 \mathrm{~m}$. Sampling during high tides, particularly at Site 1 and 2, captured surface water samples (summer season of 2014). Therefore those data may not fully portray salinity values in the deeper waters below. As expected, salinity levels are highest at Site 1 and 
lowest at Site 4. For sites 1, 2, and 3 the percentage of samples with salinity values greater than 1 part per thousand (ppt) over a 17-month period (or 12) results in marine water Aquatic Life Use categorization. For Site 1, 56\% of the samples had values greater than 1ppt. At Site 2 and at Site 3, more than 5\% of the samples had greater than 1ppt salinity (43.8\% and 5.9\%, respectively). At Site 4 , salinity results indicate that the application of freshwater use criteria is appropriate since none of the samples had a salinity reading greater or equal to 1ppt [figure 13].

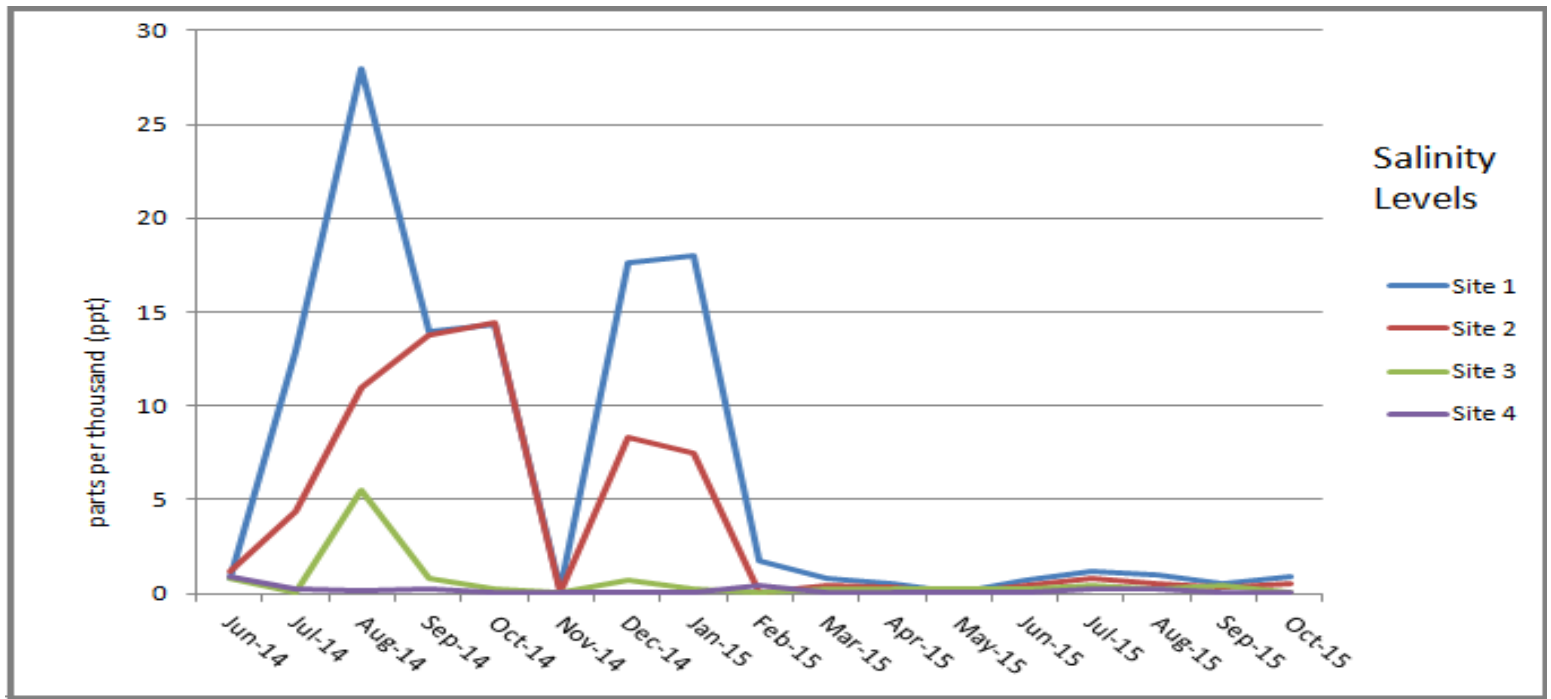

Figure 13: Salinity in parts per thousand (ppt) for all monitoring sites over a 17 month period. Sites 1-3 salinity results demonstrate more than $5 \%$ of the samples have a concentration of 1 ppt or greater which result in the application of marine water standards. All Site 4 samples have concentrations less than 1 ppt therefore

freshwater use standards apply.

pH levels were generally in the extraordinary to good range (7.0 to 8.5), which is a Washington State water quality designation for marine waters, however several measurements during the summer were outside the "fair" range (6.5 to 9.0). Of particular note are the excursions at sites 1-3 in June and July of 2015 where $\mathrm{pH}$ values ranging from 9.2 to 9.7 were recorded. Observational data noted a die-off of more than 30 graceful crabs (Metacarcinus gracilis) at sites 1-2 on each of these monitoring dates. High $\mathrm{pH}$ values were also recorded at Site 4 in the same time frame of 2015. The lower allowable value for $\mathrm{pH}$ is 6.5. The ceiling for freshwater aquatic use standards is 8.5, however $\mathrm{pH}$ readings were 8.9 and 8.8 for June and July, respectively [figure 14]. 


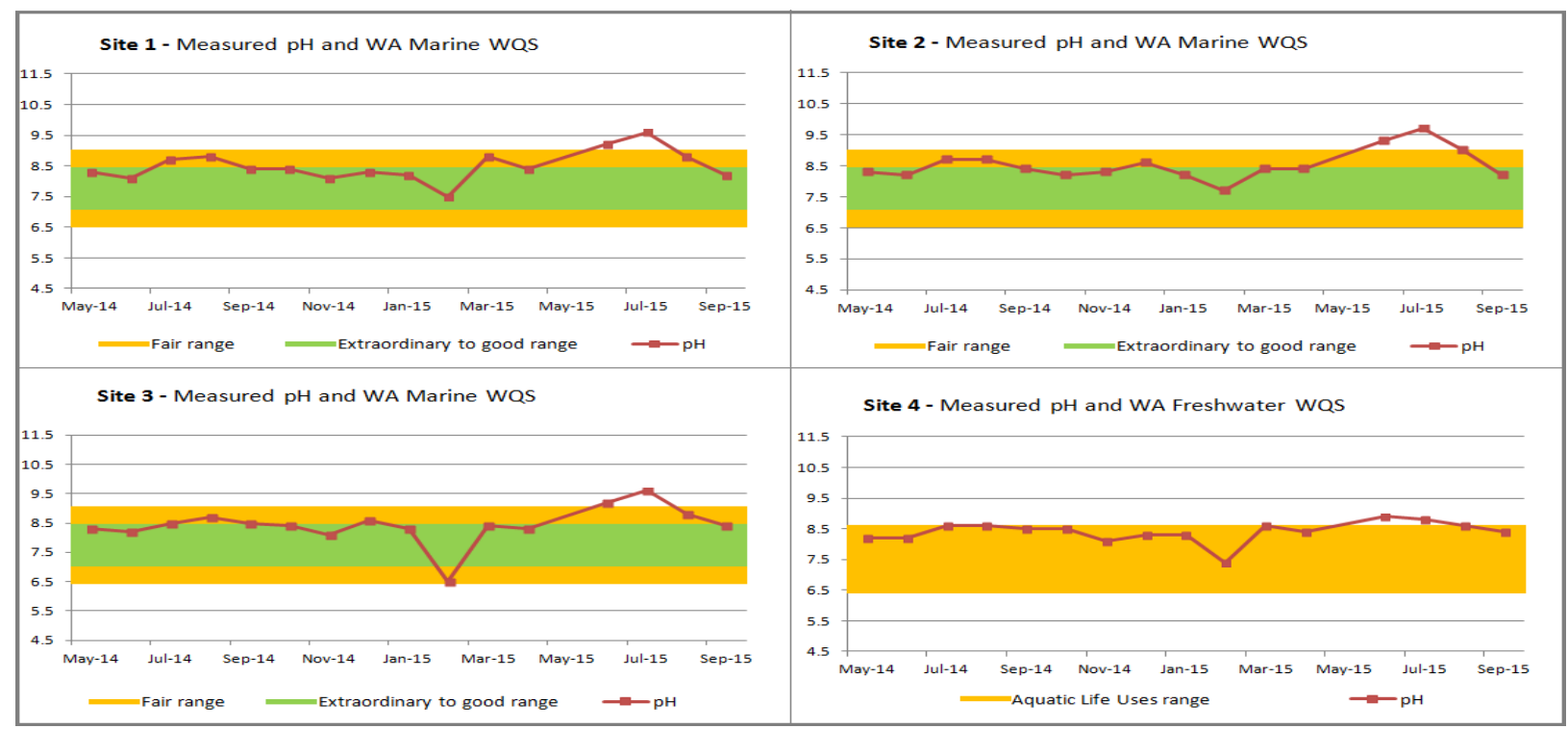

Figure 14: Collected pH values at Sites 1-4 are compared against Washington State Water Quality Standards for $\mathrm{pH}$. There are two categories for marine waters: "Extraordinary values to good levels" range from 7 to 8.5. "Fair" $\mathrm{pH}$ levels range from 6.5 to 9. Although there are two freshwaters groupings, the ranges are both 6.5 to 8.5. Excursions occurred in June and July 2015 at all sampling locations.

Dissolved Oxygen samples collected over the baseline project period generally indicate adherence to Washington water quality standards (WA WQS) at good quality or higher rating for marine waters [5mg/L or more]. Exceptions exist at sites 1 and 2 during summer months. At Site 1, the August 2014 sample analysis produced a concentration of $4.8 \mathrm{mg} / \mathrm{L} \mathrm{DO}$ which is of fair quality by marine standards [figure 15]. This sample was collected in the late afternoon (4:16pm), 58 minutes before the second daily low tide. At Site 2, the July 2015 sample had a DO concentration of $4.6 \mathrm{mg} / \mathrm{L}$, also indicating only fair quality [figure 16]. This sample was collected at 12:40pm, 1.26 hours prior to the low tide. Site 3 DO samples are generally excellent quality or better [figure 17]. Based on average salinity, Site 4 falls under Freshwater Uses. At site 4, nearly all samples demonstrate DO concentrations lower than the minimum standards for Freshwater Uses except for during the "Salmon Rearing and Migration Only" periods [figure 18]. 
Site1- Measured Dissolved Oxygen Comparison to WA 1-day Minimum for Marine Waters

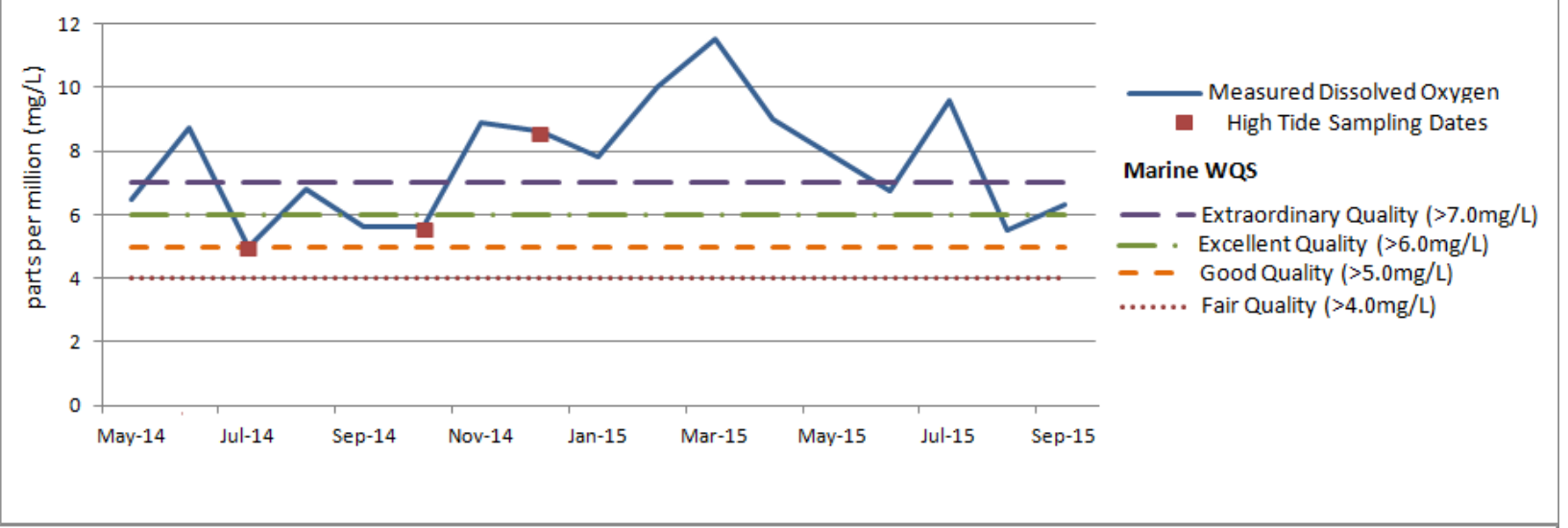

Figure 15: Site 1 Dissolved Oxygen (DO) versus Washington marine water quality standards shows collected data equate to "good to above extraordinary" concentrations except in August 2014 where DO levels dipped below 5mg/L and into the fair quality range.

Site2- Measured Dissolved Oxygen Comparison to WA 1-day Minimum for Marine Waters
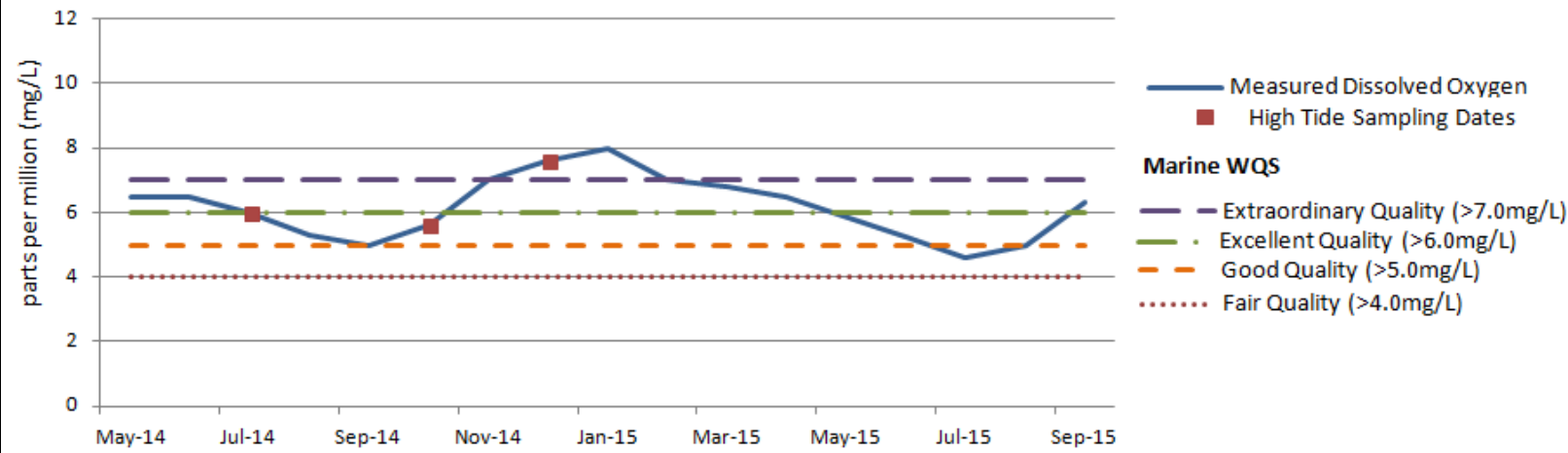

Figure 16: Site 2 Dissolved Oxygen (DO) versus Washington marine water quality standards shows collected data equate to "good to above extraordinary" concentrations except in July 2015 where DO registered below 5mg/L and therefore was of "fair quality".

Site 3- Measured Dissolved Oxygen Comparison to WA 1-day Minimum for Marine Waters

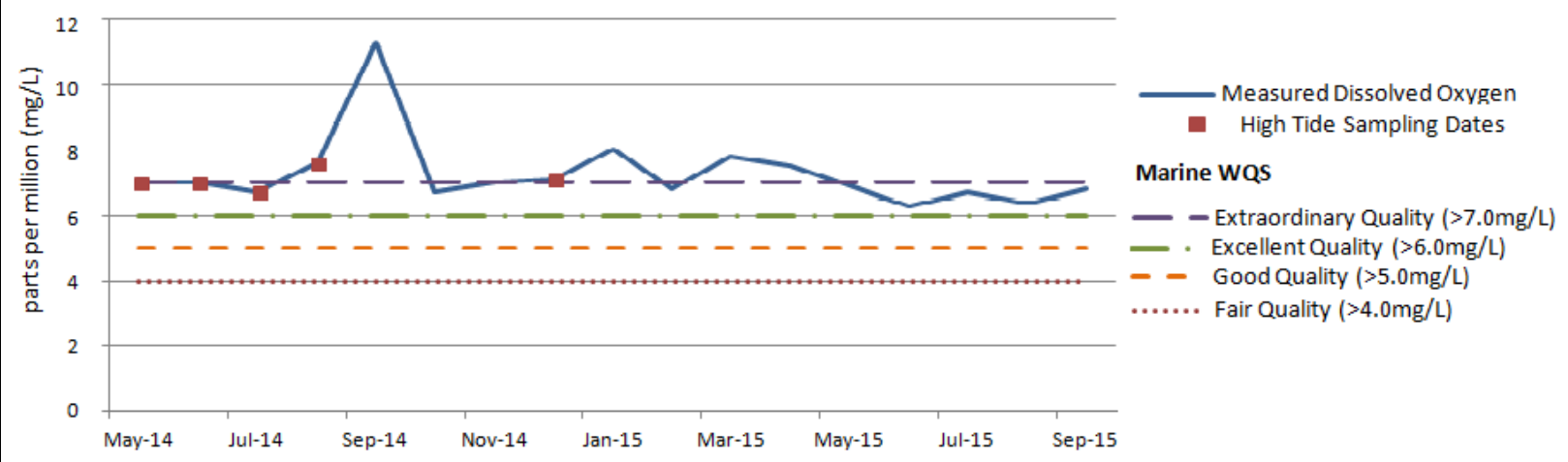

Figure 17: Site 3 Dissolved Oxygen concentrations versus Washington marine water quality standards data were found to be in the 
"excellent" or greater category, except in August 2014 when the level dips into the "good" quality range at less than 6mg/L.

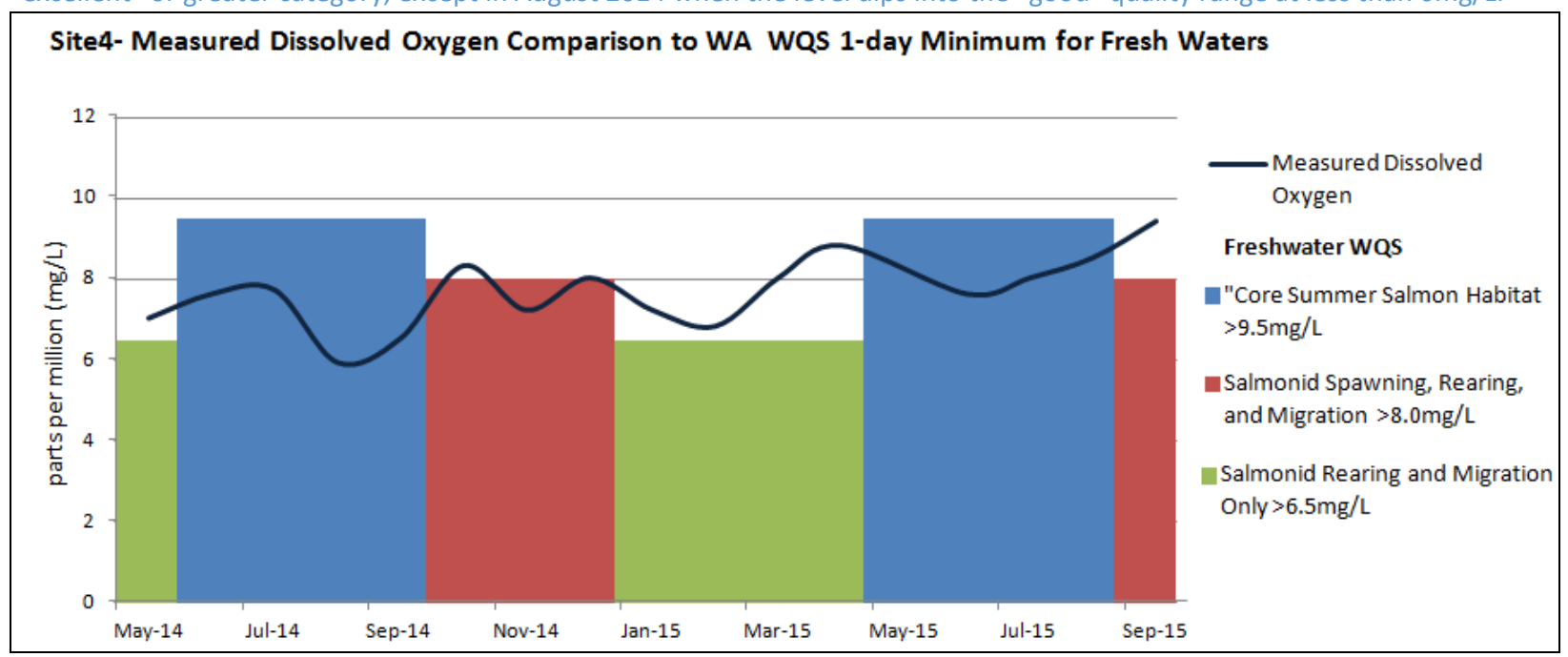

Figure 18: Site 4 Measured dissolved oxygen (DO) versus Washington fresh water quality standards show adherence to guidance for Salmonid rearing and migration only periods, however they were frequently found to be lower than the 1-day minimum guideline during Core Summer Salmon Habitat as well as during Salmonid Spawning, Rearing, and Migration use category periods.

\section{Temperatures}

Marine standards set guidance limits for maximum allowable temperatures as "1-day maximum temperature or 1-DMax" collected as instantaneous or continuous recordings. Freshwater guidance calls for recording the arithmetic mean of a 7 consecutive daily maximum temperature sampling, the "7-DMax." Instantaneous water temperatures taken at Sites 1-3 were compared to WA WQS Marine Use criteria based on salinity results. Site 4 is compared against WA WQS Freshwater Use values, also based on sampled salinity results. As with DO concentrations, Site 1 demonstrated excursion from WA WQS. Temperatures during August of 2014 and 2015 reached more than $22^{\circ} \mathrm{C}$ [figure 19]. Sites 2 and 3 remained within acceptable limits [figures 20 and 21 , respectively]. Site 4 also exceeded standards during the summers of 2014 and 2015 by reaching temperatures above the maximum of $16^{\circ} \mathrm{C}$ for Core Summer Salmonid Habitat in fresh water [figure 22]. This value was a 1-day maximum versus a 7-DMax value. 


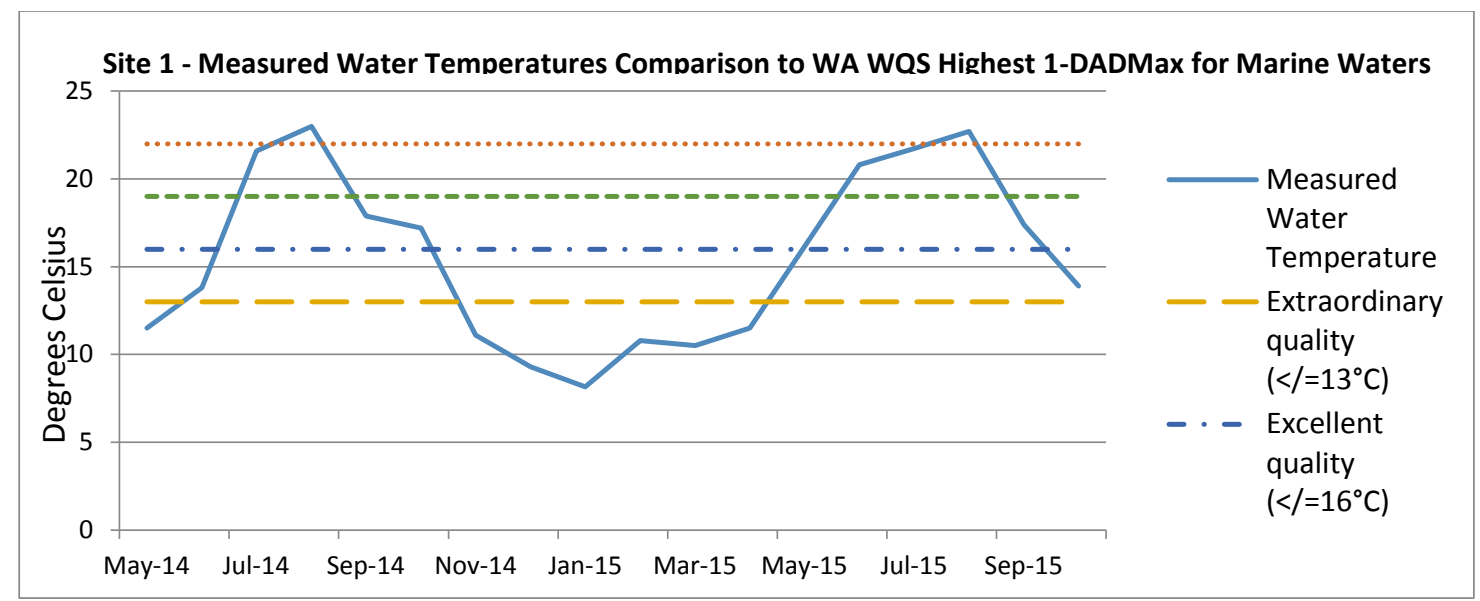

Figure 19: Comparison of measured temperatures to Washington State Water Quality Standards for Marine water at Site1 reveal a pattern of higher temperatures in summer and lower in winter months. Temperatures are generally of "good quality' or better, however excursions occurred in August 2014 and 2015 when measured water temperatures exceeded $22^{\circ} \mathrm{C}$.

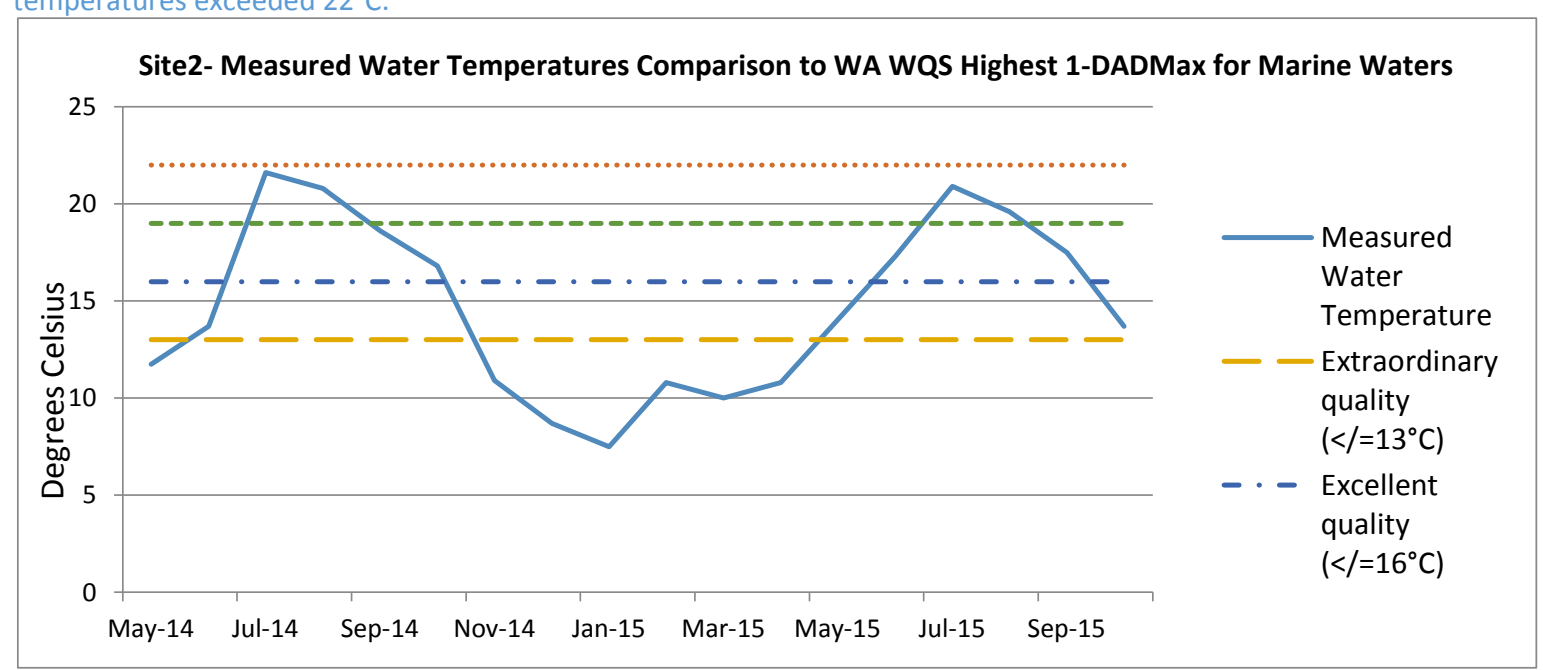

Figure 20: Comparison of Measured Temperatures to Washington State Water Quality Standards for Marine water at Site2. Standards are met year round for at least a fair quality rating.

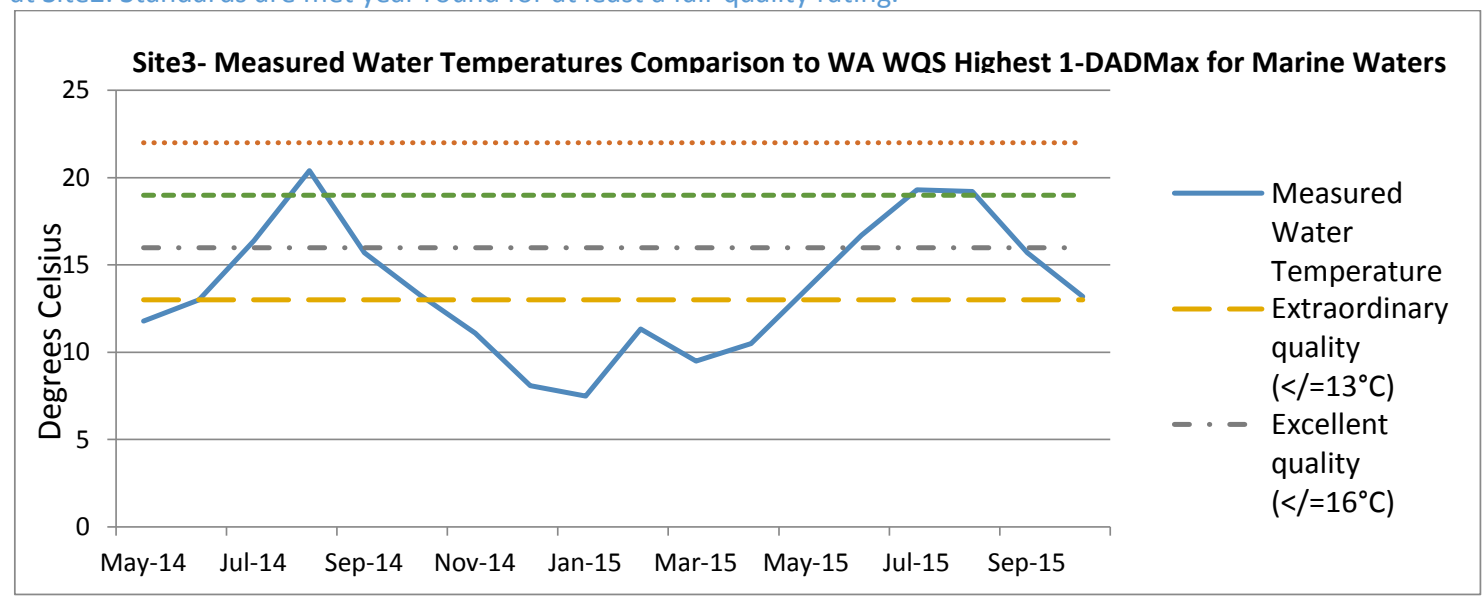

Figure 21: Comparison of Measured Temperatures to Washington State Water Quality Standards for Marine water at Site3. Standards are generally good quality or better. A fair quality rating would apply in July 2014 and 2015 


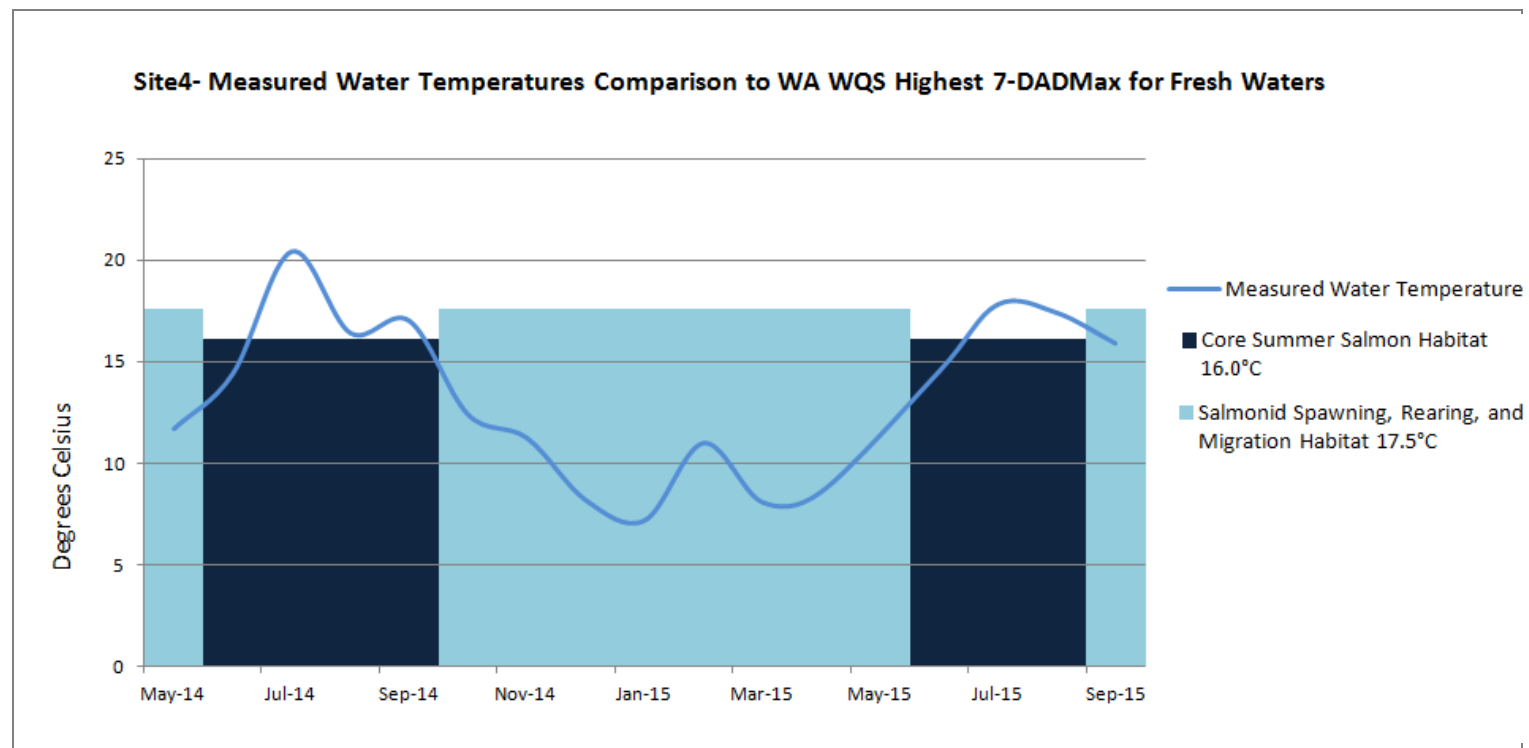

Figure 22: Comparison of Measured Temperatures to Washington State Water Quality Standards for Freshwater water at Site4. Excursions occur during July of 2014 and 2015 and in August 2014 when temperatures exceed $16.0^{\circ} \mathrm{C}$, however this was a single day data collection versus a week long data collection maximum.

\section{Flow}

The methods used captured mainly surface flow and illustrate moderate flow rates with seasonal differences in capacity from June 2014 through October 2015. Measures of the streams carrying capacity generally indicate low to moderate power to transport silt from fresh to marine waters. Flow rates were predictably higher during winter months and generally in line with stream flow data recorded at the Kitsap Public Utilities Department's upstream monitoring gauge [figure 23]. High peak flows occurred in December 2014 and February 2015 at all monitoring sites. Lower flows predictably were recorded during summer months, although in the project data higher flows were measured in 2014. This is related to sampling at high tidal stages. Site 1 flows ranged from 1.7cfs in April 2015 to 39.5 in December 2014. Site 2 flows showed a similar range at 5.21cfs in August 2015 to 43.6cfs in February 2015. Site 3 flows ranged from 2.22cfs in September of 2015 to 40.7cfs in February 2015. Likewise Site 4 had flows ranging from 2.6cfs in July 2014 to 48.3cfs in February 2015. 


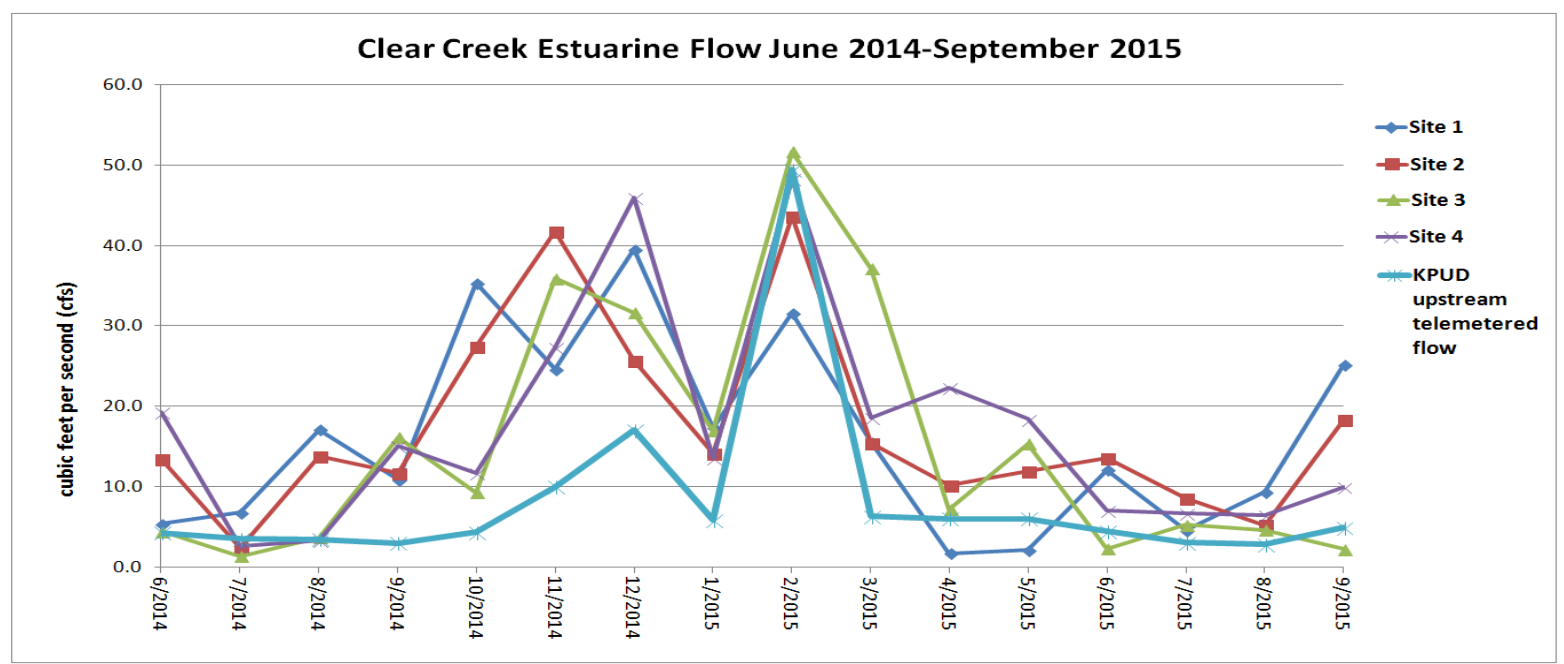

Figure 23: 2014-2015 measured flows in Clear Creek Estuary at Monitoring sites and Kitsap Public Utilities Department's (KPUD) telemetric gauge for the Clear Creek mainstem show a consistent pattern of low summer and high winter flows.

\section{Invertebrates}

In-stream and shoreline samples collected during July 2015 show low diversity. The most commonly captured species were amphipods (Corophium brevis) also known scuds or side swimmers at sites 1 and 2 [table 13]. Amphipods are a pollutant tolerant species and were found in both stream and shoreline sampling locations using water column grab sampling and pit traps, respectively. Black flies (family simuliidae) and water penny beetles (family psephenidae) were the next most commonly captured species. In addition to slight diversity, abundance values were also trivial. 
Table 13 Invertebrate sampling results, identified to family, illustrated a low abundance and diversity. The three species found most commonly were pollution tolerant species.

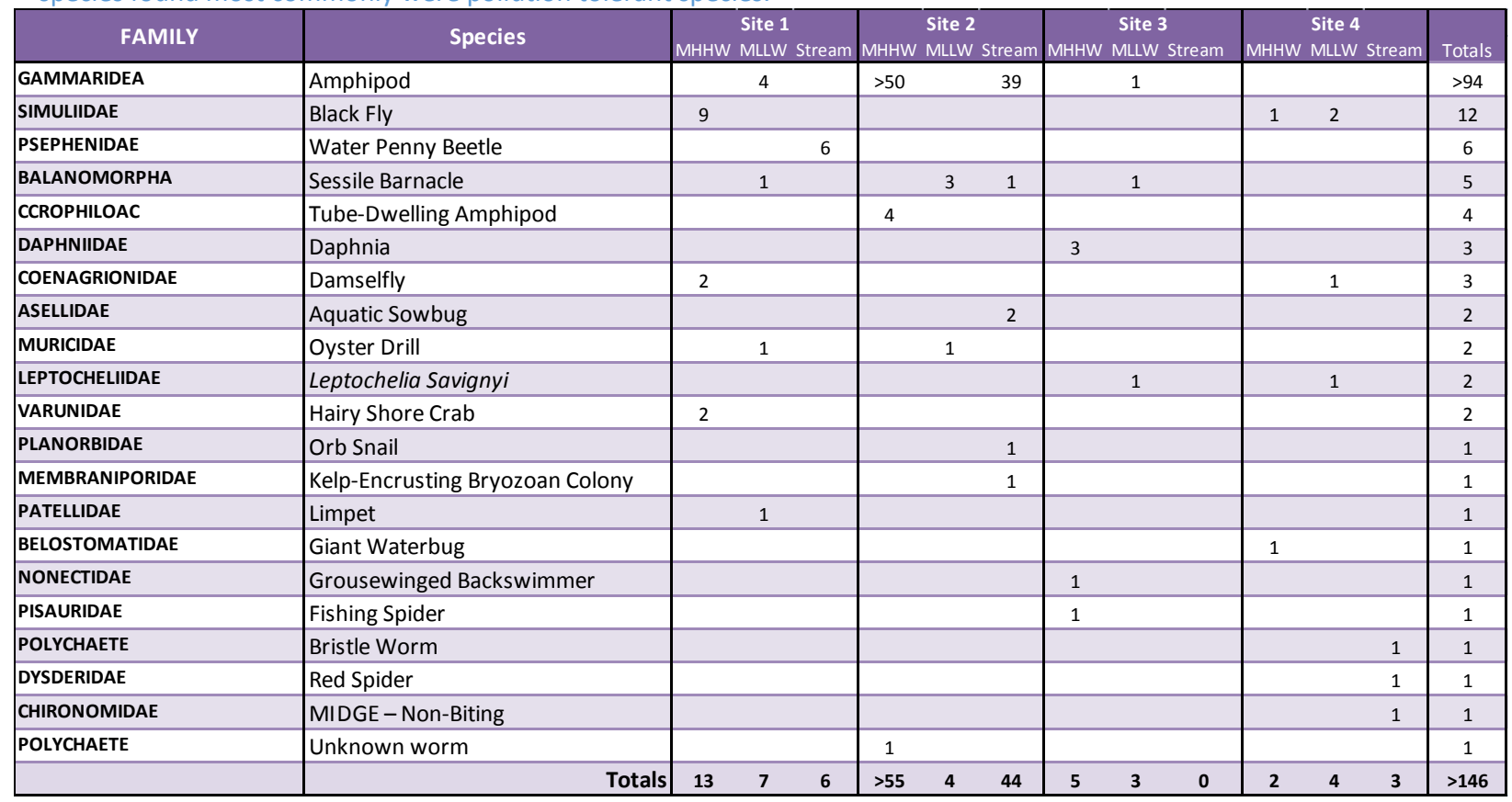

\section{Vegetation}

Observations of plant communities along the estuary shorelines show a diversity of native species at all locations and comparably low diversity and abundance of invasive plants [table 18]. Predominate species at the two most marine influenced sites was saltwort (Salicornia virginica). Saltwort comprised $70.5 \%$ of the plant community at site 1 and $43.8 \%$ at site 2 . Though not a dominate species at site 3 , large groupings were found there as well. The sampling sites located north of the culverts were dominated by Lyngbye' sedge (Carex lyngyei; $58.8 \%$ and $31.3 \%$ at sites 3 and 4, respectively). Large communities of non-native species were also found at each of the sites. English ivy (Hedera helix) and red goosefoot (Chenopodium rubrum) only were present as dominant species at Site 3 and 4, respectively [table 14]. The full listing of identified species is available in Appendix $\mathrm{E}$. 
Table 14: Vegetation survey results show that the top three dominate species, cumulatively in the eight quadrats per site, were found to be native plants such as saltwort and Lyngbye's sedge. The two sites located north of the bridge also had large groupings of non-native plants, including English ivy and red goosefoot. Invasive species are shown in red text.

\begin{tabular}{|l|r|}
\hline SITE 1 & TOTAL \\
\hline SALTWORT Perennial saltwort or pickleweed (Salicornia virginica) & $70.5 \%$ \\
\hline GUMWEED (Gridelia integrifolia) & $18.8 \%$ \\
\hline SILVER BURWEED (Ambrosia chamissonis) & $10.3 \%$ \\
\hline SITE 2 & TOTAL \\
\hline SALTWORT Perennial saltwort or pickleweed (Salicornia virginica) & $43.8 \%$ \\
\hline SILVERWEED (Potentilla anserine ssp. pacifica) & $14.3 \%$ \\
\hline GUMWEED (Gridelia integrifolia) & $12.5 \%$ \\
\hline SITE 3 & TOTAL \\
\hline LYNGBYE'S SEDGE (Carex lyngbyei ) & $58.8 \%$ \\
\hline ENGLISH IVY (Hedera helix) & $23.8 \%$ \\
\hline COMMON SNOWBERRY or WAXBERRY (Sympjoricarpos albus) & $11.3 \%$ \\
\hline SITE 4 & TOTAL \\
\hline GIYNGBYE'S SEDGE (Carex lyngbyei ) & $31.3 \%$ \\
\hline SALTMARSH GRASS (Distichlis spicata ) & $27.5 \%$ \\
\hline RED GOOSEFOOT or COW SPINACH (Chenopodium rubrum ) & $16.3 \%$ \\
\hline
\end{tabular}

\section{Sediment Size Composition}

Sediment composition was found to be largely a consequence of location. Predominance of materials was strongly related to whether the sampling transect lay on the south or north side of the Bucklin Hill Bridge [table 15].

\begin{tabular}{|c|c|c|c|c|c|}
\hline \multirow[b]{2}{*}{ Material } & \multicolumn{2}{|c|}{ Southern Transects } & \multicolumn{2}{|c|}{ Northern Transects } & \multirow{2}{*}{$\begin{array}{c}\text { Average } \\
\text { All }\end{array}$} \\
\hline & Site 1 & Site 2 & Site 3 & Site 4 & \\
\hline Cobble & $17.2 \%$ & $25.1 \%$ & $2.4 \%$ & $4.5 \%$ & $14.3 \%$ \\
\hline Pebble & $19.0 \%$ & $26.0 \%$ & $10.9 \%$ & $16.0 \%$ & $18.2 \%$ \\
\hline Granules & $15.0 \%$ & $24.6 \%$ & $7.7 \%$ & $9.0 \%$ & $14.5 \%$ \\
\hline Sand & $37.2 \%$ & $17.5 \%$ & $3.8 \%$ & $6.6 \%$ & $25.0 \%$ \\
\hline \multirow[t]{2}{*}{ Silt/fines } & $11.6 \%$ & $6.8 \%$ & $75.3 \%$ & $63.9 \%$ & $28.0 \%$ \\
\hline & $100.0 \%$ & $100.0 \%$ & $100.0 \%$ & $100.0 \%$ & $100.0 \%$ \\
\hline
\end{tabular}

Bankful width compositions downstream, to the south of the embankment, contained greater average percentages of sand (17.5-37.2\%), pebble (19.0-26.0\%), cobble (17.2$25.1 \%)$, and granules (15.0-24.6\%) than silt/fines (6.8-11.6\%). Conversely, upstream and north of the bridge sediment compositions were mostly silt/fines (63.9-75.3\%) and pebble (10.9-16.0\%) with relatively small amounts of granules (7.7-9.0\%), sand (3.8$6.6 \%)$ or cobble (2.4-4.5\%). This distinctive sorting can be attributed to the sediment transport barrier formed by the artificial berm, built in the mid-twentieth century, to support the bridge. This pattern is expected in the vicinity of dam like structures where 
smaller particles are deposited upstream of the obstruction and erosion on the downstream side exposes cobble and pebbles. Neither condition is conducive to creating salmonid habitat.

In-stream composition consisted of less silt (10.7\%) and more pebble (28.2\%) overall and by transect [table 16]. Pebble content was a higher percentage north of the bridge (37.5-45.0\% vs. 23.2-29.0\%). Southern wetted width transects contained more cobble (19.5-34.4\% vs. $10.0-15.0 \%)$, granules (23.0-30.5\% vs. $20.0-21.0 \%)$, and sand (13.3$22.2 \%$ vs. $12.0-13.5 \%)$ than those north of the bridge.

Table 16: Sediment Size by Site and Location for In-Stream/Wetted Segments of Transects composition contained mostly pebble sized substrate. South of the Bucklin Hill Bridge embankment, cobble predominated sediment size, while upstream pebble-sized substrate was more abundant.

\begin{tabular}{|l|r|r|r|r|r|}
\hline & \multicolumn{2}{|c|}{ Southern Wetted } & \multicolumn{2}{c|}{ Northern Wetted } & \multicolumn{1}{c|}{ Average } \\
\hline Material & \multicolumn{1}{|c|}{ Site 1 } & \multicolumn{1}{c|}{ Site 2 } & \multicolumn{1}{c|}{ Site 3 } & \multicolumn{1}{c|}{ Site 4 } & \multicolumn{1}{c|}{ All } \\
\hline Cobble & $19.5 \%$ & $\mathbf{3 4 . 4 \%}$ & $10.0 \%$ & $15.0 \%$ & $20.4 \%$ \\
\hline Pebble & $\mathbf{2 3 . 2 \%}$ & $29.0 \%$ & $\mathbf{3 7 . 5 \%}$ & $\mathbf{4 5 . 0 \%}$ & $28.2 \%$ \\
\hline Granules & $21.0 \%$ & $20.0 \%$ & $30.5 \%$ & $23.0 \%$ & $22.1 \%$ \\
\hline Sand & $22.2 \%$ & $13.3 \%$ & $12.0 \%$ & $13.5 \%$ & $18.6 \%$ \\
\hline Silt/fines & $14.1 \%$ & $3.3 \%$ & $10.0 \%$ & $3.5 \%$ & $10.7 \%$ \\
\hline & $100.0 \%$ & $100.0 \%$ & $100.0 \%$ & $100.0 \%$ & $100.0 \%$ \\
\hline
\end{tabular}

\section{Sediment Elevations}

Sediment elevation profiles at sites 1-4 were collected during the autumn of 2014 [figures 24-27, respectively]. The creek ran from north to south. On the north side of the bridge the stream flowed along the western bank until just before the bridge. It made a dramatic turn to flow due east along the bridge's base. On the south side of the embankment the stream initially ran along the eastern shore then began heading westerly again.

Site 1 , at $161.8 \mathrm{~m}$ was the widest and most southerly transit. Beginning on the eastern bank above $\mathrm{MHHW}$, the elevation decreased fairly rapidly over the first $20 \mathrm{~m}$. The angle of elevation change from then on was gradual until the thalwag. The thalwag lay in the center of the area between $57 \mathrm{~m}$ and $87 \mathrm{~m}$ from the eastern bank. This $30 \mathrm{~m}$ swath was nearly always wetted [figure 24]. A six meter wide sand and silt bar was situated between 66 and $72 \mathrm{~m}$. This was the northern tip of a much larger sediment deposition that split the creek flow into two channels as it left the estuary.

The $44 \mathrm{~m}$ width of Site 2 had the deepest profile, particularly under the most eastern outlet. This likely associated with culvert driven erosion. This site was located $42 \mathrm{~m}$ downstream of the culverts. The thalwag ran directly beneath the eastern culvert through a $3.5 \mathrm{~m}$ channel. Starting from the eastern bank and moving westward, the 
elevation decreased immediately to the thalwag. The area between $2.75 \mathrm{~m}$ and $9.25 \mathrm{~m}$ was nearly always wetted. The slope began to rise at a more gradual rate in the westerly direction then level off over the width of the old mill pond. The final $2 \mathrm{~m}$ showed a steep rise in elevation [figure 25].

Site 3 was $52 \mathrm{~m}$ wide and lay north of the culverts and existing berm which imposed a course change and eastward bend in the creek. At this site, load deposition created the most heavily silted sediments of all the sites. Aside from mounds of saltwort/glasswort found at $15 \mathrm{~m}$ and $21 \mathrm{~m}$ from the eastern bank, this profile exhibited low to moderate elevation changes. A meter deep drop occurred as the profile approached the thalwag area. Between $38.75 \mathrm{~m}$ and $42.1 \mathrm{~m}$ sediments were nearly always wetted. The western bank rose rapidly then leveled off [figure 26].

Site 4 at $10.4 \mathrm{~m}$ was furthest north from culverts and least often fully inundated with tidal waters. It was also the narrowest stream channel; therefore measurements were taken in 1 meter intervals. From the eastern bank the profile declines through a shallow slough then rises again across a flattened salt marsh plain. At the edge of the plain, the land drops steeply to a silty sand bank which was frequently wetted. The area between $8 \mathrm{~m}$ and $10.4 \mathrm{~m}$ was nearly always wetted [figure 27 ].

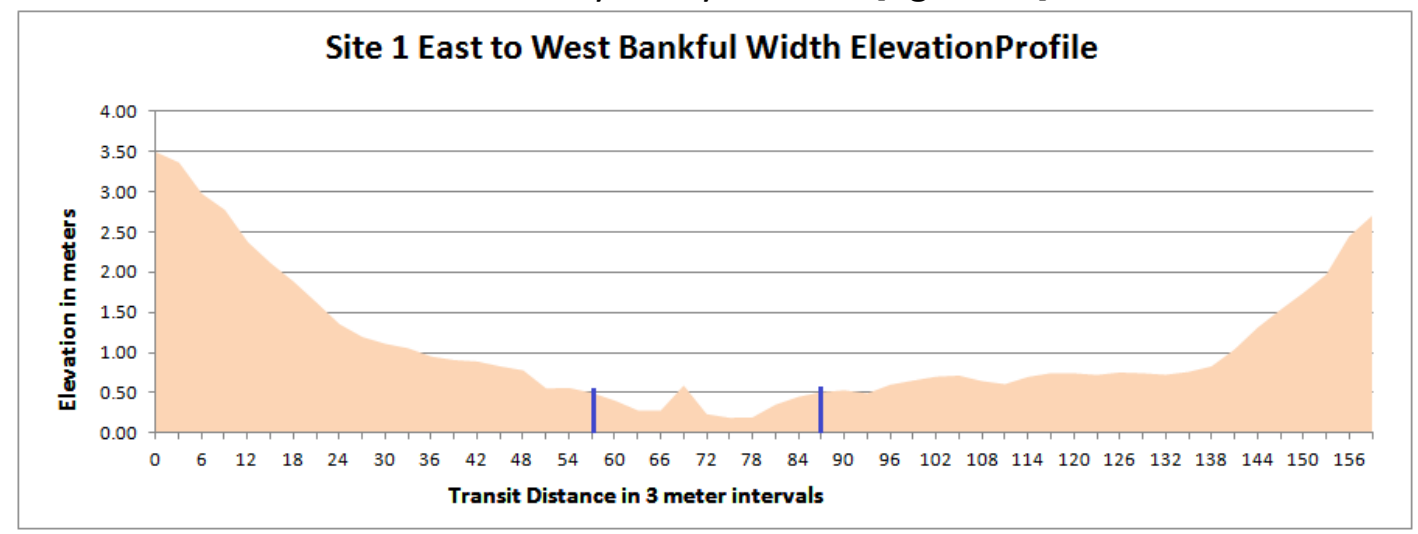

Figure 24: Site 1 at $161.8 \mathrm{~m}$ is the widest and most southerly transit. Starting from the eastern bank and moving westward, the elevation decreases rapidly then continues to sink at a more gradual rate. The area between $57 \mathrm{~m}$ and $87 \mathrm{~m}$ is nearly always wetted. A six meter wide sand and silt bar is situated between 66 and $72 \mathrm{~m}$. This was the northern tip of a much larger sediment deposition that split the creek egress into two channels. Approaching the last $30 \mathrm{~m}$ of the profile, the elevation again changed rapidly; however the gain was not a great as it reached $2.67 \mathrm{~m}$ high on the western bank versus $3.5 \mathrm{~m}$ high on the eastern side. 


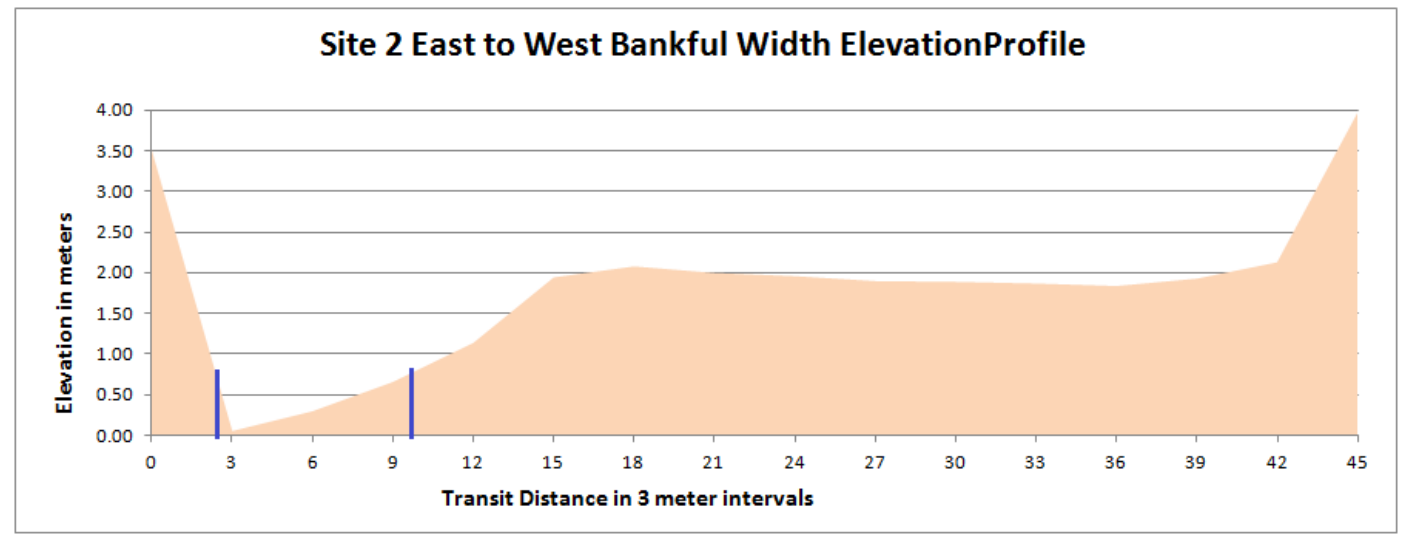

Figure 25: Site 2 is $44.02 \mathrm{~m}$ wide and most the deepest transit. This site lies $42 \mathrm{~m}$ downstream of the culverts. Starting from the eastern bank and moving westward, the elevation decreased immediately to the thalwag. The area between $2.75 \mathrm{~m}$ and $9.25 \mathrm{mwas}$ nearly always wetted. The slope began to rise at a more gradual rate in the westerly direction then leveled off over the width of the old mill pond. The final $2 \mathrm{~m}$ showed a steep rise in elevation.

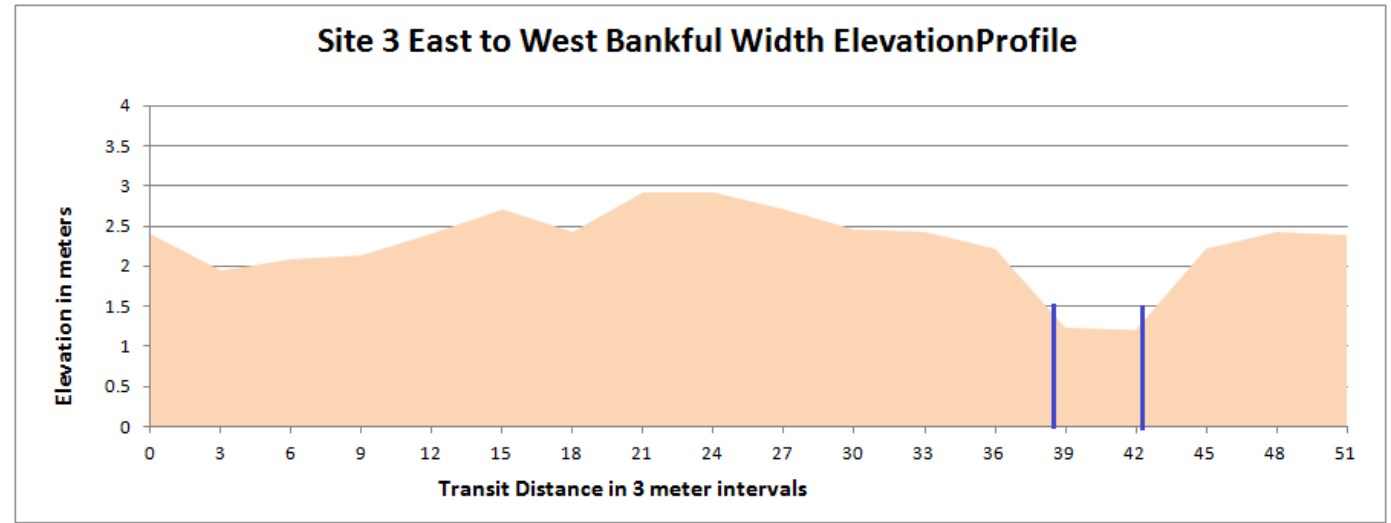

Figure 26: Site 3 at $52.10 \mathrm{~m}$ is the north of the culverts and existing berm which imposed an eastward bend in the creek. At this location, load deposition created the most heavily silted sediments of all the sites. Aside from mounds of saltwort/glasswort found at $15 \mathrm{~m}$ and $21 \mathrm{~m}$ from the eastern bank this profile exhibited low to moderate elevation changes. A meter drop occurred in the thalwag area, between $38.75 \mathrm{~m}$ and $42.1 \mathrm{~m}$, where it is nearly always wetted. The western bank rises rapidly then levels off.

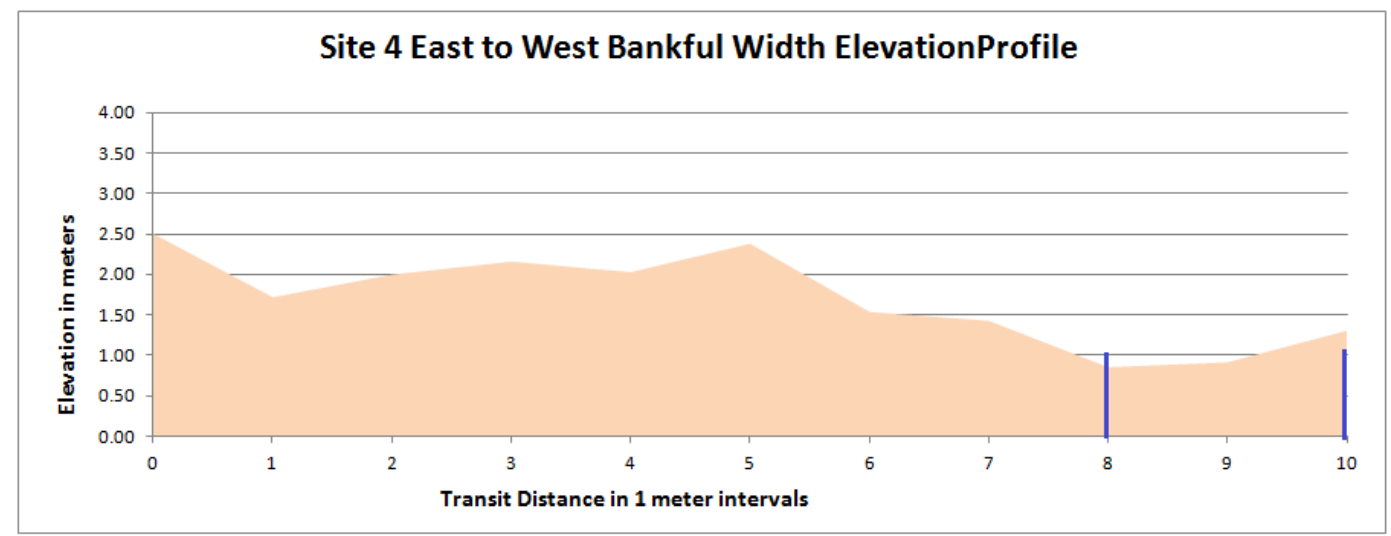

Figure 27: Site 4 at $10.4 \mathrm{~m}$ is the transit furthest north from culverts and least often fully inundated with tidal waters It is also the narrowest transit; therefore measurements were taken in 1 meter intervals. From the eastern bank the profile declines through a -shallow slough then rises again across a flattened salt marsh plain. At the edge of the plain, the land drops steeply to a silty sand bank which was frequently wetted. The area between $8 \mathrm{~m}$ and $10.4 \mathrm{~m}$ is nearly always wetted. 


\section{Beach Seines}

The variety of nearshore inhabitants recorded during the four 2014 seining events provided a snapshot of species utilizing the nearshore waters with $1 / 4$ mile $(0.4 \mathrm{~km})$ of the estuary. Data related to the types and number of forage fish helped to distinguish between residents and migratory species based on the repeated captured regardless of time of year [table 17]. Shiner perch (Cymatogaster aggregata) made up $47.25 \%$ of the summer's catch and were by far the most abundant species overall and in three of the four seine events. Staghorn sculpin (Leptocottus armatus) were second most abundant at $20.1 \%$ of the total collection and were present in all samples. Surf smelt (Hypomesus pretiosus), known prey of adult salmon, comprised the third largest grouping at $13.74 \%$. Unlike the more abundant species, smelt are transitory and were only captured during the first two seine dates. Unexpected finds were the American Shad (Alosa sapidissima) in the first June seine and Bay Goby (Lepidogobius lepidus) in the September beach seine. Both of the salmon species: Chum (Oncorhynchus keta) and Coho (Oncorhynchus kisutch) were juvenile stage fish.

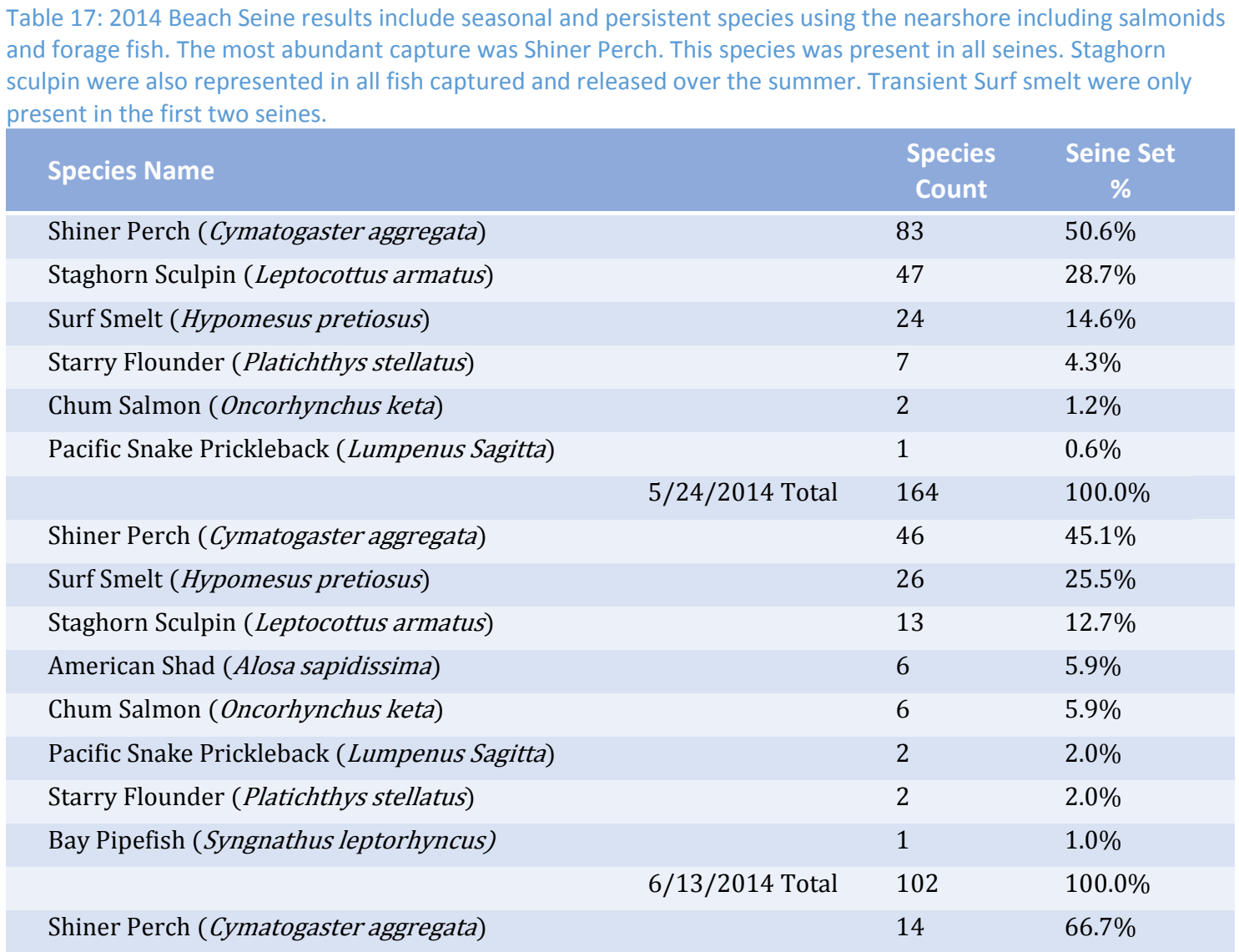




\begin{tabular}{|c|c|c|c|c|}
\hline Species Name & & $\begin{array}{c}\text { Species } \\
\text { Count }\end{array}$ & $\begin{array}{c}\text { Seine Set } \\
\%\end{array}$ & \\
\hline Staghorn Sculpin (Leptocottus armatus) & & 3 & $14.3 \%$ & \\
\hline Pacific Herring (Clupea pallasii) & & 2 & $9.5 \%$ & $0.5 \%$ \\
\hline \multirow[t]{2}{*}{ Starry Flounder (Platichthys stellatus) } & & 2 & $9.5 \%$ & \\
\hline & 6/20/2014 Total & 21 & $100.0 \%$ & \\
\hline Bay Goby (Lepidogobius lepidus) & & 36 & $46.8 \%$ & $9.9 \%$ \\
\hline Shiner Perch (Cymatogaster aggregata) & & 29 & $37.7 \%$ & \\
\hline Staghorn Sculpin (Leptocottus armatus) & & 10 & $13.0 \%$ & \\
\hline Coho Salmon (Oncorhynchus kisutch) & & 1 & $1.3 \%$ & $0.3 \%$ \\
\hline \multirow[t]{3}{*}{ Threespine Stickleback (Gasterosteus aculeatus) } & & 1 & $1.3 \%$ & $0.3 \%$ \\
\hline & 9/20/2014 Total & 77 & $100.0 \%$ & \\
\hline & Grand Total & 364 & & $100.0 \%$ \\
\hline
\end{tabular}

\section{Discussion}

Citizen Scientists - Restoration projects should include planning, implementation, and monitoring of the outcomes. Ideally, projects would include each of these factors. However, it is common that due to budget constraints monitoring is limited or eliminated. Coordination between experts, funders, and residents can help to mitigate budgetary gaps. A particularly effective approach to reducing the continuing costs of monitoring is by pursuing greater citizen involvement, such as making use of citizen scientists who have been taught how to collect the data of interest.

Research has shown that with appropriate training residents can aid ongoing environmentally focused studies. For instance, in a recent study, citizen scientists with limited training successfully identified plant species and their phenological stages (Fuccillo et al., 2015). The 2001 Fore et al. study showed that with training and appropriate tools, volunteers can identify benthic macroinvertebrates correctly to the family level nearly as well as professional scientists. It is on this basis that a measure of confidence in can be placed in the recruited citizens' ability to conduct scientific research.

Chemical and physical data related to salmon habitat suitability were collected in this project. This baseline data collection program helped to clarify how procedures should be communicated to volunteers. Concise verbal presentation of procedures, with physical props and well-segmented datasheets greatly improved the data recording process over the 17 months. While most collection efforts adhered to protocols, in some instances re-sampling/repeated analysis was necessary to ensure quality control, especially earlier in the monitoring program's history. Datasheets for each segment of habitat monitoring: water quality, elevations, invertebrate, and vegetation surveys went through several iterations to create a user friendly form. The simplified and 
annotated formats were found to improve participants understanding of the goals and facilitate quality data collection. In addition, less follow up was needed to assure the quality of the information being collected and recorded while in the field and in the lab.

Water Quality - The physical and chemical quality of water has an impact on the quality of life the aqueous body can sustain. Multi-parameter digital probes can precisely and accurately capture low, non-lethal dose aqueous concentrations. However in this study, the ability to measure low level concentrations of chemical components was restrained. Due to budget limitations manual methods of water analysis were more commonly used. Human errors and detection limits lead to results that are more suited to comparison of results over time rather than establishing concentrations. This monitoring program was designed and adapted to capture and evaluate the trends in chemical and physical attributes of the estuary. This discussion focuses on four parameters that are particularly important components of suitable salmon habitat.

1. Salinity - Diurnal tidal activity modifies the concentration of salts, chlorine (Cl-), sulfates $\left(\mathrm{SO}_{4}\right)$ and bicarbonate $\left(\mathrm{HCO}_{3}\right)$ found in the alternately fresh and brackish waters and therefore the density of estuarine waters. Large differences in the salinity values were noted although none outside of expected values when they are related to low tide or high tide sampling times. Salinity values do however compel which water quality standards are applicable. The baseline data indicate application of marine water use standards for Sites 1-3 and freshwater use standards for Site 4. Site 4 is subject to the freshwater use standards as $95 \%$ of the salinity measures were equal to $1 \mathrm{ppt}$ or less.

2. $p H$ - The $\mathrm{pH}$ level affects the solubility (amount that can be dissolved in the water) and biological availability (amount that can be utilized by aquatic life) of chemical constituents such as nutrients (ex: phosphates and nitrogen compounds) and heavy metals (ex: copper and zinc). Lower $\mathrm{pH}$ values make metals more available for uptake. Results in the baseline studies found both the marine and freshwater to be generally in the neutral to slightly basic range with an average of 8.43 and standard deviation of 0.50 . In June and July of 2015 readings over 9.0 were recorded at all of the monitoring sites. In addition to the probe readings, phenolphthalein alkalinity concentrations ranging from 4.0 to $100 \mathrm{ppm}$ were calculated. Data points for this parameter were not present during any other sampling dates and indicate the presence of carbonates or hydroxide ions. Basic $\mathrm{pH}$ readings (above 8.5) create issues for aquatic life. For instance, a high $\mathrm{pH}$ can result in greater toxicity of nonionized ammonia [ $\mathrm{NH}_{3}$ in concentrations greater than $5 \mathrm{mg} / \mathrm{L}$ ]. Sources of higher $\mathrm{pH}$ levels can include mid-day peaks in aquatic plant photosynthesis and excess nutrients (USGS, 2016). Both contributing conditions were present. Samples were collected mid-day near or within large groupings of sea lettuce green algae (Ulva 
lactuca) in sites 1-3. In addition, during the July 2015 sampling, phosphate $\left(\mathrm{PO}_{4}{ }^{3-}\right)$ concentrations were found to be greater or equal to $5 \mathrm{mg} / \mathrm{L}$.

3. Dissolved oxygen ( $D O)$ - Rapidly moving, cooler water, which is a common condition in late fall through spring, contained a high concentration of dissolved oxygen (DO). Calm and warmer water, such as often occurs in summer and early fall, contained less. Data collected during summer months of the baseline study indicate higher levels of phosphates and total ammonia. In addition, biological oxygen demand resulting from decomposition of organic matter during warmer months may reduce dissolved oxygen concentration. Clear Creek is 303(d) listed by the Washington DOE for failure to comply with the State's Water Quality Standards for DO. Summer month samples held insufficient DO levels at Site 4 to meet salmonid habitat needs. Levels should not decrease below $9.5 \mathrm{mg} / \mathrm{L}$; however the average reading was $7.3 \mathrm{mg} / \mathrm{L}$ indicating that salmonids would need to seek refuge in another location in order to survive.

4. Temperature - Water temperature affects the concentration and activity of ions in water, particularly the reactivity of chemicals and metals. In the Puget Sound low land streams, such as Clear Creek, most aquatic life (fish and insect larvae) is adapted to life in cooler waters. Cooler waters hold greater quantities of dissolved oxygen. "Temperature can affect embryonic development; juvenile growth; adult migration; competition with non-native species; and the relative risk and severity of disease." (WA DOE). The baseline study found excursions below fair quality marine temperatures at Site 1 during August of both 2014 and 2015. This condition could be a deterrent to outward migration of juvenile salmonids. Upstream temperatures were cooler and in line with state standards except at the far end of the estuary (Site 4) where freshwater uses standards apply. Higher temperatures reduce dissolved oxygen content in water. Exceedances of the temperature maximum for summer habitat could be problematic for parr if they do not have access to pools or otherwise cooler waters.

Flow: Flow can serve as an indicator of exchange rates of nutrients and sediment movement rates. High flow rates can destabilize stream banks and trigger erosion. Prior to development in the area it appears stream flow ranges were lower. Prior to the land berm based bridge and urban development in the Clear Creek watershed, "Stream discharge records were kept on only one year, from July to October 1947 and show a range in flow from 1.5 to 9.0 cfs" (DFW, 1971). Precipitation records indicate average precipitation occurred in 1947. Four decades later peak flows for the creek were reported as high as $235 \mathrm{cfs}$ after development (KPUD, 1997). Current readings are closer to the average peak recorded prior to the berm installation at Site 4 (8.8cfs in summer). Stormwater management practices such as bio-swales could be contributing 
to restrained flow in spite of continued increases in impervious area surrounding the creek and estuary. Moderate stream flows are important for salmonids in terms of facilitating oxygen exchange with the atmosphere without causing erosive bank scouring. This project recorded flows peak flows nearing $50 \mathrm{cfs}$ at each of the sites during higher tides or heavy precipitation which could lead to redd scour. On the other end of the spectrum, low flows, for instance in the summer months of 2015 when water depths of less than a third of a meter were recorded, could also be challenging to salmonids due to lack of thermal refuge.

Invertebrates and other nearshore inhabitants Invertebrates are a valuable food source for juvenile salmon. Determining whether there is an adequate food supply for juvenile salmon using the estuary as a rearing space provides evidence of habitat suitability. Cataloging to date indicates low diversity and that the majority of arthropod species are pollution tolerant. These findings are similar to macroinvertebrate monitoring conducted by Clean Water Kitsap which indicates ranges from "good" in upstream reaches to "poor" closer to the estuary. (KCPW, 2006) Procedures will however need additional refinement. Invertebrate collection exercises were successful; however several of the in-stream samples from Site 4 were damaged during preparation for microscopic identification. Continued sampling of pelagic and benthic invertebrates can aid in the determination as to whether there is a food supply for juvenile salmon using the estuary as a rearing space. Invertebrates are acknowledged as good indicators of stream health; however standards or even guidance related to estuarine invertebrates as habitat indicators is sparse to nonexistent (EPA, 2007). The State of Washington has established a biological scoring system for freshwater habitat through use of the Benthic Index of Biotic Integrity (B-IBI), but has not developed a similar guide for brackish waters. This baseline study could perhaps aid in creating/supplementing a knowledge base of estuarine invertebrates for the Dyes Inlet area.

Sediments: Sediment composition affects the types of invertebrates as well as spawning forage fish and salmonids using the area. The quantities of silt in the Clear Creek thalwag create poor quality habitat for spawning salmon and juvenile salmon prey. As the sediment that has been deposited on north side of the Bucklin Hill Bridge embankment begins to move through stream and tidal action, more in-stream cobble should begin to be exposed thus creating better macroinvertebrate habitat. Since Clear Creek is a low elevation stream most sediment removal will be tidally driven. The baseline data will be most useful for comparison purposes to post-construction profiles. It will be of interest to document whether the creek continues to follow the berm and culvert induced curved path toward the east before entering Dyes Inlet or begin to straighten its course back towards alignment noted in the 1881 "T-sheet" aka shoreline survey mapping. 
Seining: Documenting the presences and abundance of forage fish species as well as juvenile salmonids can lend support to determining whether or not nearshore waters provide the type of prey that are necessary for salmonid survival. Species data from 2014 indicate forage fish and salmonids utilize the nearshore of northern Dyes Inlet. Data from 2015 were not available at the time of this report preparation; therefore a year-to-year comparison of the species was not completed. Receipt of those data along with post-construction data may provide a basis for comparison of any changes in fish assemblages near the estuary.

Vegetation: Both aquatic and terrestrial plants provide critical components related to suitable salmon habitat. Our project identified mostly native vegetation directly next to the shoreline. Aquatic vegetation supports habitat or nutrients for invertebrates that can in turn provide a food source for juvenile salmon. Terrestrial vegetation can provide a temperature refuge for juveniles rearing in the stream and estuary through shading of the stream. Shading also provides camouflage for migrating fish. Stream shading occurred mostly at Site 4 where trees and larger shrubs grew close to flowing waters. Downed vegetation such trees and large woody shrubs can also aid salmon though formation of deeper pools and protective barriers to diving predators. Increased flushing from reopening of the estuary to Dyes Inlet may result in less retention of recruited woody debris. Vegetative shading and refuge may also be reduced, particularly if bank erosion increases.

\section{Conclusion}

\section{The Need for Monitoring}

The majority of the world's populations live in urbanized settings, placing burdens of expansion on metropolitan streams and their estuaries. By using protection legislation such riparian buffers and low impact development requirements, city and regional planners are making great strides in retaining the ecosystem services of urban water bodies in areas undergoing growth. However, myriad pre-existing conditions have degraded their physical and biogeochemical integrity. Many disconnected terrestrial and aquatic ecological interactions can only be corrected through reestablishment of their natural functions.

According to the Environmental Protection Agency, among the many advantages to urban stream repair for communities are reduced flooding, riparian soil filtration of nutrients and toxins, recharge of groundwater - the source of most community drinking water and improved habitat that supports healthy wildlife populations. In addition, streams flow into estuaries and healthier conditions in urban streams lead to 
healthier estuarine conditions. For estuaries which serve as migration corridors and rearing habitat for anadromous fish is it critically important to establish the connection between healthy streams, healthy estuaries, and healthy salmon populations.

Studies indicate that monitoring is the most commonly underutilized restoration practice (Collins, et al., 2007). Documenting original conditions and then where and what changes are occurring provides a method for recording the successful aspects of the restoration and an opportunity to create a positive feedback loop for restoration efforts.

\section{The Need for Citizen Scientists}

Although one can expect certain biogeochemical factors to play a part in the outcome, each site has unique geographical features. The unique details of a site along with the level of disturbance it has or will undergo during restoration calls for the need to collect data before and after reconstruction projects are completed in order to assess its success. This work is often time consuming, In addition, monitoring should be carried out for an extended period of time, thereby making it expensive. The associated costs can be minimized by utilizing trained volunteers aka citizen scientists in the monitoring process.

Citizen scientists are unpaid volunteers, who collect and/or analyze data in support of scientific research related to the outcomes of modifications (Dickinson, et al., 2010). There are varieties of science-based assignments that citizen scientists can successfully complete (Silvertown, 2009) and they can contribute valuable data that may otherwise be unavailable to future researchers. It is a logical evolution in restoration project management to include interested residents. By training volunteers in basic estuarine water quality monitoring methods the citizen scientists will be provided with information on estuary management and restoration practices. Citizen monitoring programs increase scientific literacy for volunteers and other community members (Middleton, 2001). The hands-on involvement provides opportunities for volunteers to interact with nature. This results a greater sense of well-being in their physical and mental health (Thoits et al., 2001). Observations by citizens and data from scientists have elicited increased concern for maintaining or improving the health and functionality of urban streams. The commitment to long-term gathering of quality data can prompt participants to share their knowledge and experience. Such sharing can inform local land use decisions, which can have a direct effect on biodiversity (Cooper et al., 2007). Educating residents in the watershed regarding water quality and habitat interactions is targeted to encourage pollution prevention, environmental stewardship, 
and support for aquatic restoration projects.

\section{Expected Results of the Restoration}

The collection of baseline water quality data during this phase of the Clear Creek Trail Alliance habitat monitoring program, plus information on other aquatic and terrestrial indicators will provide a basis for measuring whether modification to the Clear Creek Estuary from the Bucklin Hill Bridge Project has resulted in improved habitat for native salmon. Several indicators supporting an assessment of improved habitat may be revealed from the data collected over time.

The reconstruction of the Bucklin Hill Bridge should allow a more natural hydrological connection between Dyes Inlet and Clear Creek. Well-flushed estuaries are intrinsically more robust and should result in the following in water quality:

Streamflow is unlikely to change significantly, however with the removal of the culverts and embankment an increase in rate may be noted at Sites 1-3. Marine hydrology will be restored allowing unrestricted sediment and nutrient exchange between the freshwater of the creek and the nearby marine waters. Fines deposited upstream of the bridge over the past 70 years will begin to move outward into Dyes Inlet and expose cobble and pebble in the upper streambeds. This will improve habitat for some benthic invertebrates and perhaps contribute to a slight increase in flow.

Salinity is likely to increase at the upstream sites ( 3 and 4 ) as the unrestricted tidal waters are able to move further into the estuarine area. Salinity proliferation can decrease oxygen solubility thereby periodically negatively impacting dissolved oxygen concentrations. Salt intolerant upstream vegetation located above the former tidal limit, but below the new inundation extent will die off. As this area transitions to salt marsh vegetation will eventually be replaced by halophytes (species that have adaptations for dealing with saltwater effects). In the interim this could lead to intensified erosion of the upstream banks.

Dissolved Oxygen should increase as streamflow churns over riffles in the streambed created as embedded gravel is cleaned of silt. Tidal waters may also transport plankton and algae into the estuary. These plants could increase DO production via respiration. However if they aren't consumed or flushed outward upon death they could also reduce DO concentrations through the greater biological oxygen demands of decay. In addition, the greater coverage of the estuary by saline tidal waters could temporarily and diurnally reduce DO concentrations. 
Temperature in the stream should decrease along with wash out of fine silt sediments by high tides. Also, in the baseline study, incoming marine water temperatures are slightly cooler than the stream outflow $\left(15^{\circ} \mathrm{C}\right.$ vs. $15.7^{\circ} \mathrm{C}$ on average). Bank destabilization from those marine waters on the other hand may confound that affect by causing more sediment to enter the stream. However bank erosion could also lead to natural recruitment of large woody debris (LWD) in the stream and could produce pools of deeper cooler water, particularly at the more northern reaches.

If habitat for salmon improves as a result of the bridge replacement project monitoring workers would expect to see annual runs of Chinook, Chum, and Coho salmon as well as Steelhead increase dramatically over time. Supporting a reasonable hope for increased utilization of the creek by spawning salmon is the annual springtime release of nearly 1,000 Chum and/or Coho salmon fry associated with the culmination of Salmon in the Classroom programs. The improved habitat should increase preferred prey abundance due to greater nutrient and sediment exchange thus improving parr survival rates in the estuary. This sets the stage for survivors to return to Clear Creek after maturation in the oceanic environment. The presence of large cohorts in other nearby local streams also creates a possibility of opportunistic use of Clear Creek for spawning by non-natal salmon. For instance, Chico and Barker Creeks host such numbers as to warrant viewing events such as the Salmon Viewing and Tours Days.

\section{Recommendations}

The CCTA should continue to adapt datasheets and training guides to suit the needs of their participants, but also be certain to retain the key components of the procedures to ensure quality in collected information is not compromised.

The CCTA may wish to consider streamlining their monthly monitoring criteria. Not all parameters related to water quality have a comparable Washington State water quality standard. These data would not be reportable to the State's Water Quality Monitoring Program. CCTA may determine that the program will be focused on reportable parameters such as DO, pH, temperature as well as salinity. Though not reportable, salinity levels are a driver in the selection of the particular Beneficial Use Standards that are applicable to each site. For some of the parameters, such as nitrates, nitrites, methyl orange acidity, and metals, the data sets had undetectable values. Data that are not reportable or provide no trend could be excluded. Conversely, the CCTA may wish to continue collecting all data parameters throughout the construction period and for the year following the reopening of Bucklin Hill Road. This will allow them to confirm that breaching of the berm and reopening of the road continues to result in no metals 
or excess nutrients in the water column. I would recommend in particular that metal testing be continued as measurement of the successfulness of the bio-filtration devices being installed as stormwater and road runoff treatment. The presence of dissolved heavy metals such as copper or zinc, formerly adsorbing to sediment in the water column due to incomplete bioremediation, may reduce the quality of the estuary as habitat. Dissolved metals may interfere with predator avoidance in juvenile salmon or navigation in adult salmon returning to spawn.

Regardless of whether the number of parameters collected is reduced or not, the CCTA should plan to continue data collection for a minimum of three years following the reopening of the estuary in order to gauge whether habitat is improving for salmonids. They should continue to engage citizens of all ages and particularly students of local collegiate level environmental programs to provide an opportunity to learn and apply habitat monitoring techniques.

\section{Acknowledgements}

It is with great thanks that I acknowledge the support and assistance of Mary Earl of the Clear Creek Alliance for giving me the opportunity to design and implement this program as well as Drs. Joseph Maser and Eugene Foster of Portland State University for their instruction and advice throughout the project. I would also like to thank: Jolene Palmer of Stillwaters Environmental Center for providing guidance in developing quality assurance and control protocols and documentation; Jeff Adams of SeaGrant for instruction and the equipment needed to complete elevation profiles; Elizabeth Grady for sharing her Beach Naturalist and native plant knowledge; Western Washington Huxley College of the Environment on the Peninsulas' environmental science professor, Jenise Baughman for her classes participation and for her assistance in arranging an internship, John Adamson for serving as an intern on this project; Kitsap County Health Department for aiding in data collection and providing historical fecal coliform data for Clear Creek and Dyes Inlet; Clean Water Kitsap for loans of waders, kick nets, and other equipment that helped volunteers to complete sampling; and of course the many volunteers who contributed time and effort to collect and analyze the habitat data. 


\section{References}

Aspect Consulting. 2013. Geotechnical Report. http://www.bucklinhill.com/pdf/Bucklin\%20Hill\%20Road\%20Geotechnical\%20R eport\%20-\%20Final.pdf

Bednarek, Angela. 2001."Undamming Rivers: A Review of the Ecological Impacts of Dam Removal." Environmental Management 27(6):803-814.

Berger/Abam engineers, Inc. 1998. Bucklin Hill Roadway Improvements: Blaine Avenue NW to Tracyton blvd. NW Final Design Report Volume 1 of 2 - Text and Appendixes.

http://www.kitsapgov.com/pw/pdf/CRP 3644/CRP 36441998 preliminary re port.pdf

Berger/Abam engineers, Inc. 1998. Bucklin Hill Road Widening Project Final Environmental Impact Statement (FEIS). http://www.kitsapgov.com/pw/pdf/CRP 3644/CRP 3644 Bucklin HillFinal\%20EIS.pdf

Booth, D. B. and Goldstein, B. 1994. "Patterns and Processes of Landscape Development by the Puget Lobe Ice Sheet," in Regional Geology of Washington State. Olympia: Washington State Department of Natural Resources Division.

Brinker, R. C., \& Minnick, R. 1995. The surveying handbook. Dordrecht: Springer Science+Business Media, B.V

Burroughs, B.A., Hayes, D.B., Klomp, K.D., Hansen, J.F., Mistak, J. 2009. Effects of Stronach Dam removal on fluvial geomorphology in the Pine River, Michigan, United States. Geomorphology Vol. 110. 96-107.

Carter, K. 2005. The Effects of Temperature on Steelhead Trout, Coho Salmon, and Chinook Salmon Biology and Function by Life Stage California Regional Water Quality Control Board: Implications for Klamath Basin TMDLs. http://www.swrcb.ca.gov/northcoast/water issues/programs/tmdls/shasta riv er/060707/28appendixaetheeffectsoftemperatureonsteelheadtroutcohosalmon andchinooksalmonbiologyandfunction.pdf

Clear Creek Trail. 2016. Clear Creek Trail Alliance. http://www.clearcreektrail.org/members.htm

Clear Creek Trail. 2016. Salmon in the Classroom Program. http://www.clearcreektrail.org/Auction.htm

Collins, M. Lucey, K., Lambert, B., Jon Kachmar, J., James Turek, J., Hutchins, E., Tim Purinton, T., and Neils, D. 2007. Stream Barrier Removal Monitoring Guide. Gulf of Maine Council on the Marine Environment. www.gulfofmaine.org Lstreambarrierremoval. 
Cooper, C. B., Dickinson, J., Phillips, T., \& Bonney, R. 2007. Citizen science as a tool for conservation in residential ecosystems. Ecology and Society 12(2): 11

Cultural Resources Consultants, Inc. 2013. Cultural Resources Assessment. http://www.bucklinhill.com/pdf/Cultural\%20Resources\%20Assessment\%20\%201207A-2\%20Bucklin\%20Hill\%20Rd\%20Phase\%202\%20Tech\%20Memo.pdf

Dawson, M.N., Raskoff, K.A., and Jacobs. D.K. 1998. Field preservation of marine invertebrate tissue for DNA analyses. Molecular Marine Biology and Biotechnology (1998) 7(2), 145-152. http://mnd.ucmerced.edu/assets/PDFs/1998Dawson\&c.pdf

Delzer, G.C, and McKenzie, S.W. 2003. Five-day Biochemical Oxygen Demand. U.S. Geological Survey, National Field Manual for the Collection of Water-Quality Data (TWRI Book 9), Chapter A7. Biological Indicators. http://water.usgs.gov/owq/FieldManual/Chapter7/NFMChap7 2 BOD.pdf

Dickhoff, W.W., Beckman, B.R., Larsen, D.A., Duan, C., and Moriyama S. 1997. The role of growth in endocrine regulation of salmon smoltification. Fish Physiology and Biochemistry 17: 231-236, 1997. 231 (C) 1997 Kluwer Academic Publishers. Printed in the Netherlands.

Dickinson, J.L., Zuckerberg, B., and Bonter, D.N. 2010. Citizen Science as an Ecological Research Tool: Challenges and Benefits. Annual Review of Ecology, Evolution, and Systematics Vol. 41: 149-172

Diersing, N. 2009. Water Quality: Frequently Asked Questions. Florida Keys National Marine Sanctuary. http://floridakeys.noaa.gov/scisummaries/wqfaq.pdf

Dingman, S.L. 2002. Physical Hydrology $\left(2^{\text {nd }}\right.$ ed). Long Grove, IL. Waveland Press, Inc.

du Bray, E.A. 1995. OFR-95-831: Preliminary Compilation of Descriptive Geoenvironmental Mineral Deposit Models. U.S. Geological Survey. ii, 272 p. :ill.; $28 \mathrm{~cm}$.

Dyes Inlet/Clear Creek Watershed Management Committee, Kitsap County Department of Community Development, Economic and Engineering Services, Inc., and Shapiro and Associates. 1992. Dyes Inlet/Clear Creek Watershed Action Plan.

Economic and Engineering Services, Inc., Shapiro and Associates, and Washington Department of Ecology. 1991. Technical Appendix A of Dyes Inlet/Clear Creek Watershed Action Plan. Table I-2 p. I-94.

Edwards, P. 2008. Stream Insects of the Pacific Northwest. Center for Science Education.

Fohn, Mindy. 2009. Bacterial Pollution Reduction in an Urban Watershed. Kitsap County Public Works, Surface and Stormwater Management. 
Fore, L. S., Paulsen, K., and O'Laughlin, K. 2001. Assessing the performance of volunteers in monitoring streams. Freshwater Biology. Vol. 46: 109-123.

Fuccillo, K. K., Crimmins, T.M., de Rivera, C.E., Elder, T.S. 2015. Assessing accuracy in citizen science-based plant phenology monitoring. International Journal of Biometeorology. Vol. 59,Issue 7, pp 917-926.

Kitsap County Department of Community Development. 1987. Draft Environmental Impact Statement for the Clear Creek Master Plan.

Kitsap County Public Works. 2006. Dyes and Sinclair Inlet Creeks Benthic Macroinvertebrate Biological Monitoring Results 1998 - 2006. http://www.kitsapgov.com/sswm/pdf/graph dyes sinclair creeks.pdf

Kitsap County Public Works. 2013. Bucklin Hill Bridge Project Reports: Raising the Roadway of the Estuary by 5 feet. http://www.kitsapgov.com/pw/pdf/RAISING\%20THE\%20ROADWAY\%20FIVE\%2 OFEET\%20-\%20handout.pdf

Kitsap County Public Works. 2014. Clear Creek Floodplain Restoration. http://www.kitsapgov.com/sswm/Clear Creek Floodplain Restoration.htm

Kitsap County Public Works. 2014. Clean Water Kitsap Restoration Projects. http://www.cleanwaterkitsap.org/Pages/Restoration-Projects.aspx

Kitsap County Public Works. 2015. Bucklin Hill Bridge Project. http://www.bucklinhill.com/bucklinhill project.htm

Kitsap County Public Works. 2016. Salmon in the Classroom. http://www.kitsapgov.com/sswm/salmon.htm

Kitsap County Historical Society. 2014. "Silverdale." Charleston, South Carolina : Arcadia Publishing.

Kitsap Public Health District. 2013. Septic Systems. http://www.kitsappublichealth.org/environment/septic systems.php

Kitsap Public Utility District (KPUD). 1997. Kitsap County Initial Basin Assessment. http://www.kpud.org/downloads/kitsumm.pdf

Kitsap Public Utility District (KPUD). 2016. Kpud Daily Discharge Data: CC-Clear CreekMainstem Stream Gage. http://64.146.148.103/APSFED DISCHARGE.aspx

Kruckeberg, A. R. 1991. The Natural History of Puget Sound. Seattle: University of Washington Press. 1-33.

Lenntech Water Treatment Solutions. 2014. Zinc and water: reaction mechanisms, environmental impact and health effects. http://www.lenntech.com/periodic/water/zinc/zinc-and-water.htm 
Lindenmayer, D.B. and Likens, G. E. 2009. Adaptive monitoring: a new paradigm for long-term research and monitoring. Trends in Ecology \& Evolution, Vol. 24, Issue 9, p482-486.

Lovett, G.M., Burns, D.A., Driscoll, C.T., Jenkins, J.C., Mitchell, M.J. Rustad, L., Shanley, J.B., Likens, G.E., and Haeuber, R. 2007. Who needs environmental monitoring? Frontiers in Ecology and the Environment 5: 253-260.

Margules, C. R., \& Pressey, R. L. 2001. Systematic conservation planning. Nature, 405 (11 May 2001), 243-253. Retrieved from http://www.nature.com/nature/journal/v405/n6783/full/405243a0.html

Meyer, J. L., Paul, M. J., \& Taulbee, W. K. 2005. Stream ecosystem function in urbanizing landscapes. Journal of the North American Benthological Society, 24(3), 602-612. http://doi.org/10.1899/04-021.1

Middleton, J. 2001. The Stream Doctor Project: Community-Driven Stream Restoration. BioScience, 51(4): 293-296.

Nahkeeta Northwest Wildlife Services. 2008. Puget Sound Marine Invasive Species Identification. Puget Sound Marine Invasive Species Volunteer Monitoring Program (MISM) Guide http://vmp.bioe.orst.edu/Documents/mism ID Cards5print.pdf

Nisqually Delta Restoration. 2010. Nisqually Estuary Invertebrate Sampling. http://nisquallydeltarestoration.org/science invertebrates.php

Orr, C.H., Rogers, K.L. and Stanley, E.H. 2006. Channel morphology and P uptake following removal of a small dam. Journal of the North American Benthological Society, 25(3):556-568.

Orr, C.H., Kroiss, S.J., Rogers, K.L. and Stanley, E.H. 2008. Downstream Benthic Responses to Small Dam Removal in a Coldwater Stream. River Research and Applications. 24: 804-822

Otak, Inc. 2013. Bucklin Hill Project: Biological Assessment. http://www.kitsapgov.com/pw/pdf/BA Bucklin Hill 122413 FINAL.pdf

Otak, Inc. 2013. Bucklin Hill Project: Environmental Impact Statement (EIS) Addendum. http://www.bucklinhill.com/pdf/EIS\%20Addendum\%20December\%2018,\%2020 13.pdf

Otak, Inc. 2013. Bucklin Hill Project: Wetland and Stream Assessment Report. http://www.kitsapgov.com/pw/pdf/FINAL\%20Bucklin\%20Hill\%20Wetland\%20St ream\%20Report.pdf

Otak, Inc. 2014. Bucklin Hill Project: Final Stormwater Design. http://www.bucklinhill.com/pdf/DrainageMemo_Nelson_120814.pdf 
Palmer, J. and Nelson, A. 2004. Quality Assurance Project Plan for Carpenter Creek/Appletree Cove Estuary Water Quality Monitoring Program. Stillwaters Environmental Education Center/Cutthroats of Carpenter Creek.

Puget Sound Stream Benthos.2012. Benthic Index of Biotic Integrity.

http://www.pugetsoundstreambenthos.org/About-BIBI.aspx

Puget Sound Partnership. 2009. Puget Sound Action Agenda. Retrieved from www.psp.wa.gov/downloads/AA2009/Action_Agenda_FINAL_063009.pdf

Puget Sound Regional Council. 2015. Puget sound Trends. http://www.psrc.org/assets/2782/trend-d3.pdf?processed=true

Puget Sound Steelhead Technical Recovery Team (PSSTRT). 2013. Identifying historical populations of steelhead within the Puget Sound Distinct Population Segment. Final Review Draft. 149 p.

Rudy, P. and Rudy L.H. 1983. Oregon estuarine invertebrates: an illustrated guide to the common and important invertebrate animals. Washington, D.C.: Fish and Wildlife Service, U.S. Dept. of the Interior. https://scholarsbank.uoregon.edu/xmlui/bitstream/handle/1794/1070/estuarin e invertebrates.pdf?sequence $=3 \&$ isAllowed $=y$

Shoreline Monitoring Toolbox. Washington Sea Grant. Website: wsg.washington.edu/toolbox

Silvertown, J. 2009. A new dawn for citizen science. Trends in ecology \& Evolution, 24 (9), 467-47.1

Smith, J.S. (2009) Winter Steelhead and Chinook and Coho Salmon Life Cycles and Habitat Requirements. Dept. Biological Sciences San Jose State University

Spromberg, J. A., Baldwin, D. H., Damm, S. E., Mclntyre, J. K., Huff, M., Sloan, C. A., Anulacion, B. F., Davis, J. W., Scholz, N. L. 2015. Coho salmon spawner mortality in western US urban watersheds: bioinfiltration prevents lethal stormwater impacts. Journal of Applied Ecology. 2015.

Suquamish Tribe. 2003. Dyes Inlet Estuary Study: Chico, Clear and Barker Estuaries

Suquamish Tribe. 2015. History and Culture. http://www.suquamish.nsn.us/HistoryCulture.aspx

Thoits, P., \& Hewitt, L. 2001. Volunteer Work and Well-Being. Journal of Health and Social Behavior, 42(2): 115-131.

U.S. Department of the Interior, U.S. Geological Survey. 2016. Silverdale, Washington. http://geonames.usgs.gov/apex/f?p=gnispq:3:0::NO::P3 FID:1512662

U.S. Environmental Protection Agency. 1977. Effects of Copper and Zinc on Smoltification in Coho Salmon. Environmental Research Laboratory. Office of Research and Development. 
U.S. Environmental Protection Agency. 2015. National Recommended Water Quality Criteria - Aquatic Life Criteria Table. http://www2.epa.gov/wqc/nationalrecommended-water-quality-criteria-aquatic-life-criteria-table.

U.S. Environmental Protection Agency. 1980. Design Manual Onsite Wastewater Treatment and Disposal Systems. http://nepis.epa.gov/Exe/ZyPDF.cgi/300043XO.PDF?Dockey=300043XO.PDF

U.S. Environmental Protection Agency. 2007. Volunteer Stream Monitoring: A Methods Manual. http://owpubauthor.epa.gov/type/rsl/monitoring/stream index.cfm

U.S. Geological Survey. 2016. pH - Water properties. The USGS Water Science School. http://water.usgs.gov/edu/ph.html

Washington State Department of Ecology. 1999. Pacific Northwest Salmon Habitat Indicators - Snohomish River Basin Pilot Program. https://fortress.wa.gov/ecy/publications/documents/99301.pdf

Washington State Department of Ecology. 2007. WAC 173-201A-200. Fresh water designated uses and criteria. http://www.ecy.wa.gov/programs/wq/swqs/criteriafreshwater/wac173201a 200-temp.html

Washington State Department of Ecology. 2012. Washington State Water Quality Assessment: 303(d)/305(b) Integrated Report. https://fortress.wa.gov/ecy/wats/UIEpaSearch/ApprovedSearchResults.aspx

Washington State Department of Ecology. 2016. Puget Sound Shorelines - History. http://www.ecy.wa.gov/programs/sea/pugetsound/tour/history.html

Washington State Department of Ecology. 2016. Water Quality Assessment Categories. http://www.ecy.wa.gov/programs/wq/303d/WQAssessmentCats.html

Washington State Department of Fish and Wildlife. 2014. Puget Sound Nearshore Ecosystem Restoration Project (PSNERP). http://www.pugetsoundnearshore.org/pugetsound.html

Washington State Department of Fish and Wildlife. 2016. SalmonScape. http://apps.wdfw.wa.gov/salmonscape/map.html

Washington State Department of Fish and Wildlife. 2016. WRIA-15. Stream Catalog. http://docs.streamnetlibrary.org/Washington/DFW/StreamCatalog/15WRIA.pdf

Washington Department of Fish \& Wildlife. 2016. Salmon and steelhead life cycle and habitat information. Habitat Restoration \& Protection. http://wdfw.wa.gov/conservation/habitat/spawningbed protection/lifecycle.ht $\underline{\mathrm{ml}}$ 
Washington Department of Fisheries, Washington Department of Wildlife, and Western Washington Treaty Indian Tribes. 1993. 1992 Washington State Salmon and Steelhead Stock Inventory. http://wdfw.wa.gov/publications/00194/wdfw00194.pdf

Washington (State) Department of Highways. 1968. "Bremerton Freeway Opening First Section". Olympia, WA : Washington State Highway Commission, Dept. of Highways.

Washington State Legislature. 2006. Water Quality Standards for Surface Waters of the State Of Washington: Chapter 173-201A WAC.

http://app.leg.wa.gov/WAC/default.aspx?cite=173-201A.

Wolanski, E. (2007). Estuarine ecohydrology. Amsterdam: Elsevier 
XII. Appendix A - WQM Data Sheet

Measurements taken on (1),$-- / \ldots / \ldots$

Location Site \# (2)

Data collector(s): (3)

\section{ONSITE DATA COLLECTION}

\begin{tabular}{|l|l|}
\hline Time begun: (4) & Time ended: $(5)$ \\
\hline Tide: $(6)$ & Clouds: (7) \\
\hline Wind direction (8) & Wind speed estimation (9) \\
\hline
\end{tabular}

PROBES

\begin{tabular}{|lr|r|}
\hline $\begin{array}{l}\text { Air temperature } \\
\left.140.0^{\circ} \mathrm{F}\right)\end{array}$ & $\left(-5.0\right.$ to $60.0^{\circ} \mathrm{C} / 23.0$ to & $(10)$ \\
\hline $\begin{array}{l}\text { Water temperature } \\
\left.140.0^{\circ} \mathrm{F}\right)\end{array}$ & $\left(-5.0\right.$ to $60.0^{\circ} \mathrm{C} / 23.0$ to & $(11)$ \\
\hline $\mathrm{pH}$ & $(0$ to $14.0 \mathrm{pH})$ & $(12)$ \\
\hline $\begin{array}{l}\text { Conductivity }(\mathrm{EC}) \\
\mu \mathrm{S} / \mathrm{cm})\end{array}$ & $(0.00$ to 20.00 & $(13)$ \\
\hline $\begin{array}{l}\text { Total Dissolved Solids (TDS) } \\
\text { ng/L) }\end{array}$ & $(0.00$ to $10.00 \mathrm{ppt}$ or & $(14)$ \\
\hline
\end{tabular}

\section{CHEMICAL ANALYSIS}

\begin{tabular}{|lc|c|}
\hline $\begin{array}{l}\text { Total Ammonia } \\
(\mathrm{mg} / \mathrm{L})\end{array}$ & $\left(\mathrm{NH}^{3} / \mathrm{NH}^{4}:^{+} 0-8.0 \mathrm{ppm}\right.$ & $(15)$ \\
\hline $\begin{array}{l}\text { Dissolved Oxygen } \\
\text { ppm) }\end{array}$ & $\left(\mathrm{O}_{2:} 0-10 \mathrm{mg} / \mathrm{L}\right.$ or & $(16)$ \\
\hline Nitrates & $\left(\mathrm{NO}_{3}: 0-160 \mathrm{ppm}\right)$ & $(17)$ \\
\hline $\begin{array}{l}\text { Nitrites } \\
(\mathrm{mg} / \mathrm{L}) .)\end{array}$ & $\left(\mathrm{NO}_{2}^{-}: 0-5.0 \mathrm{ppm}\right.$ & $(18)$ \\
\hline
\end{tabular}

\section{MANUAL MEASUREMENTS}

(19) Flow Rate in cubic feet per second (cfs) [cfs = a*b*c/d]

(20) (a) Stream Width (distance across the stream) Unit of measure = meters | feet | inches (circle one)

\begin{tabular}{l|l|l|}
\multicolumn{2}{|c|}{ Flow start (20ft. from site } & Flow end (located at the site marker) \\
\hline marker) & $\underline{(20 \mathrm{a})}$ & $\underline{(20 \mathrm{~b})}$ \\
\hline $\begin{array}{l}\text { Additional } \\
\text { channel: }\end{array}$ & $\underline{(20 \mathrm{c})}$ & $\underline{(20 \mathrm{~d})}$ \\
\hline
\end{tabular}

(21) (b) Stream Depths (water levels) Unit of measure = feet $\mid$ inches (circle one)

\begin{tabular}{|c|c|c|c|c|c|}
\hline & & Main channel & Add channel & Main channel & Add channel \\
\hline West side & start & (21a) & end & $(21 \mathrm{~b})$ & \\
\hline Center & start & (21c) & end & (21d) & \\
\hline East side & start & $(21 \mathrm{e})$ & end & $(21 \mathrm{f})$ & \\
\hline
\end{tabular}




\begin{tabular}{|l|l|l|}
\hline \multicolumn{2}{|l|}{$(23)$ (d) Flow (time in seconds) Main channel } & \\
\hline West side & $\underline{(23 \mathrm{a})}$ & \\
\hline Center & $\underline{\underline{(23 \mathrm{~b})}}$ & \\
\hline East side & $\underline{\underline{(23 \mathrm{c})}}$ & \\
\hline Bugs, Birds, Marine Life, Sediment, Vegetation \& other Observations \\
\hline$\underline{(24)}$
\end{tabular}

\section{Instructions for ONSITE DATA COLLECTION}

(1) Use _MM_/_DD_/_YYYY__- format

(3) Enter the names of all data collectors
I (2) Enter the site number: I, 2, 3, or 4

I (4) and (5) Use the $24 \mathrm{hr}$ format

(6) NOAA tidal predication for Tracyton, WA. (This information is pre-recorded)

(7) Enter None, Light, Partly, Cloudy, Mostly, or Heavy I (8) Enter N, NE, E, SE, S, SW, W, or NW

(9) Enter None, Light, Breezy, Gusty, Moderate, Strong, or Storm

(10) Hold the probe with cap off in the air. Use the ${ }^{\circ} \mathrm{C} \#$ at the bottom of the screen on the red $\mathrm{pH} /$ Temp probe.

(11) Submerge the lower third of the red $\mathrm{pH} / \mathrm{Temp}$ probe in the water. Use the $\#^{\circ} \mathrm{C}$ at the bottom of the screen.

(12) Submerge the lower third of the red $\mathrm{pH} /$ Temp probe in the water. Use the \# at the top of the screen. The reading will commonly range from 7.5 to 8.5.

(13) Submerge the lower third of the blue "Dist" EC/TDS/Temp probe in the water. Confirm the readout is set at $\mathrm{S} / \mathrm{cm}$ (upper right of screen). If not, press the "SET/HOLD" button on the right hand side, below the screen to change the read out. Use the \# at the top of the screen. The reading will commonly range from 0 to $20 \mathrm{~s} / \mathrm{cm}$.

(14) Submerge the lower third of the blue "Dist" EC/TDS/Temp probe in the water. Confirm the readout is set at ppt. If not, press the "SET/HOLD" button on the right hand side, below the screen to change the read out. Use the \# at the top of the screen. The reading will commonly range from 0 to 10 ppt.

(15) Rinse the testing vial with sample water and discard the rinsing water. Add $10 \mathrm{~mL}$ of sample water to the vial. Add 5 drops of ammonia reagent. Cap the vial and swirl to mix. Add 8 drops of Nessler reagent. Then cap the vial and swirl to mix. Pour the contents of the vial into the color comparator, and then wait 5 minutes for color to develop. Compare the sample color to the scale on the comparator and record the value.

(16) Rinse the glass Do bottle 3x, then collect an underwater sample. Set the stopper while the bottle is underwater. On the bank, stabilize the sample on site by adding 5 drops of reagents 1 and 2 . Shake the sample to mix then add 10 drops of reagent 3 . This will preserve the oxygen concentration until the titration is completed at our lab.

(17) Rinse the testing vial with sample water and discard the rinsing water. Add $10 \mathrm{~mL}$ of sample water to the vial. Add packet of Nitrate reagent, cap the vial and shake energetically for 1 minute to mix. Wait 4 minutes for color to develop. Pour the contents of the vial into the color comparator. Compare the sample color to the scale on the comparator and record the value.

(18) Rinse the testing vial with sample water and discard the rinsing water. Add $10 \mathrm{~mL}$ of sample water to the vial. Add packet of Nitrite reagent, cap the vial and swirl for 15 seconds. Wait 6 minutes for color to develop. Pour the contents of the vial into the color comparator. Compare the sample color to the scale on the comparator and record the value. 
(19) Cfs is calculated using the measured (a) stream widths X $20 \mathrm{ft} X$ (b) average of water

levels(depths) $X$ (c) a coefficient based on the streambed sediments $\square$ (d) time in seconds for a float to travel 20ft. (Measurements are collected onsite in steps 20-23, calculations are completed later.)

(20) (a) Use a measuring reel to determine how wide the stream channel is, from east to west, at two locations; Flow start and Flow end.

(20a) Flow start is the stream width measurement that is $20 \mathrm{ft}$. upstream from site marker. Record the distance under the column heading "Main Channel."

(20b) Flow end is the stream width measurement at the site marker. Record the distance under the column heading "Main Channel."

(20c) Site 2 has an additional channel on the west side of the "island". Record the distance across it using a point on this channel that is $20 \mathrm{ft}$ upstream of the site marker.

(20d) Record the distance across the additional channel at Site 2 using a point on this channel that is perpendicular to the site marker.

(21) (b) Stream depths or water levels are measured at six locations. The stream width is visually divided into thirds. Three measurements each are taken across the stream at the Flow start and also at the Flow end locations. Using the measuring rod, record the stream depths at 1/3 of the stream width from westside eastside bank $(21 \mathrm{a} / \mathrm{b})$, at the center of the stream $(21 \mathrm{c} / \mathrm{d})$, and at $1 / 3$ of the stream width from the eastside bank $(21 \mathrm{e} / \mathrm{f})$. Record the depths in the appropriate columns. Repeat this process at Site 2 for the additional channel.

(22) (c) Look at the deepest part of the streambed to determine if it has a muddy or stony (cobbled) appearance. Circle the appropriate choice.

(23) (d) A float will be placed in the water at the start location and allowed to travel by stream power to the flow end where it is captured using the net. A float is released at the start locations where depths measurements were taken in step 21. A timer is started immediately upon release and stopped immediately upon capture. Times are recorded in the appropriate columns based upon the starting point $(23 a-c)$.

(24) Observations of birds, bugs, plants, or other items of interest are recorded in this section.

\section{IN LAB DATA ANALYSIS}

\begin{tabular}{|c|c|}
\hline $\begin{array}{l}\text { Acidity: } \\
\text { 1. Methyl Orange: } \quad \text { (buffering solution } \times 100 \mathrm{mg} / \mathrm{L} \text { or } \mathrm{ppm} \text { (as } \\
\mathrm{CaCO}_{3} \text { ) }\end{array}$ & (25) \\
\hline $\begin{array}{l}\text { 2. Phenolphthalein: } \\
\text { or ppm) }\end{array}$ & $(26)$ \\
\hline $\begin{array}{l}\text { Alkalinity: } \\
\text { 1.Phenolphthalein: } \\
\text { or ppm) }\end{array}$ & (27) \\
\hline $\begin{array}{l}\text { 2. Total Alkalinity: } \\
\mathrm{mg} / \mathrm{L} \text { or } \mathrm{ppm})\end{array}$ & $(28)$ \\
\hline $\begin{array}{l}\text { Carbon Dioxide }\left(\mathrm{CO}_{2}\right) \\
\text { ppm) }\end{array}$ & (29) $50 \mathrm{~mL}$ \\
\hline $\begin{array}{l}\text { Copper }\left(\mathrm{Cu}^{+}\right) \quad \text { (colorimetric assay scale }=0-2.5 \mathrm{mg} / \mathrm{L} \text { or } \\
\mathrm{ppm})\end{array}$ & (30) $25 \mathrm{~mL}$ \\
\hline $\begin{array}{l}\text { Phosphates }\left(\mathrm{PO}_{4}^{-3}\right) \\
\text { ppm) }\end{array}$ & (31) $10 \mathrm{~mL}$ \\
\hline $\begin{array}{l}\text { Salinity } \\
\mathrm{g} / \mathrm{kg} \text { or } \mathrm{ppt})\end{array}$ & (32) $10 \mathrm{~mL}$ \\
\hline (colorimetric assay scale $=0$ to $3.0 \mathrm{mg} / \mathrm{L}$ & (33) $20 \mathrm{~mL}$ \\
\hline
\end{tabular}




\section{Instructions for IN LAB DATA ANALYSIS}

During "In Lab Analysis," colorimetric (figure A) or titration (figure B) methods are used to detect the amount (concentration) of metals and other select chemicals in the water samples collected.

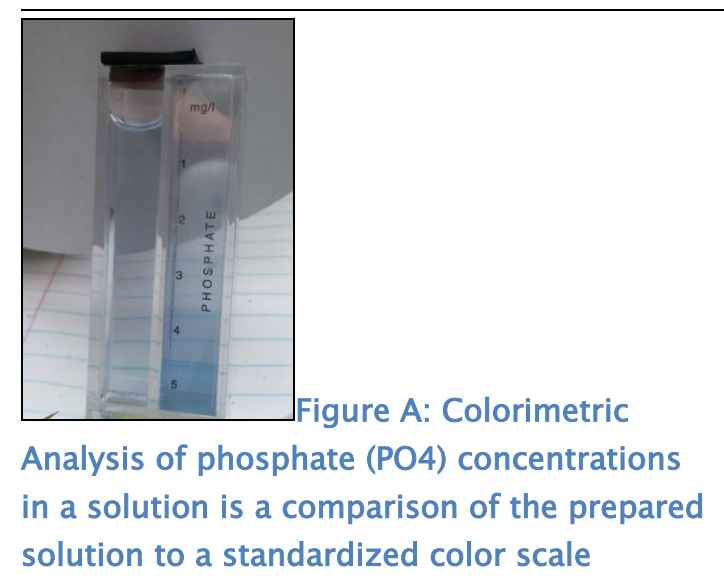

solution to a standardized color scale

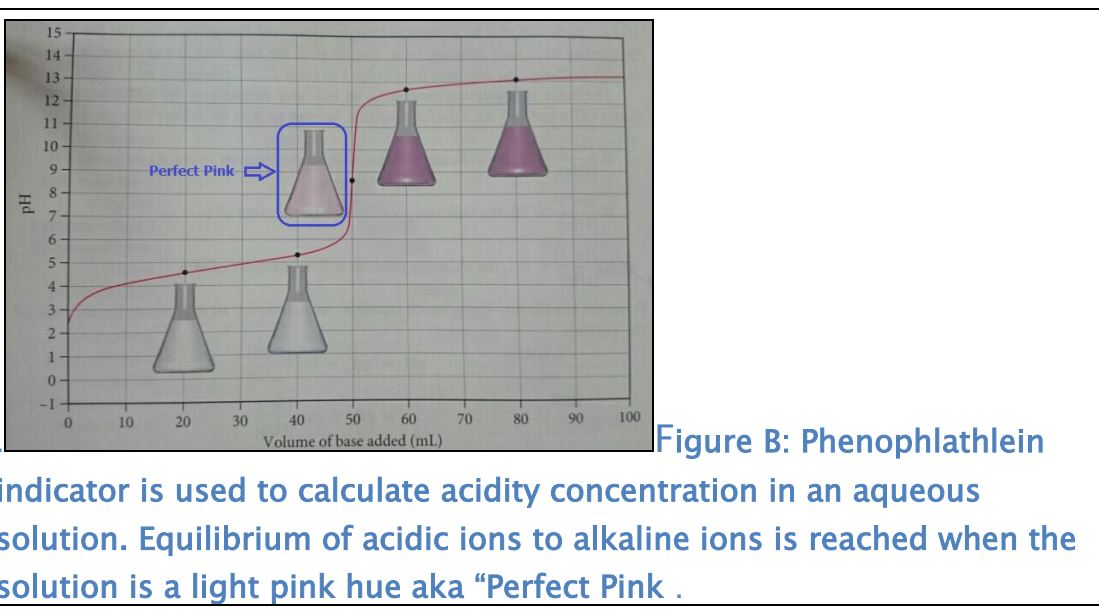

(25) Rinse the testing vial with sample water and discard the rinsing water. Add $25 \mathrm{~mL}$ of sample water to the vial. Add 1 drop of dechlorinating reagent, cap the vial and swirl gently to mix. Add 1 drop of bromophenol blue indicator and swirl. If solution is blue or green, record Methyl Orange Acidity as zero. If yellow, use the titration plunger to uptake $1 \mathrm{~mL}$ of buffering solution (solution will be in the tip of the syringe only). Add 1 drop at a time, swirling to mix after each addition to mix until the solution turns green. The amount of titration solution used is the empty space on the syringe scale. Record the number.

(26) Rinse the testing vial with sample water and discard the rinsing water. Add $25 \mathrm{~mL}$ of sample water to the vial. Add 1 drop of phenolphethalein indicator and swirl. If solution remains colorless, use the titration plunger to uptake $1 \mathrm{~mL}$ of buffering solution (solution will be in the tip of the syringe only). Add 1 drop at a time, swirling to mix after each addition to mix until the solution turns light pink. The amount of titration solution used is the empty space on the syringe scale. Record this number as the Phenolphthalein Acidity concentration.

(27) Rinse the testing vial with sample water and discard the rinsing water. Add $15 \mathrm{~mL}$ of sample water to the vial. Add 1 drop of phenolphethalein indicator and swirl. If solution remains colorless, record as zero. Otherwise use the titration plunger to uptake $1 \mathrm{~mL}$ of buffering solution (solution will be in the tip of the syringe only). Add 1 drop at a time, swirling to mix after each addition to mix until the solution becomes colorless. The amount of titration solution used is the empty space on the syringe scale. Record this number as Phenolphthalein Alkalinity concentration.

(28) Rinse the testing vial with sample water and discard the rinsing water. Add $15 \mathrm{~mL}$ of sample water to the vial. Add 1 drop of bromophenol blue indicator and swirl. If solution is yellow, record Total Alkalinity concentration as zero. If blue or green, use the titration plunger to uptake $1 \mathrm{~mL}$ of buffering solution (solution will be in the tip of the syringe only). Add 1 drop at a time, swirling to mix after each addition to mix until the solution turns yellow. The amount of titration solution used is the empty space on the syringe scale. Record the number.

(29) Rinse the testing vial with sample water and discard the rinsing water. Add $50 \mathrm{~mL}$ of sample water to the vial. Add 1 drop of phenolphethalein indicator and swirl. If solution remains colorless, use the titration plunger to uptake $1 \mathrm{~mL}$ of buffering solution (solution will be in the tip of the syringe only). Add 1 drop at a time, swirling to mix after each addition to mix until the solution 
becomes light pink. The amount of titration solution used is the empty space on the syringe scale. Record this number as Carbon Dioxide $\left(\mathrm{CO}_{2}\right)$ concentration.

(30) Rinse the color comparator with sample water and discard the rinsing water. Add $20 \mathrm{~mL}$ of sample water to the color comparator. Add packet of copper reagent, cap the vial and shake to mix. Wait 45 seconds for color to develop. Compare the sample color to the scale on the comparator and record the value as Copper $\left(\mathrm{Cu}^{+}\right)$concentration.

(31) Rinse the testing vial with sample water and discard the rinsing water. Add $10 \mathrm{~mL}$ of sample water to the vial. Add packet of Phosphate reagent, cap the vial and shake to mix. Wait 1 minute for color to develop. Pour the contents of the vial into the color comparator. Compare the sample color to the scale on the comparator and record the value as Phosphate $\left(\mathrm{PO}_{4}\right)$ concentration.

(32) Rinse the testing vial with sample water and discard the rinsing water. Add $1 \mathrm{~mL}$ of sample water to the vial. Add 1 drop of diphenylcarbazone indicator and swirl. The solution will become violet. Add 1 drop of Nitric Acid at a time until solution turns yellow (usually 1 drop). Use the titration plunger to uptake $1 \mathrm{~mL}$ of buffering solution (solution will be in the tip of the syringe only). Add 1 drop at a time, swirling to mix after each addition to mix until the solution becomes purple again. The amount of titration solution used is the empty space on the syringe scale. Record this number as Salinity concentration.

(33) Rinse the testing vial with sample water and discard the rinsing water. Add $20 \mathrm{~mL}$ of sample water to the vial. Add packet of Zinc reagent, mix with the spoon until dissolved. Pour $10 \mathrm{~mL}$ of the solution into the glass cuvet (up to the mark). Add $0.5 \mathrm{~mL}$ of reagent by means of the syringe. Cap the cuvet and mix for 15 seconds. Wait 3 minutes and 30 seconds for color to develop. Pour the contents of the vial into the color comparator. Compare the sample color to the scale on the comparator and record the value as Zinc $(\mathrm{Zn})$ concentration.

Resources: Hanna Instruments: http://hannainst.com/

\section{Appendix B - Training Manual}

\section{Contents}

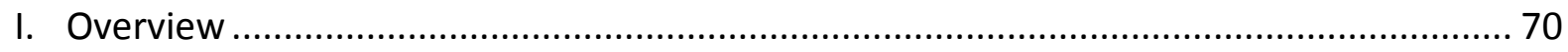

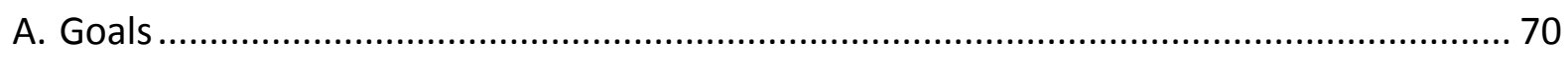

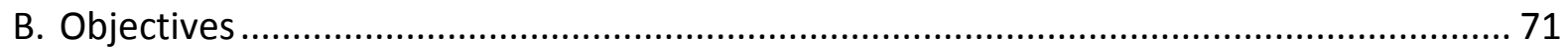

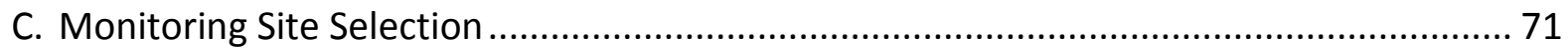

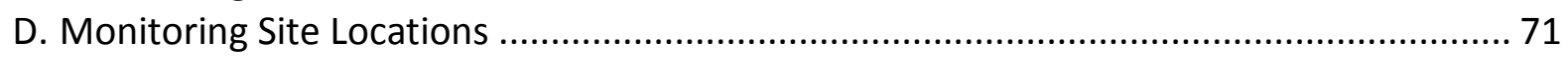

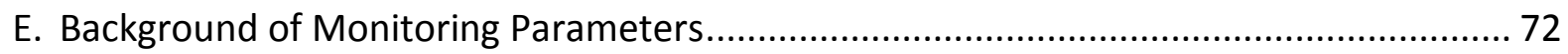

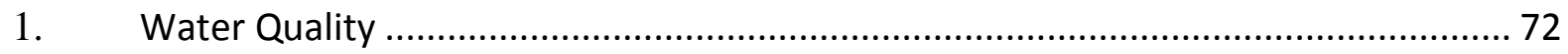

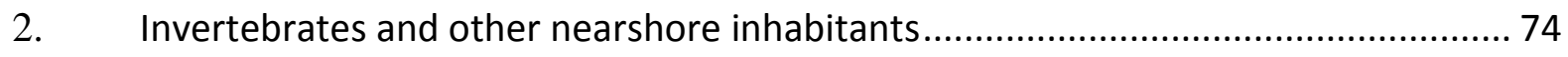

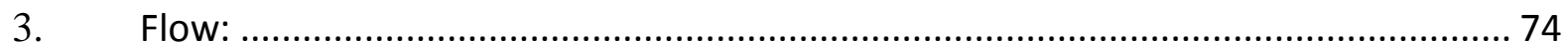

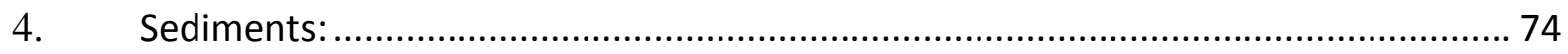

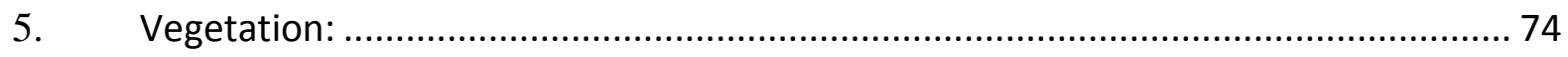

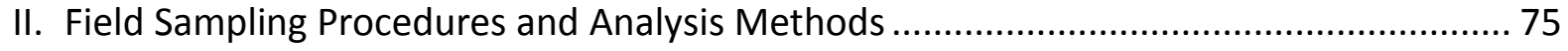

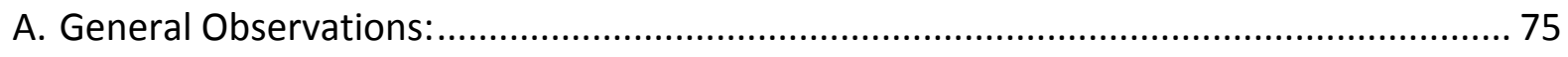

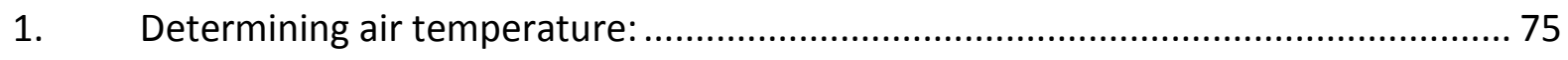

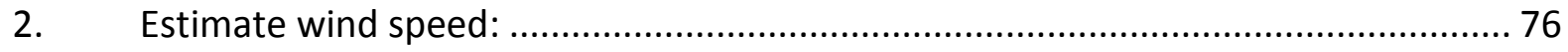

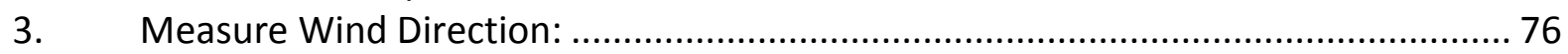

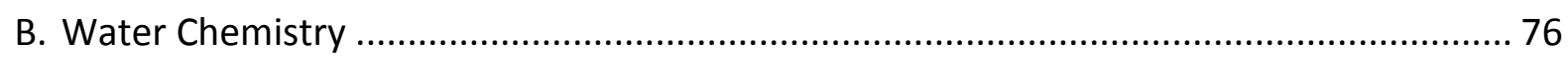

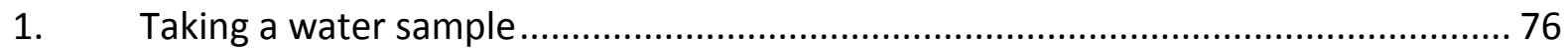

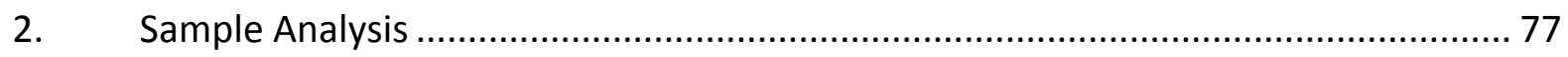




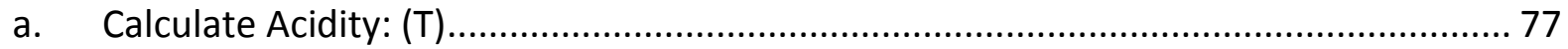

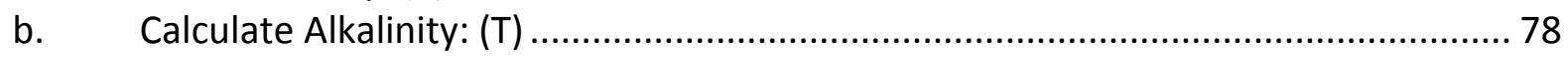

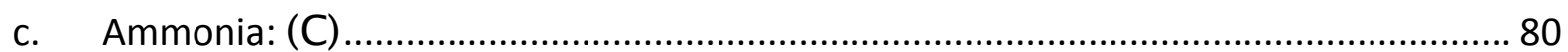

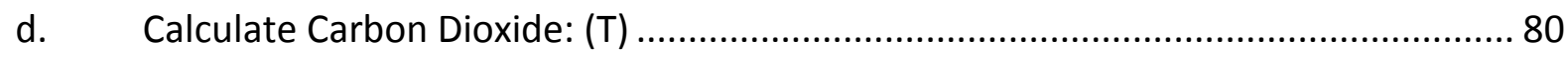

a. Conductivity aka Specific Electrical Conductivity (EC): (D) .................................... 81

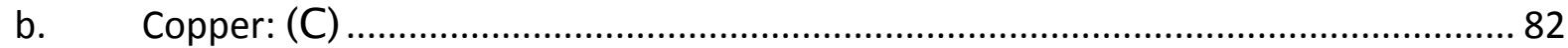

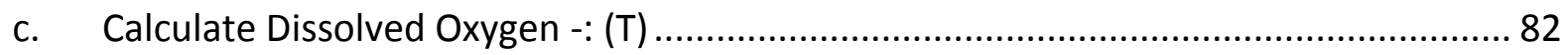

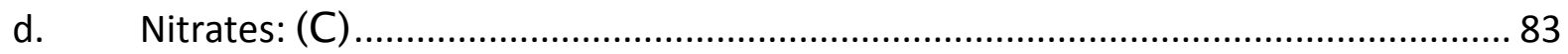

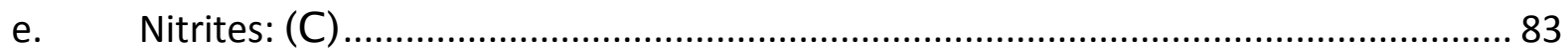

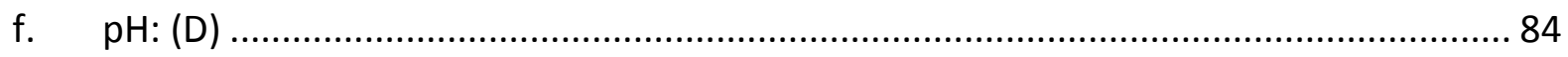

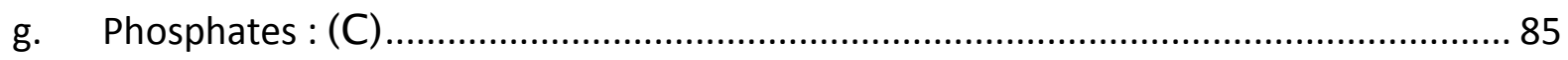

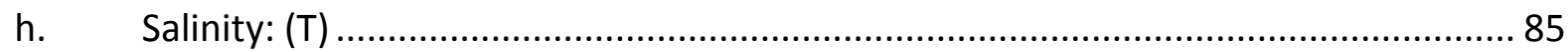

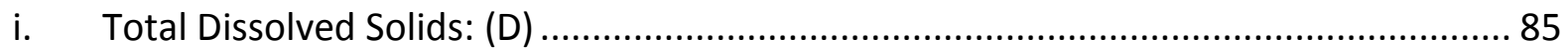

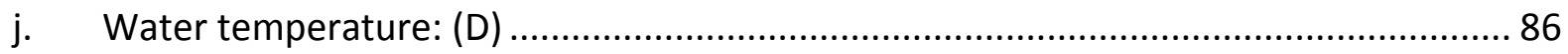

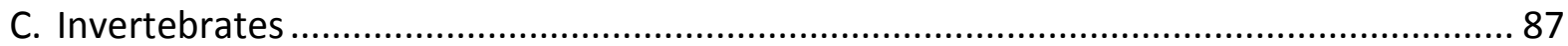

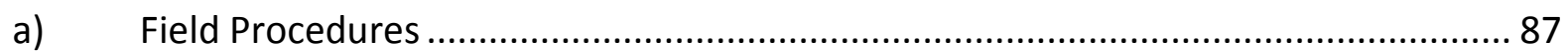

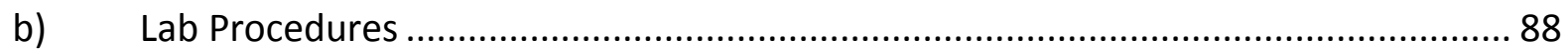

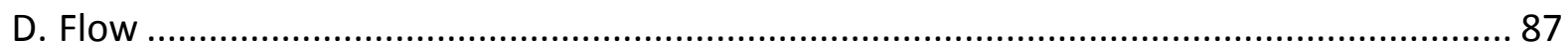

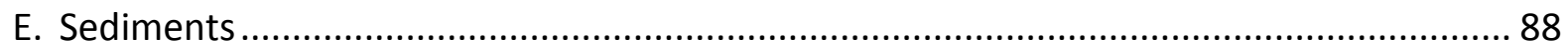

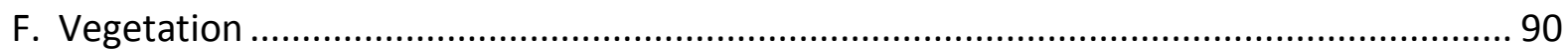

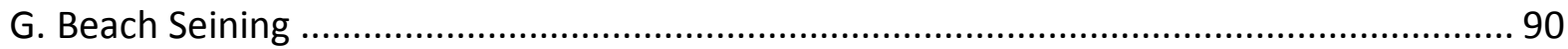

\section{Overview}

Proper balances in the chemical and physical traits in an ecosystem lead to an environment that can support the salmon life cycle. Various physical and chemical characteristics can be used to gauge the feasibility of an estuarine habitat for salmonid use.

\section{Goals}

The goal of this monitoring project is to aid in determining whether habitat has improved for salmonids as a result of the Bucklin Hill Bridge replacement project by:

1. Establishing the baseline or preconstruction conditions of the water quality, vegetation composition, sediment profiles, and macroinvertebrate assemblages.

2. Continue collecting these types of data throughout the construction period and for several years postconstruction, but at least 3 years after the bridge is completed.

3. Educate residents in the watershed regarding salmon habitat to encourage pollution prevention and environmental stewardship.

4. Collect observations that assist in determining if and where adaptive management techniques should be used in the event that salmon habitat is not improving due to the restoration project. 


\section{Objectives}

The objective of this manual is to:

- Provide monitoring protocols that can be used by citizen scientists.

- Train volunteers in basic estuarine habitat monitoring methods.

- Provide volunteers with information on estuary management and restoration.

- Contribute to the State's Marine/Freshwater Water Quality Monitoring Program.

\section{Monitoring Site Selection}

There were four locations selected for observation and data collection. These field locations will be used to characterize the tidally influenced areas of the estuary of Clear Creek/Dyes Inlet (Figure 1). Two sites were selected, south of the existing Bucklin Hill Bridge, which have more marine environmental characteristics (Site 1 and Site 2). The other two sites, with more estuarine features (Sites 3 and 4), are located north of the bridge. By collecting water quality, invertebrate and insect information, along with sediment and vegetation profiles from the four sites along the range from Old Mill Park to the top edge of the salt marsh where the tidal influence diminishes, we can obtain a characterization of habitat conditions of this portion of the watershed.

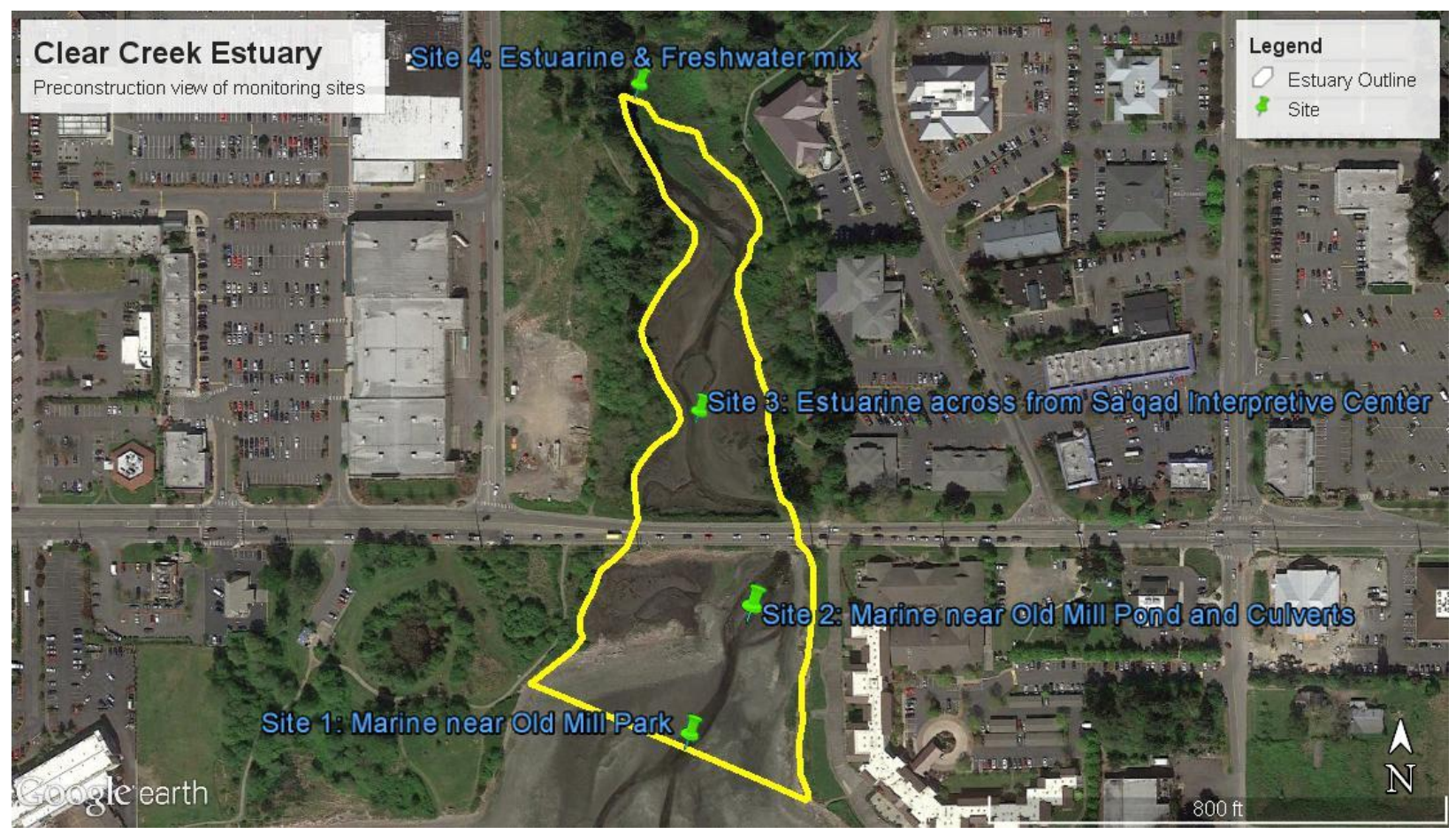

Figure 28: Monitoring Sites on the Clear Creek Estuary include two sites north of the existing culverts and two sites south of them. Courtesy of Google Earth.

\section{Monitoring Site Locations}

To measure changes seen from replacement of the Bucklin Hill Bridge, data will be collected from the four monitoring sites selected to represent the range of habitat in the estuary. The monitoring stations can be located as follows: 
Site1 Old Mill Park (Marine): Access is from the crosswalk over Bucklin Hill Road near Crista Shores Retirement Center. Follow the trail to the light blue interpretive sign. Access the pebble beach by walking northwesterly and aiming for the interpretive sign on the far bank (toward Old Mill Park). Coordinates are Latitude $47^{\circ} 38^{\prime} 58.58^{\prime \prime} \mathrm{N}$, Longitude $122^{\circ} 41^{\prime} 09.66^{\prime \prime} \mathrm{W}(47.649606,122.686016)$.

Site 2 Old Mill Pond (Marine): From Site 1, to the fire hydrant. Access the pebble beachby walking northwesterly and aiming for the outlet of the former millpond. Coordinates are Latitude $47^{\circ} 39^{\prime} 0.23^{\prime \prime} \mathrm{N}$, Longitude $122^{\circ} 41^{\prime} 8.58^{\prime \prime} \mathrm{W}$ (47.6500064, 122.685717).

Site 3 Clear Creek Estuary (Estuarine): Access is from the western side of the creek, almost directly across from the Clear Creek Sa'qad Interpretive Center (red barn). Walk to the Clear Creek trailhead on the western edge of the estuary, then in a northerly direction down the trail to the picnic table. Head in an easterly, diagonal line toward the stream. Walk around the heavier vegetation towards the right, then down to the stream. Coordinates are Latitude $47^{\circ} 39^{\prime} 3.713^{\prime \prime} \mathrm{N}$, Longitude $122^{\circ} 41^{\prime} 9.97^{\prime \prime} \mathrm{W}$ (47.651031, 122.686103).

Site 4 Clear Creek (Estuarine-Freshwater): Access is from the eastern side of the creek, down the hill from the IRS Office on Levin Road in the Business Center. Walk north from the Saq'ad Interpretive Center. Cross over a bridge and continue walking northeasterly until aligned with an aqua colored vent pipe located in the Levin Building lawn. Look to the left for the opening in the trees on the west side of the trail. Follow the informal trail down the hill and along the edge of the bankful width to the second curve. A tree with a light yellow painted square marks the east side of the transit. Walk directly west towards the streambank. Coordinates are Latitude $47^{\circ} 39^{\prime} 8.75^{\prime \prime} \mathrm{N}$, Longitude $122^{\circ} 41^{\prime} 11.45^{\prime \prime} \mathrm{W}$ (47.65265, 122.686561).

\section{Background of Monitoring Parameters}

\section{Water Quality}

The chemical composition of water has an impact on the quality of life the aqueous body can sustain. This monitoring program is designed to capture long term trends in the concentrations of chemicals and physical attributes of the estuary. The chemical analysis includes measurements of nitrogen-based chemicals [ammonia: $\mathrm{NH}_{3} / \mathrm{NH}_{4}$, nitrites: $\mathrm{NO}_{2}$, \& nitrates: $\left.\mathrm{NO}_{3}\right)$, acidity, alkalinity, carbon dioxide $\left(\mathrm{CO}_{2}\right)$, dissolved oxygen (DO), phosphates $\left(\mathrm{PO}_{4}{ }^{3-}\right)$, salinity, and metals $\left(\mathrm{Cu}^{+}, \mathrm{Zn}^{+}\right)$. Other components that can impact chemistry are temperature, electrical conductivity (EC), total dissolved solids (TDS) and $\mathrm{pH}$.

The affects of these compounds/ qualities on aquatic habitat suitability are described as follows:

- Acidity - Acidity or low pH values affect how soluble (dissolvable) other substances, such as metals, are in the water (Temperature and salinity are also factors). Acidity commonly increases via rain and organism decay. Acidity can affect growth rates of fish, plankton production, and shell production for invertebrates.

- Alkalinity - Alkalinity is the ability of water to neutralize an acid -it's not the same as being a base or alkaline substance. A more accurate term is acid neutralizing capacity (ANC). The ability or capacity to neutralize an acid reduces $\mathrm{pH}$ fluctuations from inputs such as rainfall or wastewater. 
- Carbon dioxide $\left(\mathrm{CO}_{2}\right)$ : Stagnant/polluted waters can create more $\mathrm{CO}_{2}$ which in higher amounts can make water corrosive \& toxic to aquatic organisms through its transformation to carbonic acid.

- Copper $\left(\mathrm{CU}^{+}\right)$- Trace amounts of copper are a beneficial factor in plant metabolism. Large quantities however can be detrimental to plants and fish. In salmon, high concentrations may interfere with the ability to of adults to navigate to their natal streams. In juveniles copper can affect osmoregulation (the ability to maintain a balance of salts to chloride levels in fresh and saltwater) and growth. It also can impair their ability to transform into smolts, therefore the ability to transition to life in a saltwater environment.

- Density - Density is related to salinity levels. Relative density = specific gravity. Specific gravity is a method for estimating the number of ions in a volume of water. Fish relay on a constant specific gravity or density within their environment in order to regulate ions in their bodies. In addition, currents are formed through the sinking and rising of various densities of water. Density plays a role in the upwelling of nutrients such as phosphates and nitrogen toward the surface where plants, invertebrates and smaller fish can utilize them.

- Dissolved oxygen (DO) - Oxygen dissolved in water is essential to the growth and development of aquatic life. Phytoplankton and macro-algae produce oxygen through photosynthesis. Bacteria, invertebrates, and fish consume the oxygen (through cellular respiration). Rapidly moving, cooler water, a common condition in late fall through spring, tends to contain a lot of dissolved oxygen (DO). Calm and warmer water, such as often occurs in summer and early fall, contains less. Reduced levels can create lethargy in aquatic biota. Washington State uses DO as an indicator of salmonid habitat suitability. If DO decreases below water quality standards, fish can begin to die.

- Electrical conductivity $(E C)^{1}$ - Measure of the amount of electricity the water can conduct due to the motion of electrically charged particles (ions) in it. A companion measurement is Total Dissolved Solids (TDS) which is the measure of the total ions in solution. Conductance gives a good idea of the amount of dissolved material in the water which can affect the suitability of water for beneficial uses. High specific conductance indicates high dissolved-solids concentration. At higher levels, drinking water may have an unpleasant taste or odor or may even cause gastrointestinal distress. Pure water, such as distilled water, will have a very low specific conductance, and sea water will have a high specific conductance.

- Nitrates $\left(\mathrm{NO}_{3}\right)$ - Nitrates are formed when oxygen replaces nitrogen ions in ammonia compounds. This nitrogen compound is bio-available; i.e. plants can readily absorb it. Excessive amounts can fuel algal blooms which in turn can reduce DO levels.

- Nitrites $\left(\mathrm{NO}_{2}\right)$ - Nitrites are formed through biological decomposition as an intermediate state during the transition of ammonia to nitrates.

- $\quad p H$ - The $\mathrm{pH}$ level affects the solubility (amount that can be dissolved in the water) and biological availability (amount that can be utilized by aquatic life) of chemical components such as nutrients (ex: phosphorus and nitrogen) and heavy metals (ex: copper and zinc). Washington State uses $\mathrm{pH}$ as an indicator of salmonid habitat suitability. A neutral range is most suitable to aquatic life ( 6.5-9 units).

- Phosphates $\left(\mathrm{PO}_{4}{ }^{3-}\right)$ - Phosphates stimulate growth of marine plants and planktonic species which are food sources for marine fish. It is produced naturally by the weathering (breakdown) of rocks. It also enters aquatic systems from human sources such as fertilizer runoff and cleaning products. Excessive amounts can lead to algal blooms which can lead to low DO levels.

\footnotetext{
${ }^{1}$ Specific Conductance, USGS
} 
- Salinity - Salinity is the amount of dissolved salts in water. A salt is an ionic compound (positively or negatively charged) that is a result of the neutralization of an acid and a base ( $\mathrm{pH} \sim 7.0-8.5)$. Salinity levels in an aquatic environment affect the particular species that can live in it. Not only does it affect osmoregulation (control of internal salt levels), too much salt can increase the $\mathrm{pH}$ level. Freshwater generally has a low salinity (<1ppt) while seawater is generally about $35 \mathrm{ppt}$. Mixed (brackish aka estuarine) fresh and salt water will range into between the two values.

- Temperature - Water temperature affects the concentration and activity of ions in water, particularly the reactivity of chemicals and metals. In the Puget Sound low land streams, such as Clear Creek, most aquatic life (fish and insect larvae) is adapted to life in cooler waters. Cooler waters hold greater quantities of dissolved oxygen. Washington State uses temperature as an indicator of salmonid habitat suitability. "Temperature can affect embryonic development; juvenile growth; adult migration; competition with non-native species; and the relative risk and severity of disease." (WA Dept of Ecology).

- Total ammonia $\left(\mathrm{NH}_{3}\right.$ \& $\left.\mathrm{NH}_{4}\right)$ - Most streams do not naturally have large concentrations of biologically available nutrients (ex: ammonia, nitrates) and what is available generally would be absorbed by estuarine plants (ex: salt marsh grasses). High levels of ammonia or nitrates above an amount absorbable by aquatic life generally indicate an human source although wildlife can also create excess amounts.

- $\operatorname{Zinc}\left(\mathrm{Zn}^{+}\right)$- Excessive amounts of zinc may interfere with zooplankton growth. This can ultimately reduce food sources for salmon.

\section{Invertebrates and other nearshore inhabitants}

Invertebrates are a valuable food source for juvenile salmon. Fish such as herring and shiner perch support dietary needs of outward migrating salmon. Determining whether there is an adequate food supply for juvenile salmon using the estuary as a rearing space provides evidence of habitat suitability.

\section{Flow:}

Flow can serve as an indicator of exchange rates of nutrients and sediment movement rates. The physical characteristics of -streamflow represent the stream's sediment carrying power (capacity). High flow rates can destabilize stream banks and trigger erosion. Low flow rates may lead to stagnation.

\section{Sediments:}

Sediment composition affects the types of invertebrates, avian species, and spawning forage fish using the area. Salmonids prefer gravelly sediments in a stream over silted streambeds.

\section{Vegetation:}

Both aquatic and terrestrial plants provide critical components of suitable salmon habitat. Terrestrial vegetation can provide a temperature refuge (stream shading) for juveniles that are rearing in the stream and estuary. Shading also provides camouflage for migrating fish. Downed vegetation such trees and large woody shrubs can also aid salmon by forming deeper pools and protective barriers to diving predators. Aquatic vegetation supports habitat and/or nutrients for invertebrates that can in turn provide a food source for juvenile salmon. 


\section{Field Sampling Procedures and Analysis Methods}

Procedures follow recommendations in the Puget Sound Ecosystem Monitoring Program (PSEMP) Shoreline Monitoring Toolbox Protocols and the EPA Volunteer Water Quality Monitoring Manual to ensure high quality data are collected to help to track estuarine water quality trends, sediment profiles, and types of invertebrates found in the tidally influenced Clear Creek estuary.

\section{A. General Observations:}

Visual assessment of the monitoring site can provide invaluable information and make interpretation of other data easier and more meaningful. Visual assessment is simply observing the environmental conditions at the site and recording them. Make of note of birds or other wildlife seen in the area on the datasheet in the final row of the onsite section. Also record any unusual conditions such as the color of the water, presence of debris or oil, recent shoreline erosion, fish kills, and other notable conditions.

At your sample site, measure the air temperature, wind direction and wind speed prior to water sampling. For wind speed, estimate its strength using Table 1: Wind Speed Characteristics.

\section{Determining air temperature:}

The instrument used is the HI98127 $\mathrm{pHep}^{\circledR} 4 \mathrm{pH} /$ Temperature Tester.

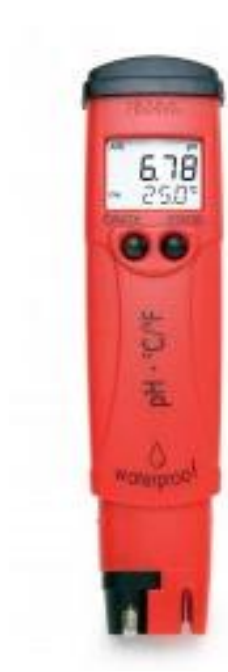

Figure 29: $\mathrm{pH} /$ Temperature Probe
To turn the meter on and check the battery status: Press and hold the /MODE button until the LCD lights up. All the used segments on the LCD will be visible for 1 second (or as long as the button is pressed), followed by the percent indication of the remaining battery life (E.g. \% 100 BATT). Taking measurements: Hold the uncapped electrode in the air The measurements should be taken when the stability symbol $\square$ on the top left of the LCD disappears.

The secondary LCD shows the temperature of the sample

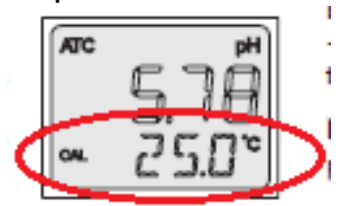

I Figure 30: Secondary LCD Reading

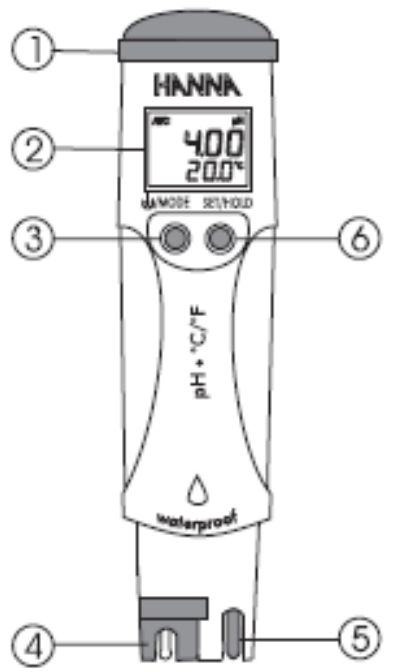

. Batiery compartment

2. Liquid Crystal Desplay (LCD)

3. ON/OFF/MODE bution

4. HI $73127 \mathrm{pH}$ electrode

5. Temperature sensor

6. SET/HOLD bution

Figure 31: Functional diagram of HI98127

To freeze the display: While in measurement mode, press the SET/HOLD button. HOLD appears on the secondary display and the reading will be frozen on the $L C D$ (E.g.pH 5.78 HOLD). Press any button to return to normal mode. To turn the meter off: While in normal mode, press the /MODE button; OFF will appear on the secondary display. Release the button. 


\section{Estimate wind speed:}

Use the descriptions in Table 1 to determine wind speed. Record the numeric value on the data sheet.

\begin{tabular}{|l|l|l|}
\hline knots & $\begin{array}{l}\text { Organization } \\
\text { Description }\end{array}$ & Effects Observed \\
\hline 1 & Calm & Calm \\
\hline \hline 2 & light breeze & $\begin{array}{l}\text { Smoke drift indicates wind direction; vanes do not move } \\
\text { Wind felt on face; leaves rustle; vanes begin to move }\end{array}$ \\
\hline 3 & moderate & $\begin{array}{l}\text { Dust, leaves, and loose paper raised up; small branches } \\
\text { move }\end{array}$ \\
\hline 5 & strong & Larger branches of trees in motion; whistling heard in wires \\
\hline 5
\end{tabular}

\section{Measure Wind Direction:}

Record the wind direction using your compass (record the direction the wind is coming from). In light, unsteady winds, you may have trouble judging wind direction - try tying a piece of ribbon or yarn to a pole or other upright object at your site.

\section{B. Water Chemistry}

Chemical analyses include taking a water sample to measure Acidity, Alkalinity, Ammonia, Carbon Dioxide, Conductivity, Copper, Dissolved Oxygen, Nitrates, Nitrites, Phosphorus, Salinity and Zinc. In addition digital probes are used to collect data for $\mathrm{pH}$, water temperature and total dissolved solids concentrations.

The following information is excerpted from various sources but, generally are taken from the assay and probe manufacturer. The descriptions provide background on the parameter's value in water quality assessment and instruction for collecting and analyzing the data.

\section{Taking a water sample}

Submerge the bottle upstream from where you are standing at the deepest part of the stream (thalwag).

Turn the bottle away from the current and scoop in a downstream direction.

1. The bottle will be labeled with the site number.

2. Remove the cap from the bottle just before sampling. Avoid touching the inside of the bottle or the cap. If you accidentally touch the inside of the bottle, use another one.

3. Wading. Try to disturb as little bottom sediment as possible. In any case, be careful not to collect water that has sediment from bottom disturbance. Stand facing upstream. Collect the water sample on your upstream side, in front of you. You may also tape your bottle to an extension pole to sample from deeper water.

Boat. Carefully reach over the side and collect the water sample on the upstream side of the boat.

4. Hold the bottle near its base and plunge it (opening downward) below the water surface. If you are using an extension pole, remove the cap, turn the bottle upside down, and plunge it into the water, facing upstream. Collect a water sample 8 to 12 inches beneath the surface or mid-way between the surface and the bottom if the stream reach is shallow.

5. Turn the bottle underwater into the current and away from you. In slow-moving stream reaches, push the bottle underneath the surface and away from you in an upstream direction.

6. Leave a 1-inch air space (Except for DO and nitrogen compound samples). Do not fill the bottle completely (so that the sample can be shaken just before analysis). Recap the bottle carefully, remembering not to touch the inside. 
2. Sample Analysis Data is analyzed in one of three ways:

1) Digital probes (D) - Method is automated. LCD screens provide readouts that are directly recorded

2) Colorimetric analysis (C): Method used to measure the concentration of a specific element or component by adding a reactive ingredient (reagent) to the solution then visually comparing the resulting color to a predefined scale (standard) of that particular element or compound (figure $6)$. Tests by colorimetric process are marked with $(\mathrm{C})$.

3) Titration ( $T)$ : Method used to determine the concentration of a substance in a solution by adding a reactive ingredient (indicator) to the solution and stirring well. Then an additional known solution (buffer or titrant reagent) is added one drop at a time until the reaction between the two solutions is complete. A complete reaction (equilibrium or endpoint) is indicated by a color change in the solution (figure 7). The volume of buffering solution used to change the color is recorded. This value will be multiplied by the applicable factor to calculate the concentration amount. Tests by titration are marked with $(\mathrm{T})$.

Figure 33: Colorimetric Analysis of phosphate $\left(\mathrm{PO}_{4}\right)$ concentrations in a solution is a comparison of the prepared solution to a standardized color scale.

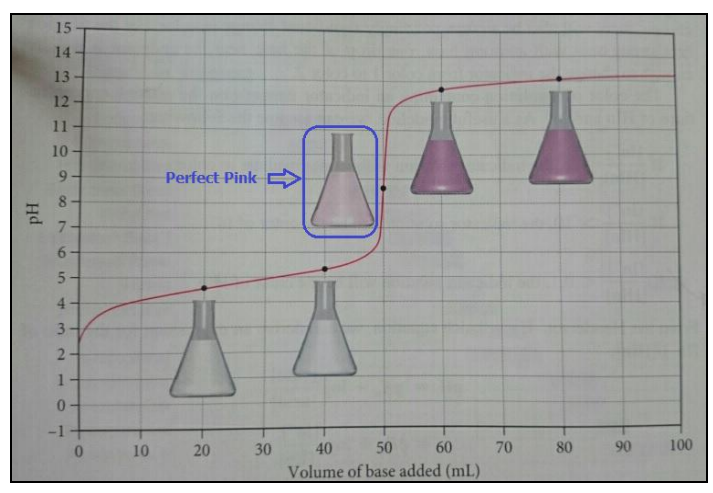

Figure 34: Phenophlathlein indicator is used to calculate acidity concentration in an aqueous solution. Equilibrium of acidic ions to alkaline ions is reached when the solution is a light pink hue aka "Perfect Pink."

\section{a. Calculate Acidity ${ }^{2}:(T)$}

Much aquatic life is sensitive to $\mathrm{pH}$ levels and will thrive within more neutral ranges. Acid added to a stream would cause an immediate change in the $\mathrm{pH}$. In determining the concentration or amount of acid (free hydrogen ions) in the water sample, a diluted sodium hydroxide is used as the titrant or buffering solution. Strong acid contribution to the sample is known as methyl orange acidity. Total acidity is caused by both mineral and organic acids and is called phenolphthalein acidity. 


\section{(1) Determination of Methyl Orange Acidity}

1. Rinse the small vessel with sampled water, fill to the $5 \mathrm{~mL}$ mark and add the cap.

2. Add 1 drop of Dechlorinating reagent through the cap port and mix by carefully swirling the vessel in tight circles.

3. Through the cap port, add 1 drop of Bromophenol Blue indicator and mix. If the solution is green or blue, then record the methyl orange acidity as zero.

4. Proceed with the procedure for the determination of phenolphthalein acidity. If the solution is yellow proceed with the next step (see Determination of Phenolphthalein Acidity: step 3)

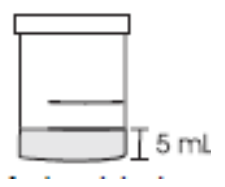

Figure 35: Fill plastic vessel (vial) to $5 \mathrm{~mL}$.

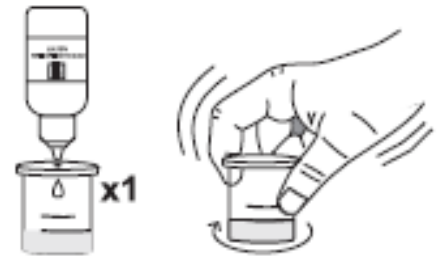

Figure 36 Adding indicator and then swirling to mix

\section{(2) Determination of Phenolphthalein Acidity}

1. Rinse the lage vessel with water sample, fill to the $25 \mathrm{~mL}$ mark and add the cap

2. Through the cap port, add 1 drop of Phenolphthalein indicator and mix. If the solution turns red or pink, then the solution is alkaline and an alkalinity test must be carried out (see Calculating Alkalinity). If the solution remains colorless, proceed to next step.

3. Push the plunger of titration syringe the completely into the syringe. Place the pipet tip securely on the lower end of the syringe. Insert tip into $\mathrm{HI} 3820-0$ solution and pull the plunger out until the lower edge of the plunger seal is on the $0 \mathrm{~mL}$ mark of the syringe.

4. Place the syringe tip into the cap port of the plastic vessel and slowly add the titration solution a drop at a time, swirling to mix after each drop. Continue adding titration solution until the solution in the plastic vessel turns pink.

5. Read off the milliliters of titration solution from the syringe scale and multiply by 100 to obtain Phenolphthalein Acidity in mg/L (ppm) CaCO3.
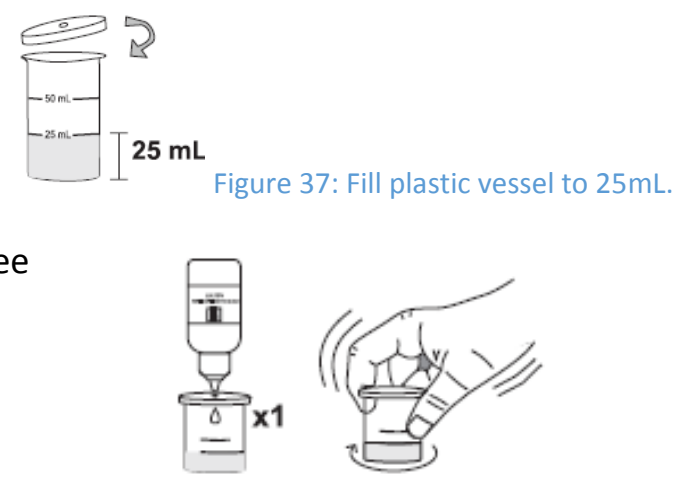

Figure 38; Adding indicator and then swirling to mix

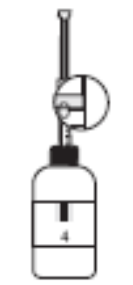

Figure 39: Filling pipet with buffering solution

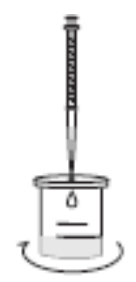

Figure 40:

Titrating adding titration solution

b. Calculate Alkalinity ${ }^{3}:(T)$

Alkalinity is a measure of the capacity of water to neutralize acids. Alkalinity can be measured as Phenolphthalein Alkalinity and Total Alkalinity. Alkaline compounds in the water, such as bicarbonates, carbonates, and hydroxides, remove hydrogen $\left(\mathrm{H}^{+}\right)$ions by combining with the hydroxide $\left(\mathrm{OH}^{-}\right)$ions to make new compounds. This lowers the acidity of the water (increases $\mathrm{pH}$ ).

\footnotetext{
${ }^{3}$ \& $\underline{\text { Hanna Instruments HI3811 }}$
} 


\section{(1) Determination of Phenolphthalein Alkalinity}

1. Rinse the vessel with water sample, fill to the $15 \mathrm{~mL}$ mark and add the cap

2. Through the cap port, add 1 drop of Phenolphthalein indicator and mix. If the solution turns red or pink, then the solution is acid and an acidity test must be carried out (see Calculate Acidity). If the solution remains colorless, proceed to next step

3. Take the titration syringe and push the plunger completely into the syringe. Insert tip into $\mathrm{HI} 3811-0$ solution and pull the plunger out until the lower edge of the plunger seal is on the $0 \mathrm{~mL}$ mark of the syringe.

4. Place the syringe tip into the cap port of the plastic vessel and slowly add the titration solution one drop at a time, swirling to mix after each drop. Continue adding titration solution until the solution in the plastic vessel turns pink.

5. Read off the milliliters of titration solution from the scale on the syringe and multiply by 100 to find the Phenolphthalein alkalinity as $\mathrm{mg} / \mathrm{L}$ (ppm) of $\mathrm{CaCO}$.

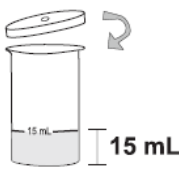

Figure 41: Fill plastic vessel to $15 \mathrm{~mL}$

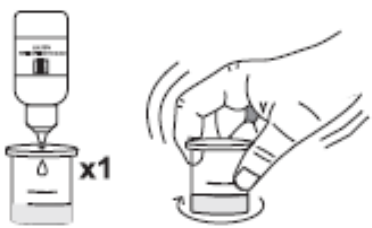

Figure 42 Adding indicator and then swirling to mix
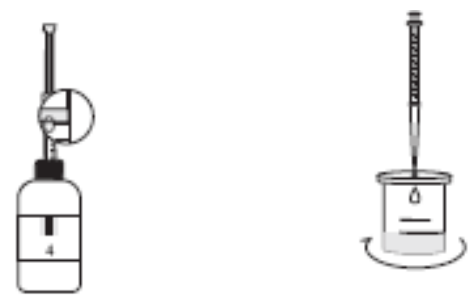

\section{Figure 43: Filling \\ pipet with \\ buffering solution}

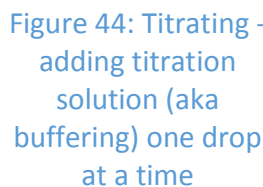

(2) Determination of Total Alkalinity:

1. Rinse the vessel with water sample, fill to the $15 \mathrm{~mL}$ mark and place the cap on the vial.

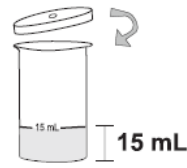

2. Through the cap port, add 1 drop of Phenolphthalein indicator and mix. If the solution turns red or pink, then the solution is acid and an acidity test must be carried out (see Hanna Alkalinity Test Kit . HI 3811). If the solution remains colorless, proceed to next step

3. Take the titration syringe and push the plunger completely into the syringe. Insert tip into $\mathrm{HI} 3811-0$ solution and pull the plunger out until the lower edge of the plunger seal is on the 0 $\mathrm{mL}$ mark of the syringe.

4. Place the syringe tip into the cap port of the plastic vessel and slowly add the titration solution dropwise, swirling to mix after each drop. Continue adding titration solution until the solution in the plastic vessel turns pink. .

5. Read off the milliliters of titration solution from the syringe scale and multiply by 500 to obtain $\mathrm{mg} / \mathrm{L}$ (ppm) CaCO3.

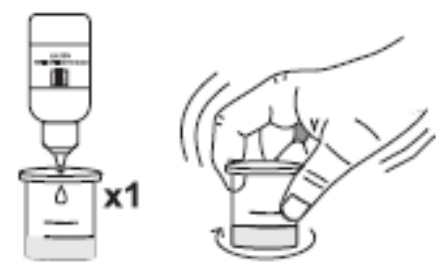

Figure 46: Adding indicator and then swirling to mix
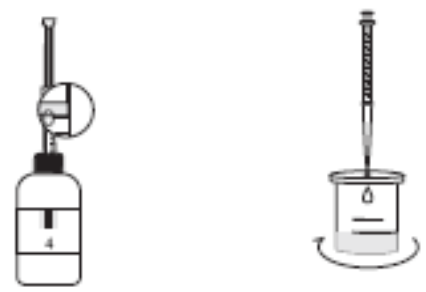

Figure 47: Filling pipet and titrating 
c. Ammonia ${ }^{4}:(C)$

1. Rinse the plastic vessel with water sample, fill to the $10 \mathrm{~mL}$ mark.

2. Add 2 drops of Ammonia reagent (reagent 1) for Fresh Water,

3. Place the cap on the vial and mix by carefully swirling the vessel.

4. Add 8 drops of Nessler reagent (reagent 2), replace the cap and mix by carefully swirling the vessel.

5. Remove the cap and transfer the solution into the color comparator cube. Wait for 5 minutes to allow color to develop.

6. Determine which color matches the solution in the cube, and record the results in $\mathrm{mg} / \mathrm{L}$ (or ppm) $\mathrm{NH}_{3}-\mathrm{N}_{4}$.

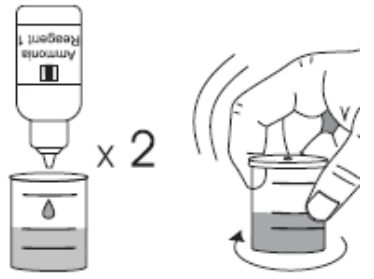

Figure 49 Add reagent 1 to $10 \mathrm{~mL}$ sample. Swirl to mix

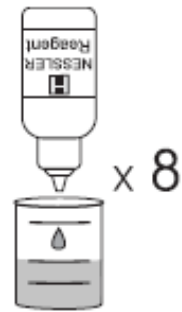

Figure 50:

Add Nessler reagent and then swirl to mix

7. It is better to match the color with a white sheet at about $10 \mathrm{~cm}$ behind the comparator.

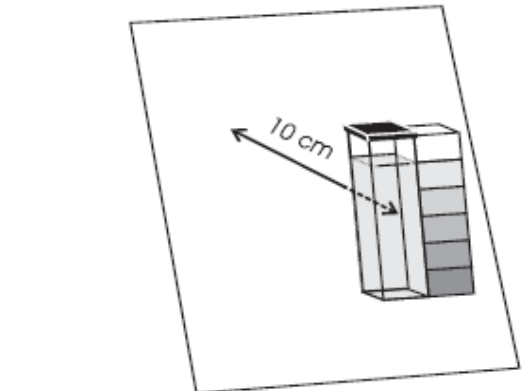

Figure 48 Hold comparator cube in front of white paper to distinguish color more easily

\section{d. Calculate Carbon Dioxide ${ }^{5}$ (T)}

1. Rinse the plastic vessel with water sample; fill to the 50 $\mathrm{mL}$ mark.

2. Add 1 drop of Phenolphthalein indicator mix carefully swirling the vessel in tight circles. If the solution turns pink or red, then record as $0 \mathrm{mg} / \mathrm{L} \mathrm{CO2}$. If the solution remains colorless, continue to the next step.

3. Add the pipet tip to the titration syringe.

4. Push the plunger completely into the syringe, then

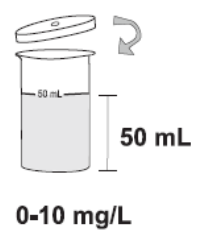

Figure 51 Fill vessel to $50 \mathrm{~mL}$ with sample

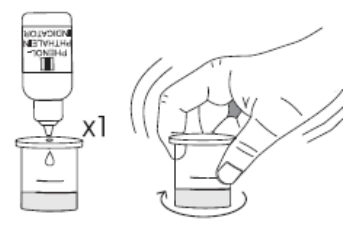

Figure 52: Adding indicator and then swirling to mix 
insert the tip into $\mathrm{HI} 3818-0$ solution and pull plunger out until the lower edge of the plunger seal is on the 0 $\mathrm{mL}$ mark of the syringe. The solution will only fill the pipet tip.

5. Slowly add the titration solution one drop at a time and swirl to mix after each drop. Continue adding drops of the titration solution until the solution in the plastic vessel turns pink.

6. Record the milliliters of titration solution used and multiply by 10 to calculate the ppm (mg/L) of $\mathrm{CO}_{2}$.

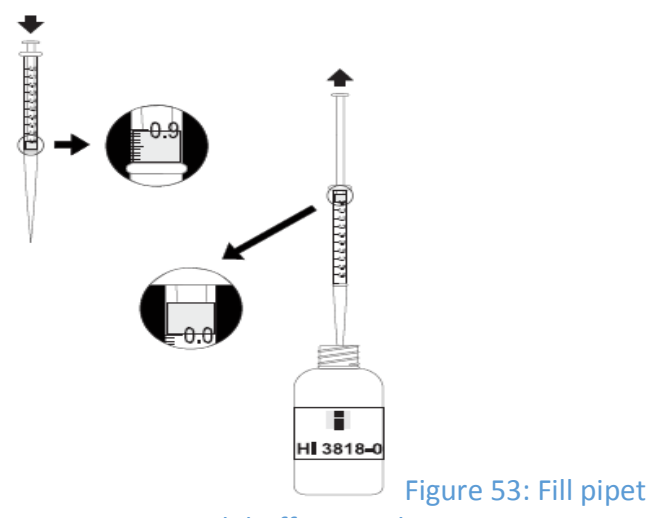

with buffering solution

a. Conductivity aka Specific Electrical Conductivity (EC): (D)

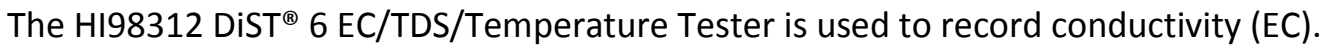

Turning on the probe: Press and hold the same button "/MODE" for 2-3 seconds. All the used segments on the LCD will be visible for a few seconds, followed by a percent indication of the remaining battery life (E.g. $\% 100$ BATT).

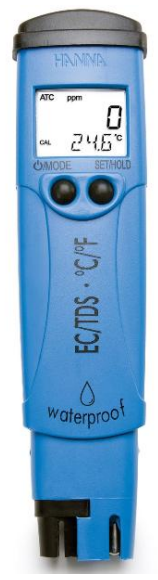

Figure 54: HI98312 DiST ${ }^{\circledR} 6$ EC/TDS/Temperature Tester 
Taking measurements: Submerge the probe in the water..

Confirm that the unit is ppt in the LCD section - labeled 2.

Select the TDS reading mode with the SET/HOLD button (6)

The measurements should be taken when the stability symbol $\square$ on the top left of the LCD disappears.

The TDS value (automatically compensated for temperature) is shown on the primary (larger) LCD at the tops of the screen while the secondary (smaller, lower levels) LCD shows the temperature of the sample.

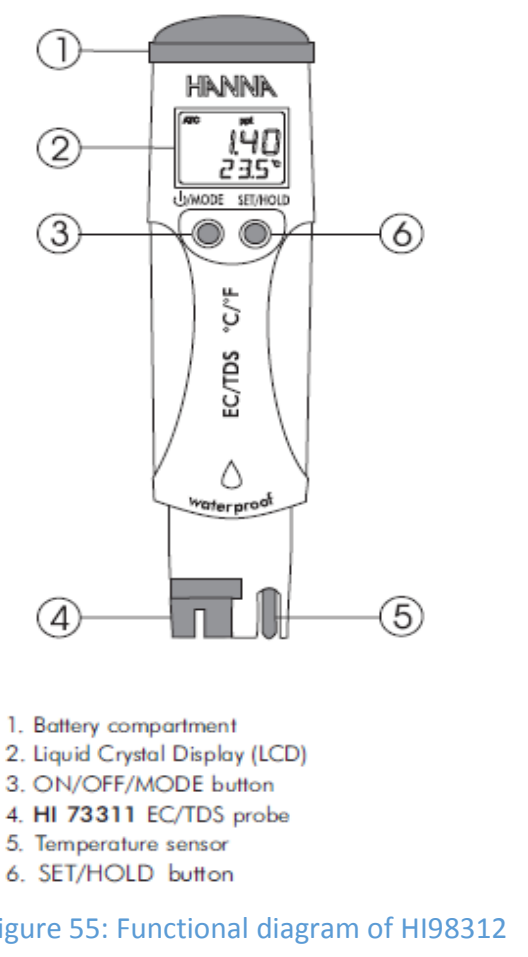

b. Copper $^{6}:(C)$

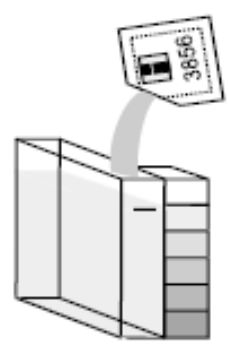

Dissolved copper concentrations are determined using colorimetric analysis. The amount of color that develops relates to the amount of copper present in the water sample.

1. Fill the "comparator" vessel with sampled water to the $25 \mathrm{~mL}$ mark.

2. Add the reagent, cap the comparator and invert it several times to mix.

3. Wait 45 seconds for color to develop, and then compare the sample color to the scale on the right hand side of comparator.

4. Record the value on the datasheet.

c. Calculate Dissolved Oxygen $-^{7}:(T)$

A modified Winkler method for DO is uses steps to collect and stabilize the oxygen concentration while in the field and then titration to calculate oxygen concentration is completed at the lab.

\section{In the Field}

Rinse the glass bottle 3 times with water sample and fill to overflow while it is submerged. Insert stopper and ensure that a small part of the sample spills over.

1. Out of the stream, remove the stopper and add 5 drops each of Manganous Sulphate Solution (reagent 1) and Alkali-Azide Reagent (reagent 2).

2. Carefully stopper the bottle again and ensure that a part of the sample spills over. This is to make sure that no air bubbles have been trapped inside, which would corrupt the reading.

3. Invert several times the bottle. The sample becomes yellow to amber in color. A flocculent precipitate (semi-solid clumping) will form if oxygen is present.

4. Let the sample stand and the flocculent precipitate will start to settle.

5. After 2 minutes, add 10 drops of Sulphuric Acid Solution (reagent 3). 
6. Re-stopper the bottle and invert it until all particulate material is dissolved.

b) At the Lab

1. Rinse the plastic vessel with the solution in the bottle; fill to the $5 \mathrm{~mL}$ mark

2. Add 1 drop of Starch Indicator (reagent 4) and mix by carefully swirling the vessel in tight circles. The solution will turn a violet to blue color.

3. Push and twist pipet tip onto tapered end of the syringe. Be certain to create an air tight-fit. Take the titration syringe and push the plunger completely into the syringe.

4. Insert tip into $\mathrm{HI}$ 3810-0 Titrant Solution (reagent 5) and pull the plunger out until the lower edge of the plunger seal is on the $0 \mathrm{~mL}$ mark of the syringe. The solution will stay in the pipet tip.

5. Place the syringe tip into the cap port of the plastic vessel and slowly add the titration solution, a drop at a time, swirling to mix after each drop. Continue adding titration solution until the solution in the plastic vessel changes from blue to colorless.

6. Read off the milliliters of titration solution from the syringe and multiply by 10 to obtain $\mathrm{mg} / \mathrm{L}$ (ppm) of dissolved oxygen. Record the value on the datasheet.

d. Nitrates ${ }^{8}:(C)$

1. Fill the glass cuvet with $10 \mathrm{~mL}$ of the sample, up to the mark.

2. Add 1 packet of powdered HI 3874-0 Nitrate Reagent to the vial.

3. Cap the vial, and then shake it strongly for 1 minute.

4. Wait 4 minutes for the color to develop.

5. Pour $5 \mathrm{~mL}$ of the solution into the plastic comparator tube.

6. Select the color on the color scale of the comparator tube that most closely matches the prepared sample. You will find it easier to make a determination if you hold the tube up to a white piece of paper.

7. Record the value on the datasheet.
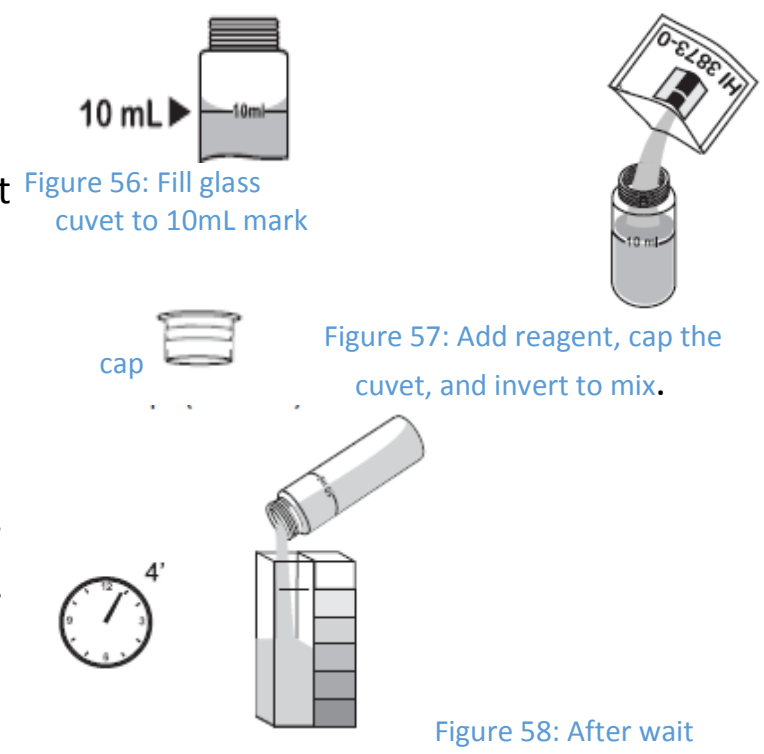

time elapses, pour solution into comparator cube.

e. Nitrites ${ }^{9}:(\mathrm{C})$

1. Fill the glass cuvet with $10 \mathrm{~mL}$ of the sample, up to the mark.

2. Add 1 packet of powdered HI 3873-0 Nitrite Reagent to the vial.

3. Cap the vial, and then gently invert it for 15 seconds.

4. Wait 6 minutes for the color to develop.

5. Pour $5 \mathrm{~mL}$ of the solution into the plastic comparator

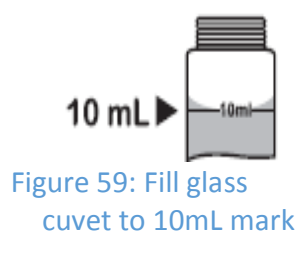

cuvet to $10 \mathrm{~mL}$ mar

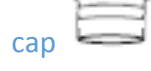

Figure 60: Add reagent, cap the cuvet, and invert to mix.

${ }_{9}^{8}$ Hanna Instruments HI3874

9 Hanna Instruments HI3873 
tube.

6. Select the color on the color scale of the comparator tube that most closely matches the prepared sample. You will find it easier to make a determination if you hold the tube up to a white piece of paper.

7. Record the value on the datasheet.

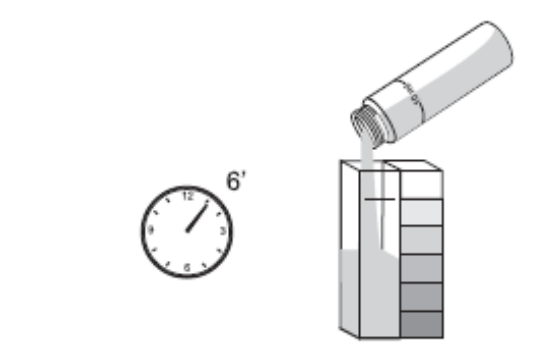

Figure 61: After wait time elapses, pour solution into comparator cube.

f. $\mathrm{pH}:(\mathrm{D})$

The HI98127 $\mathrm{pHep}^{\circledR} 4 \mathrm{pH} /$ Temperature Tester is used to collect $\mathrm{pH}$ data.

1.To turn the meter on and check the battery status: Press and hold the /MODE button until the LCD lights up. All the used segments on the LCD will be visible for 1 second (or as long as the button is pressed), followed by the percent indication of the remaining battery life (E.g. \% 100 BATT).

2. Taking measurements: Submerge the electrode in the solution (waterbody) to be tested. The measurements should be taken when the stability symbol $\square$ on the top left of the LCD disappears. The large number is the $\mathrm{pH}$ reading. (The smaller sized number shows the temperature of the sample.)

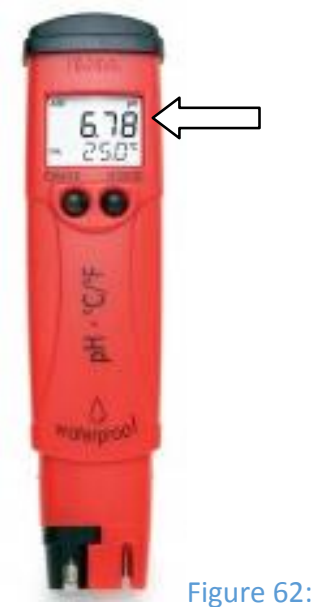

HI98127 pHep ${ }^{\circledR}$ pH / Temperature Tester 
g. Phosphates ${ }^{10}:(\mathrm{C})$

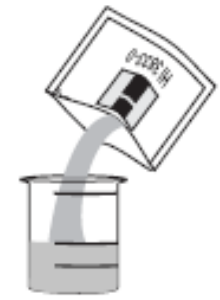

Figure 63: Pour reagent into

$10 \mathrm{~mL}$ of sampled

water

1. Rinse the plastic vial with sample water and discard the rinse water.

2. Fill the vial up to the $10 \mathrm{~mL}$ mark.

3. Add powdered reagent $\mathrm{HI} 3833$ to the sample water.

4. Add the plastic cap and then swirl to mix until the reagent solids are dissolved.

5. Wait 1 minute for the color to develop.

6. Pour the solution into the comparator cube.

7. Determine which color matches the solution in the cube and record the result as $\mathrm{mg} / \mathrm{L}(\mathrm{ppm})$ of phosphate $\left(\mathrm{PO}_{4}{ }^{3-}\right)$.

h. Salinity ${ }^{11}:(T)$

The salinity concentration $(\mathrm{g} / \mathrm{kg})$ is determined by titration method.

1. You will use separate pipet tips for sampling and titration.

2. Push and twist the first pipet tip onto tapered end of syringe to ensure an air-tight fit then push the plunger completely into the syringe. Insert tip into water sample and pull the plunger out until the lower edge of the plunger seal is on the $0 \mathrm{~mL}$ mark of the syringe.

3. Plunge the water sample into the small white vial.

4. Add 1 drop of Diphenylcarbazone indicator (reagent 1) and cap the vial. As you swirl to mix the solution will turn a violet color.

5. Remove the cap. While swirling the vial, add a drop of Nitric Acid (reagent 2) until the solution becomes yellow (usually one drop).

6. Replace the pipet tip on the titration syringe. Push plunger completely into the syringe. Insert tip into HI 3835-0 Reagent Titrant Solution and pull plunger out until the lower edge of the plunger seal is on the $0 \mathrm{~mL}$ mark of the syringe. The buffering solution will only fill the pipet tip.

7. Place syringe tip into the plastic vial and slowly add the titration solution drop by drop, swirling to mix after each drop.Continue adding titration solution until the solution in the vial changes from yellow to violet.

8. Read off the milliliters of titration solution from the syringe scale, and multiply by 40 to obtain salinity in $\mathrm{g} / \mathrm{kg}$ (ppt).

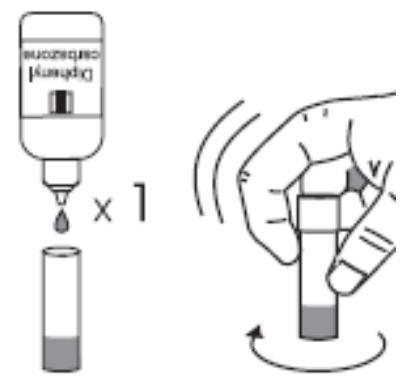

Figure 64: Add indicator and mix

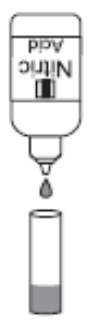

Figure 65: Add nitric acid.

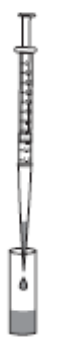

Figure 66: titrate into small vial

\section{i. Total Dissolved Solids: (D)}

TDS data are obtained using the HI98312 DiST ${ }^{\circledR} 6 \mathrm{EC} / \mathrm{TDS} /$ Temperature Tester. To turn the meter on and to check battery status using the button labeled 3 in diagram (figure 42). 


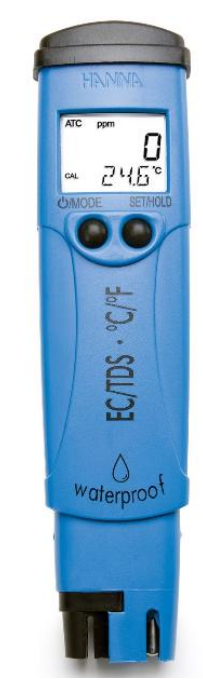

Figure 67: HI98312

DiST $^{\circledR} 6$

EC/TDS/Temperature

Tester
Press and hold the same button "/MODE" for 2-3 seconds. All the used segments on the LCD will be visible for a few seconds, followed by a percent indication of the remaining battery life (E.g. \% 100 BATT).

Taking measurements: Submerge the probe in the water.. Confirm that the unit is ppt in the LCD section - labeled 2 . Select the TDS reading mode with the SET/HOLD button (6) The measurements should be taken when the stability symbol $\square$ on the top left of the LCD disappears. The TDS value (automatically compensated for temperature) is shown on the primary (larger) LCD at the tops of the screen while the secondary (smaller, lower level) LCD shows the temperature of the sample (see figure 3 or 43).

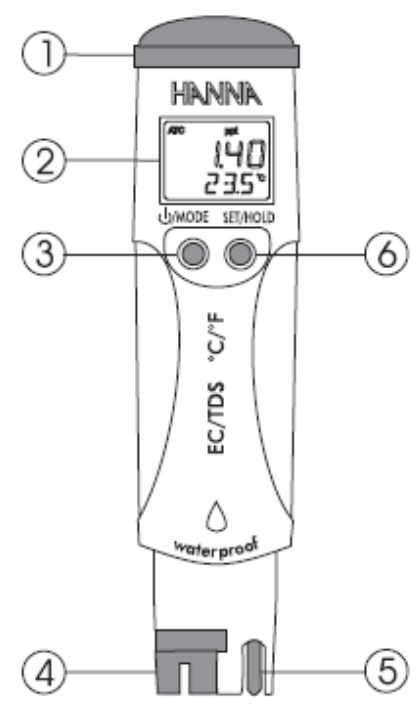

1. Battery compartment

2. Liquid Crystal Display (LCD)

3. ON/OFF/MODE button

4. HI $73311 \mathrm{EC} / \mathrm{TDS}$ probe

5. Temperature sensor

6. SET/HOLD button

Figure 68: Functional diagram of

HI98312

j. Water temperature: (D)

The measure of the heat or coolness of water can affect the amount of oxygen water can hold and the absorbability of chemicals by sediment and organisms.

Temperature data is gathered using the HI98127 $\mathrm{pHep}^{\circledR} 4 \mathrm{pH} /$ Temperature Tester. To turn the meter on and check the battery status: Press and hold the /MODE button until the LCD lights up. All the used segments on the LCD will be visible for 1 second (or as long as the button is pressed), followed by the percent indication of the remaining battery life (E.g. \% 100 BATT). Taking measurements: Submerge the electrode in the solution to be tested while stirring it gently. The measurements should be taken when the stability symbol

a on the top left of the LCD disappears. The secondary LCD shows the temperature of the sample.

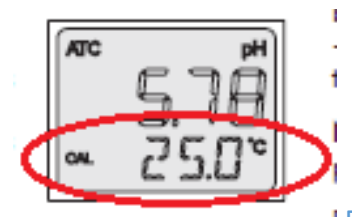

I Figure 69: Secondary LCD Provide the Temperature Reading

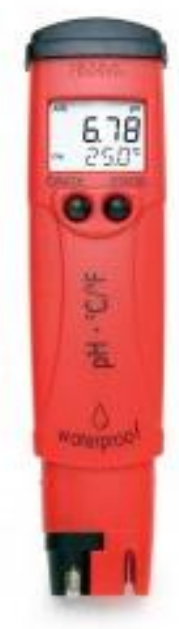

Figure 70: $\mathrm{HI} 98127 \mathrm{pHep}^{\circledR} 4$ $\mathrm{pH} /$ Temperature Tester 


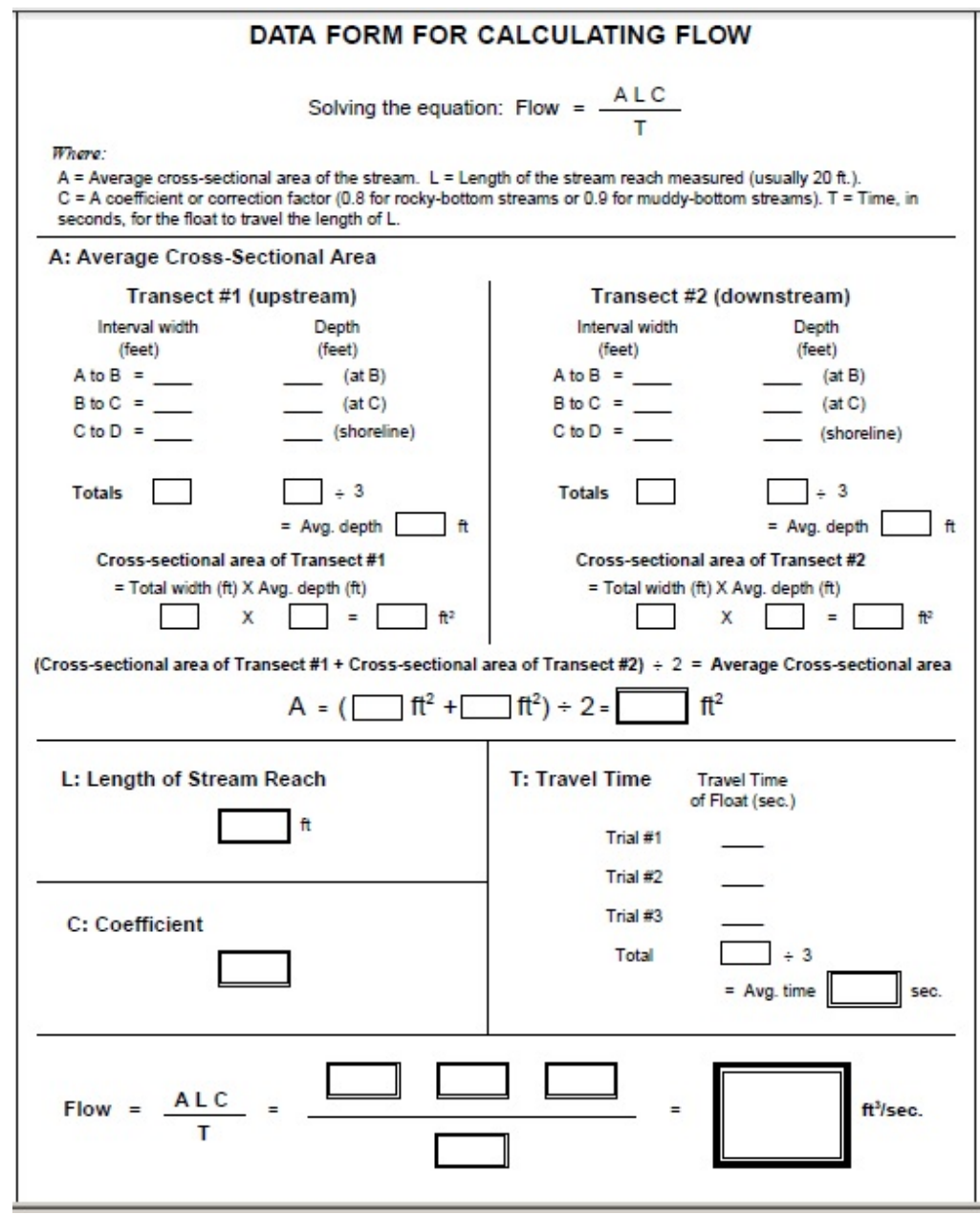

Cubic feet per second (cfs) flow rates are calculated by measuring the average cross-sectional area of the stream in feet/inches and the length of time it takes for a float to travel from one end of the measured area to the other.

Begin by noting whether the stream bed sediment is cobble/gravelly or is silty on the datasheet.

Next measure the width and depth of the stream. The width of the stream is measured at the site marker (flow end). It is also measured at a distance that is 20 feet upstream (flow start). At each end of this area three depth measurements are taken. One is taken at the eastern $1 / 3$ of the stream width, another at the center, and the third is taken at the western $1 / 3$ of the stream width. These measurements will be used to calculate the average cross-sectional area.

Lastly, measure the length of time it takes for a float to travel down the measured stream length on the west side, east side, and down the center using the floats, net, and timer.

\section{Invertebrates}

Invertebrate sampling is completed at each of the four the monitoring sites. Samples are collected in the stream and on the banks at the mean lower low water mark (MLLW) and at the wrack line or mean higher high water mark (MHHW). Kick nets are utilized for in-stream sampling of benthic invertebrates if the stream bed is cobbled. Otherwise glass bottles are used to collect in samples from the water column at locations with muck substrate. Pit traps were used for shoreline sample collection.

\section{a) Field Procedures}

\section{In-stream}

"Kick nets" Place the kick net in the stream with the metal frame on the streambed and the back of the net toward downstream. Hold it in place with your boot or with help of another volunteer. Scrape large cobble by had to clear invertebrates from these larger stones. Place the scrubbed stone outside of the net frame. Use the hand trowel, pushed into the cobble and pebbles about 2 inches, to stir vigorously for 1 minute. Empty the contents of the net into the specimen bin. Turn the net inside out, holding it over the bin, then rinse the remaining contents into the container. Gently swirl the bin to help settle the solid contents. Pour the water through the strainer, and then deposit the strained contents into the specimen bottle. This bottle should be labeled with the transit number and "stream." 
Grab samples Submerge the bottle upstream from where you are standing at the deepest part of the stream (thalwag). Turn the bottle away from the current and scoop in a downstream direction. Pour the contents of the sample bottle through the sieve. Add the sieved contents to the isopropyl alcohol storage container. This bottle should be labeled with the transit number and "stream."

Along the bank - Large plastic party cups (16 ounce) are used for the pit/ pitfall traps. Select five random locations along an $88 \mathrm{~m}$ transit that runs parallel to the streambed at the Mean Lower Low Water (MLLW). This process is repeated at Mean Higher High Water (MHHW) aka the wrack line. Pitfall traps are placed in this manner on each side of the creek. The pit traps are placed by digging into the sediment deeply enough for the lip of the cup to be flush with the surface. Add one drop of the clear dishwashing soap (odorless and phosphate free) to the cup, then pour in strained water to the first line above the cup's base (approximately $3 \mathrm{~cm}$ deep). Leave the cup in place for 1 hour. Upon return, pour the contents of the cup through the sieve. Add the sieved contents to the isopropyl alcohol storage container. This bottle should be labeled with the transit number and marked "pit."

\section{b) Lab Procedures}

Use of laboratory equipment is governed by the Area Manager of Olympic College's Science Lab. A brief information session will be held at the start of the session.

Samples are viewed from a single site at a time. Contents from the storage container will be poured into a shallow tray. Using long handled tweezers, gently place the sample onto a petri dish and place them under the microscope lens. Adjust accordingly for a clear view of the invertebrate. Use the invertebrate guide (key) to determine the species being viewed. Findings are recorded on the datasheet.

\section{E. Sediments}

\section{A. Composition}

Sediment size and composition affects the types of insects, invertebrates, and spawning fish using the area and in turn food supplies available to salmonids. To characterize the surface sediment of the shoreline near each monitoring site, quadrats measuring $0.5 \mathrm{~m}^{2}$, are placed along a transit that crosses the streambed every three meters. Photographs are taken at each placement. The photos assist in making a visual estimate of the percentage of cobble and fines present at the survey sites. Note the type and percentage of sediments on the datasheet. Surface sediments are classified by size, using visual estimations for stones and touch for fines. Classes used are

- cobble (>6 cm or $\sim 2 \mathrm{in})$,

- pebble ( $4 \mathrm{~mm}$ to $6 \mathrm{~cm}$ or $1 / 6^{\text {th }}$ to $\sim 2 \mathrm{in}$ )

- granule ( 2 to $4 \mathrm{~mm}$ or $1 / 12^{\text {th }}$ to $1 / 6^{\text {th }} \mathrm{in}$ ),

- sand ("gritty" up to $2 \mathrm{~mm}$ or $1 / 12^{\text {th }} \mathrm{in}$ ), and

- silt/clay (smooth between fingers). 


\section{B. Elevations}

Specialized equipment including a surveyor's sighting (optical) level and a stadia rod are used to document the shore and stream elevations of each site along an east to west transect. A $150 \mathrm{~m}$ or longer measuring reel is also required. Flags are helpful as placeholders. A minimum of two people per team are needed to accomplish this task. One person will operate the level ("Sighter"). Another will measure and move the stadia rod across the beach/shoreline ("Poster"). A third person, acting as a data recorder is helpful ("Recorder").

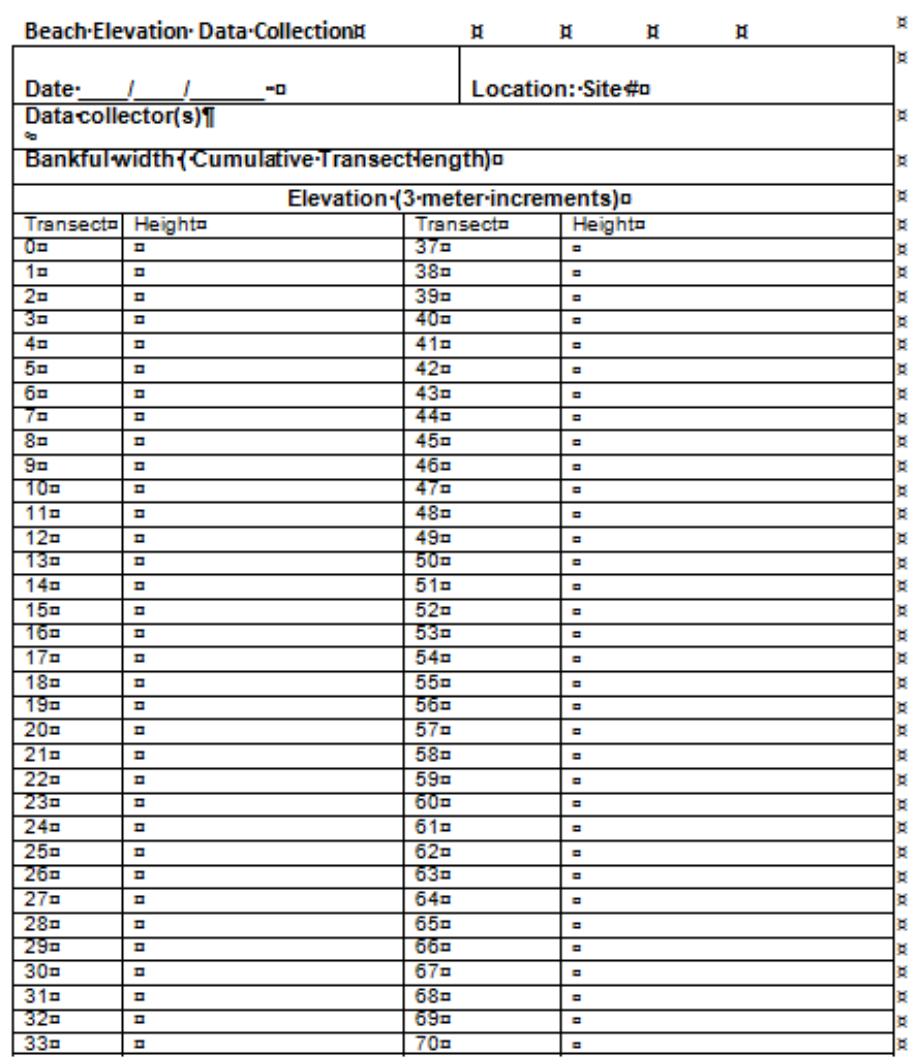

The level is set up at the pre-marked starting point on the eastern bank. The base is stabilized by locking the legs into place so that the plumb bob and built in level indicate the unit is leveled. The transit line is marked by extending the reel along the surface from the starting point to the stream edge in the direction of the pre-marked end point. The Poster returns to the starting point and measures three meters from the level for the first interval* and then sets the rod so that the Viewer can read the measurements on the face of it. The Sighter focuses the lens of the level and reads off the height on the rod that is in the cross hairs of the level. This value is recorded by either the Sighter or the Recorder. Once a thumbs up signal is given by the Sighter, the Poster moves another three meters and the process is repeated.

Once the streambed is reached another interval is measured. If streamflow is low, the reel may stay in place. Otherwise use a flag to mark the last sighting location on the shoreline as a point of reference and to keep the transit straight. Continue taking measurements until the end point of the transit is reached.

*At Site 4, the measurements are taken in one meter increments to improve the detail of the profile. 


\section{F. Vegetation}

Annual vegetation surveys are made to document species of plants along the shoreline line at each of the monitoring sites. An $88 \mathrm{~m}$ transit is run parallel to the stream and above MHHW (wrack line). Every $22 \mathrm{~m}$ place the PVC quadrat to record the plants present within the square. All plant types within the quadrat are recorded along with the percentage of the total vegetation cover each represents. If bare earth is within the quadrat, the percentage may not equal $100 \%$.

Indicate on the datasheet whether the plants are healthy or not. Place the appropriate tag near the square, then take a picture of the quadrat that clearly shows the plants and label.

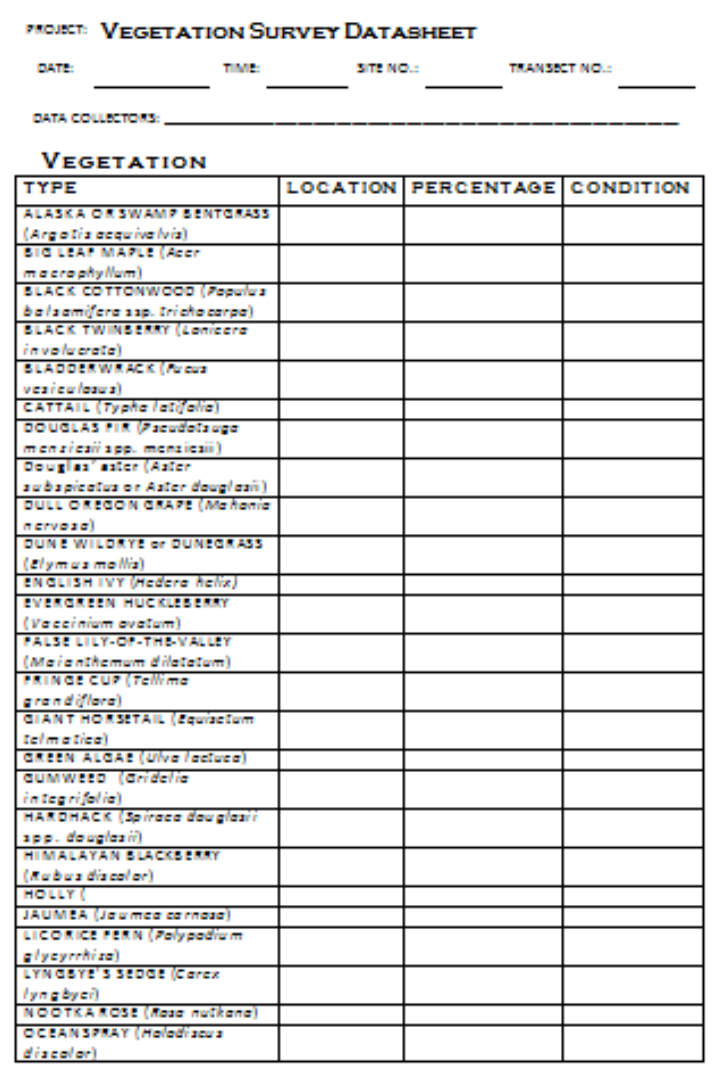

\section{G. Beach Seining}

At high tide, a 100 foot net is set approximately 50 feet offshore. The ends of the net remain on shore so that it can be hauled in manually by volunteers on the beach. The net is dragged in as quickly as possible while insuring the weights stay on the bottom of the inlet. This will allow capture of a greater number and variety of present species. Collected samples are taken from the net and placed into 5 gallon buckets filled with water from the inlet. Volunteers, assisted by experienced seiners and biologists use the provided trays to measure the length of captured fish from nose to the center of the tail. The type and length are provided to the data recorded. Place the measured fish into the wading pools to prevent duplicate counting and to allow viewing by participants. At the end of the count, samples are returned unharmed into nearshore waters.

\begin{tabular}{|c|c|c|c|c|c|c|c|c|}
\hline Species_Name & $\begin{array}{c}\text { Species_Total__ } \\
\text { Count }\end{array}$ & Sample_Date & Sample_Time & Air_Temp(C) & Water_Temp(C) & \begin{tabular}{|c|} 
Disolved_Oxygen \\
$(\mathrm{mg} / \mathrm{L})$
\end{tabular} & Salinity(ppt) & Secchi_Depth(tt) \\
\hline \multicolumn{9}{|l|}{ American Shad } \\
\hline \multicolumn{9}{|l|}{ Bay Goby } \\
\hline \multicolumn{9}{|l|}{ Bay Goby } \\
\hline \multicolumn{9}{|l|}{ Bay Pipefish } \\
\hline \multicolumn{9}{|l|}{ Chum Salmon } \\
\hline \multicolumn{9}{|l|}{ Coho Salmon } \\
\hline \multicolumn{9}{|l|}{ Pacific Herring } \\
\hline \multicolumn{9}{|l|}{$\begin{array}{l}\text { Pacific Snake } \\
\text { Prickleback }\end{array}$} \\
\hline \multicolumn{9}{|l|}{ Shiner Perch } \\
\hline \multicolumn{9}{|l|}{ Staghorn Sculpin } \\
\hline \multicolumn{9}{|l|}{ Starry Flounder } \\
\hline \multicolumn{9}{|l|}{ Surf Smelt } \\
\hline $\begin{array}{l}\text { Threespine } \\
\text { Stickleback }\end{array}$ & & & & & & & & \\
\hline
\end{tabular}


XIV. Appendix C - Kitsap Health Department Conventional WQM Data

Table 19: Kitsap Health Department reported values for conventional water quality parameters for CC01, a freshwater site north of the Clear Creek Estuary and DY27, a marine site south of the estuary from 2004-2015. Not all data are available for all years

\begin{tabular}{|c|c|c|c|c|c|}
\hline Station & Parameter & Year & \# of Samples & Samples Range & Meets WQS \\
\hline \multirow[t]{36}{*}{ CC01 } & \multirow[t]{12}{*}{$\mathrm{DO}$} & 2004 & 3 & $10.4-11.1 \mathrm{mg} / \mathrm{L}$ & Yes \\
\hline & & 2005 & 12 & $8.6-12.8 \mathrm{mg} / \mathrm{L}$ & Yes \\
\hline & & 2006 & 12 & $9.1-12.8 \mathrm{mg} / \mathrm{L}$ & Yes \\
\hline & & 2007 & 12 & $9.9-12.3 \mathrm{mg} / \mathrm{L}$ & Yes \\
\hline & & 2008 & 8 & $9.9-12.4 \mathrm{mg} / \mathrm{L}$ & Yes \\
\hline & & 2009 & N/A & $\mathrm{N} / \mathrm{A}$ & N/A \\
\hline & & 2010 & $\mathrm{~N} / \mathrm{A}$ & $\mathrm{N} / \mathrm{A}$ & $\mathrm{N} / \mathrm{A}$ \\
\hline & & 2011 & N/A & $\mathrm{N} / \mathrm{A}$ & N/A \\
\hline & & 2012 & N/A & N/A & N/A \\
\hline & & 2013 & $\mathrm{~N} / \mathrm{A}$ & $\mathrm{N} / \mathrm{A}$ & $\mathrm{N} / \mathrm{A}$ \\
\hline & & 2014 & $\mathrm{~N} / \mathrm{A}$ & $\mathrm{N} / \mathrm{A}$ & $\mathrm{N} / \mathrm{A}$ \\
\hline & & 2015 & $\mathrm{~N} / \mathrm{A}$ & $\mathrm{N} / \mathrm{A}$ & $\mathrm{N} / \mathrm{A}$ \\
\hline & \multirow[t]{12}{*}{$\mathrm{pH}$} & 2004 & 3 & $7.5-8.0$ & Yes \\
\hline & & 2005 & 12 & 7.6-8.3 & Yes \\
\hline & & 2006 & 12 & 7.3-8.3 & Yes \\
\hline & & 2007 & 12 & $7.6-8.1$ & Yes \\
\hline & & 2008 & 8 & 7.2-7.6 & Yes \\
\hline & & 2009 & $\mathrm{~N} / \mathrm{A}$ & $\mathrm{N} / \mathrm{A}$ & $\mathrm{N} / \mathrm{A}$ \\
\hline & & 2010 & $\mathrm{~N} / \mathrm{A}$ & $\mathrm{N} / \mathrm{A}$ & N/A \\
\hline & & 2011 & $\mathrm{~N} / \mathrm{A}$ & N/A & N/A \\
\hline & & 2012 & N/A & N/A & N/A \\
\hline & & 2013 & $\mathrm{~N} / \mathrm{A}$ & N/A & N/A \\
\hline & & 2014 & N/A & N/A & N/A \\
\hline & & 2015 & N/A & $\mathrm{N} / \mathrm{A}$ & N/A \\
\hline & \multirow[t]{12}{*}{ Temperature } & 2004 & 3 & $7.4-10.9^{\circ} \mathrm{C}$ & Yes \\
\hline & & 2005 & 12 & $3.4-12.8^{\circ} \mathrm{C}$ & Yes \\
\hline & & 2006 & 12 & $5.4-12.7^{\circ} \mathrm{C}$ & Yes \\
\hline & & 2007 & 12 & $4.7-13.9^{\circ} \mathrm{C}$ & Yes \\
\hline & & 2008 & 8 & $5.6-12.8^{\circ} \mathrm{C}$ & Yes \\
\hline & & 2009 & N/A & $\mathrm{N} / \mathrm{A}$ & N/A \\
\hline & & 2010 & $\mathrm{~N} / \mathrm{A}$ & $\mathrm{N} / \mathrm{A}$ & $\mathrm{N} / \mathrm{A}$ \\
\hline & & 2011 & $\mathrm{~N} / \mathrm{A}$ & N/A & N/A \\
\hline & & 2012 & N/A & N/A & N/A \\
\hline & & 2013 & N/A & N/A & N/A \\
\hline & & 2014 & N/A & N/A & $\mathrm{N} / \mathrm{A}$ \\
\hline & & 2015 & N/A & N/A & N/A \\
\hline
\end{tabular}

\begin{tabular}{|c|c|c|c|c|c|}
\hline Station & Parameter & Year & \# of Samples & Samples Range & Meets WQS \\
\hline \multirow[t]{44}{*}{ DY27 } & \multirow[t]{11}{*}{ DO } & 2005 & 3 & $6.3-14.8 \mathrm{mg} / \mathrm{L}$ & Yes \\
\hline & & 2006 & 1 & $7.9 \mathrm{mg} / \mathrm{L}$ & Yes \\
\hline & & 2007 & $\mathrm{~N} / \mathrm{A}$ & $\mathrm{N} / \mathrm{A}$ & $\mathrm{N} / \mathrm{A}$ \\
\hline & & 2008 & 4 & $8.4-12.8 \mathrm{mg} / \mathrm{L}$ & Yes \\
\hline & & 2009 & $\mathrm{~N} / \mathrm{A}$ & $\mathrm{N} / \mathrm{A}$ & $\mathrm{N} / \mathrm{A}$ \\
\hline & & 2010 & $\mathrm{~N} / \mathrm{A}$ & $\mathrm{N} / \mathrm{A}$ & $\mathrm{N} / \mathrm{A}$ \\
\hline & & 2011 & $\mathrm{~N} / \mathrm{A}$ & $\mathrm{N} / \mathrm{A}$ & $\mathrm{N} / \mathrm{A}$ \\
\hline & & 2012 & $\mathrm{~N} / \mathrm{A}$ & $\mathrm{N} / \mathrm{A}$ & $\mathrm{N} / \mathrm{A}$ \\
\hline & & 2013 & N/A & N/A & N/A \\
\hline & & 2014 & N/A & N/A & N/A \\
\hline & & 2015 & $\mathrm{~N} / \mathrm{A}$ & $\mathrm{N} / \mathrm{A}$ & N/A \\
\hline & \multirow[t]{11}{*}{$\mathrm{pH}$} & 2005 & 3 & $8-8.2$ & Yes \\
\hline & & 2006 & 2 & $8.2-8.6$ & Yes \\
\hline & & 2007 & N/A & N/A & N/A \\
\hline & & 2008 & $\mathrm{~N} / \mathrm{A}$ & $\mathrm{N} / \mathrm{A}$ & $\mathrm{N} / \mathrm{A}$ \\
\hline & & 2009 & $\mathrm{~N} / \mathrm{A}$ & $\mathrm{N} / \mathrm{A}$ & $\mathrm{N} / \mathrm{A}$ \\
\hline & & 2010 & 2 & $7.2-7.2$ & Yes \\
\hline & & 2011 & 12 & $7.2-8.1$ & Yes \\
\hline & & 2012 & 6 & $7.4-8.3$ & Yes \\
\hline & & 2013 & $\mathrm{~N} / \mathrm{A}$ & $\mathrm{N} / \mathrm{A}$ & $\mathrm{N} / \mathrm{A}$ \\
\hline & & 2014 & $\mathrm{~N} / \mathrm{A}$ & $\mathrm{N} / \mathrm{A}$ & $\mathrm{N} / \mathrm{A}$ \\
\hline & & 2015 & 8 & $7.4-8.25$ & Yes \\
\hline & \multirow[t]{11}{*}{ Salinity } & 2005 & 6 & $27.6-31.1$ & $\mathrm{~N} / \mathrm{A}$ \\
\hline & & 2006 & 6 & 9.8-28.9 & $\mathrm{N} / \mathrm{A}$ \\
\hline & & 2007 & 8 & $28.7-33.2$ & $\mathrm{~N} / \mathrm{A}$ \\
\hline & & 2008 & 10 & $26.5-28.9$ & $\mathrm{~N} / \mathrm{A}$ \\
\hline & & 2009 & 11 & $6.4-28.6$ & $\mathrm{~N} / \mathrm{A}$ \\
\hline & & 2010 & 11 & $16.8-28.2$ & N/A \\
\hline & & 2011 & 12 & $4.6-28.9$ & N/A \\
\hline & & 2012 & 12 & $13.9-27.4$ & N/A \\
\hline & & 2013 & 12 & $8.1-28.4$ & $\mathrm{~N} / \mathrm{A}$ \\
\hline & & 2014 & 12 & 8.1-28.9 & $\mathrm{N} / \mathrm{A}$ \\
\hline & & 2015 & 12 & $9.5-30.6$ & $\mathrm{~N} / \mathrm{A}$ \\
\hline & \multirow[t]{11}{*}{ Temperature } & 2005 & 6 & $8.2-18.8^{\circ} \mathrm{C}$ & Yes \\
\hline & & 2006 & 6 & $7.4-16.8^{\circ} \mathrm{C}$ & Yes \\
\hline & & 2007 & 6 & $7.9-18.4^{\circ} \mathrm{C}$ & Yes \\
\hline & & 2008 & 10 & $7.2-17.6^{\circ} \mathrm{C}$ & Yes \\
\hline & & 2009 & 11 & $6.7-24.6^{\circ} \mathrm{C}$ & No \\
\hline & & 2010 & 11 & $7.3-19.5^{\circ} \mathrm{C}$ & Yes \\
\hline & & 2011 & 12 & $6.1-17.4^{\circ} \mathrm{C}$ & Yes \\
\hline & & 2012 & 12 & $5.1-16.8^{\circ} \mathrm{C}$ & Yes \\
\hline & & 2013 & 12 & $7-19.5^{\circ} \mathrm{C}$ & Yes \\
\hline & & 2014 & 12 & $6.4-20.9^{\circ} \mathrm{C}$ & Yes \\
\hline & & 2015 & 12 & $8-20.6^{\circ} \mathrm{C}$ & Yes \\
\hline
\end{tabular}




\section{Appendix D - Tested Parameters without Washington State Water Quality Standards}

The mean, variance, and standard deviation were calculated for parameters with no WA WQS. Parameters were grouped by season and then by sampling site. These data include two measures of acidity, two alkalinity tests or more correctly, acid neutralizing capacity (ANC), were measured as calcium carbonate $\left(\mathrm{CaCO}_{3}\right)$ concentrations. Concentrations were calculated using titration. Carbon dioxide $\left(\mathrm{CO}_{2}\right)$ levels as carbonic acid neutralized by sodium hydroxide was also tested using titration. Colorimetric assays were conducted for $\mathrm{PO}_{4}$, $\mathrm{NH}_{3} / \mathrm{NH}_{4}, \mathrm{NO}_{2}, \mathrm{NO}_{3}$, $\mathrm{Cu}$ and $\mathrm{Zn}$. Conductivity (EC) and Total Dissolved Solids (TDS) levels were recorded using hand held digital probes. Salinity concentrations were determined using a mercuric nitrate titration methodology.

Methyl orange and phenolphthalein acidity concentrations indicate the presence of metals and strong acids respectively, in the water column. Only Phenolphthalein Acidity (Acidity) concentrations were detected. The zero values for methyl orange acidity are not shown in the results [table 1]. Winter samples at a mean of 2.43ppm displayed slightly higher concentrations of 'strong' acids compared to 1.99ppm of summer samples. Summer samples display larger standard deviations (SD) from the mean at 1.463 vs. 0.836 winter samples from all sites.

Phenolphthalein ANC was not detected in any of the samples. Variable low levels of Total ANC were recorded for both seasons at all sites. ANC concentrations had similar means in both seasonal groupings, but greater variability in summer seasons [table 2]. The winter mean was 3.989ppm (SD $=1.097)$ and the summer mean was 3.976ppm (SD = 1.381).

Table 20: Acidity results for the baseline monitoring period detected occasional low level of phenolphthalein acidity.

\begin{tabular}{|c|c|c|c|c|c|}
\hline SEASON & SITE & $\begin{array}{c}\text { MEAN } \\
\text { ACIDITY } \\
\text { (ppm) }\end{array}$ & $\begin{array}{c}\text { VAR } \\
\text { ACIDITY } \\
\text { (ppm) }\end{array}$ & $\begin{array}{c}\text { SD } \\
\text { ACIDITY } \\
\text { (ppm) }\end{array}$ & $\begin{array}{c}\text { Range } \\
\left(\mathrm{CaCO}_{3}\right. \\
\text { ppm) }\end{array}$ \\
\hline Winter & ALL & 2.430 & 0.699 & 0.836 & \multirow[t]{10}{*}{$0-100$} \\
\hline \multirow[t]{4}{*}{ Oct - May } & 1 & 2.675 & 0.416 & 0.645 & \\
\hline & 2 & 2.758 & 0.843 & 0.918 & \\
\hline & 3 & 2.488 & 0.651 & 0.807 & \\
\hline & 4 & 2.363 & 1.001 & 1.000 & \\
\hline Summer & ALL & 1.944 & 2.141 & 1.463 & \\
\hline \multirow[t]{4}{*}{ Jun-Sep } & 1 & 1.384 & 2.244 & 1.498 & \\
\hline & 2 & 1.316 & 2.120 & 1.456 & \\
\hline & 3 & 2.725 & 1.230 & 1.109 & \\
\hline & 4 & 2.354 & 2.197 & 1.480 & \\
\hline
\end{tabular}

\begin{tabular}{|c|c|c|c|c|c|}
\hline SEASON & SITE & $\begin{array}{l}\text { MEAN } \\
\text { ANC } \\
(p p m)\end{array}$ & $\begin{array}{c}\text { VAR ANC } \\
\text { (ppm) }\end{array}$ & $\begin{array}{l}\text { SD ANC } \\
\text { (ppm) }\end{array}$ & $\begin{array}{c}\text { Range } \\
\left(\mathrm{CaCO}_{3}\right. \\
\text { ppm) }\end{array}$ \\
\hline Winter & ALL & 3.989 & 1.204 & 1.097 & $0-100$ \\
\hline \multirow[t]{4}{*}{ Oct - May } & 1 & 4.140 & 0.246 & 0.496 & \\
\hline & 2 & 4.401 & 0.189 & 0.434 & \\
\hline & 3 & 4.231 & 0.192 & 0.438 & \\
\hline & 4 & 3.245 & 3.514 & 1.874 & \\
\hline Summer & ALL & 3.976 & 1.906 & 1.381 & \\
\hline \multirow[t]{4}{*}{ Jun-Sep } & 1 & 4.273 & 0.340 & 0.583 & \\
\hline & 2 & 3.649 & 2.595 & 1.611 & \\
\hline & 3 & 3.972 & 2.627 & 1.621 & \\
\hline & 4 & 4.001 & 2.657 & 1.630 & \\
\hline
\end{tabular}

$\mathrm{CO}_{2}$ as measured as carbonic acid via titrant analysis results show low levels. The mean value was higher in the winter months at $1.343 \mathrm{ppm}$ with low variance in the data (0.26) compared to $1.201 \mathrm{ppm}(0.538)$. [table 3]

Phosphates $\left(\mathrm{PO}_{4}\right)$ analysis indicates moderate levels of this nutrient compound [table 4]. Summer mean concentration at $2.078 \mathrm{ppm}$ was higher than winter at $1.259 \mathrm{ppm}$. Natural sources from erosion are limited, except as related to high levels of upstream development. Anecdotal evidence suggests an additional source may have been an upstream local business found to be using detergent with phosphates as a roof top moss control on their commercial building (personal communication, R. Scherdnik) 
Table 22: Carbon Dioxide results for the baseline monitoring period demonstrate occasional low level $\mathrm{CO} 2$ readings

\begin{tabular}{|c|c|c|c|c|c|}
\hline SEASON & SITE & $\begin{array}{c}\text { MEAN } \\
\mathrm{CO}_{2} \\
(\mathrm{ppm})\end{array}$ & $\begin{array}{c}\text { VAR } \mathrm{CO}_{2} \\
\text { (ppm) }\end{array}$ & $\begin{array}{l}\mathrm{SD} \mathrm{CO}_{2} \\
\text { (ppm) }\end{array}$ & $\begin{array}{c}\text { Range ( } \\
\mathrm{CO}_{2} \text { ppm) }\end{array}$ \\
\hline \multirow[t]{5}{*}{1} & ALL & 1.343 & 0.260 & 0.510 & \multirow{10}{*}{\begin{tabular}{|l|l|} 
& $0-10$ \\
& \\
& \\
& \\
& \\
& \\
&
\end{tabular}} \\
\hline & 1 & 1.303 & 0.470 & 0.689 & \\
\hline & 2 & 1.539 & 0.178 & 0.422 & \\
\hline & 3 & 1.122 & 0.107 & 0.328 & \\
\hline & 4 & 1.425 & 0.298 & 0.546 & \\
\hline \multirow[t]{5}{*}{2} & ALL & 1.201 & 0.538 & 0.733 & \\
\hline & 1 & 1.123 & 0.270 & 0.519 & \\
\hline & 2 & 1.193 & 0.511 & 0.714 & \\
\hline & 3 & 1.277 & 0.485 & 0.696 & \\
\hline & 4 & 1.209 & 1.103 & 1.050 & \\
\hline
\end{tabular}

Table 24: Nitrogen compounds results for the baseline monitoring period demonstrate limited detection of low levels of total ammonia only

\begin{tabular}{|c|c|c|c|c|c|}
\hline SEASON & SITE & $\begin{array}{c}\text { MEAN } \\
\mathrm{NH}_{3} / \mathrm{NH}_{4} \\
(\mathrm{ppm})\end{array}$ & $\begin{array}{c}\text { VAR } \\
\text { NH3/NH4 } \\
\text { (ppm) }\end{array}$ & $\begin{array}{l}\text { SD NH4 } \\
\text { (ppm) }\end{array}$ & $\begin{array}{c}\text { Range } \\
\left(\mathrm{NH}_{3}\right. \\
\mathrm{NH}_{4} \\
\mathrm{ppm})\end{array}$ \\
\hline \multirow[t]{5}{*}{1} & ALL & 0.332 & 0.100 & 0.316 & \multirow[t]{10}{*}{$0-2.5$} \\
\hline & 1 & 0.373 & 0.069 & 0.263 & \\
\hline & 2 & 0.546 & 0.188 & 0.434 & \\
\hline & 3 & 0.237 & 0.065 & 0.255 & \\
\hline & 4 & 0.202 & 0.047 & 0.217 & \\
\hline \multirow[t]{5}{*}{2} & ALL & 0.195 & 0.039 & 0.197 & \\
\hline & 1 & 0.141 & 0.230 & 0.181 & \\
\hline & 2 & 0.289 & 0.078 & 0.279 & \\
\hline & 3 & 0.200 & 0.025 & 0.157 & \\
\hline & 4 & 0.149 & 0.214 & 0.146 & \\
\hline
\end{tabular}

Table 23: Phosphates results for the baseline monitoring period demonstrate occasional low level $\mathrm{PO} 4$ readings on

\begin{tabular}{|c|c|c|c|c|}
\hline SEASON & SITE & $\begin{array}{l}\text { MEAN } \\
\mathrm{PO}_{4(\mathrm{ppm})}\end{array}$ & $\begin{array}{c}\mathrm{SD} \mathrm{PO}_{4} \\
\text { (ppm) }\end{array}$ & WA WQS \\
\hline \multirow[t]{5}{*}{1} & ALL & 1.259 & 1.714 & Applicable \\
\hline & 1 & 0.344 & 0.694 & to \\
\hline & 2 & 0.194 & 0.216 & Lake \\
\hline & 3 & 1.972 & 1.962 & systems \\
\hline & 4 & 2.306 & 2.007 & only \\
\hline \multirow[t]{5}{*}{2} & ALL & 2.078 & 1.930 & Test \\
\hline & 1 & 2.750 & 2.035 & range \\
\hline & 2 & 1.969 & 1.939 & \multirow{3}{*}{ 1-5ppm } \\
\hline & 3 & 1.188 & 1.792 & \\
\hline & 4 & 2.406 & 1.955 & \\
\hline
\end{tabular}

The colorimetric assays completed for three nitrogen based compounds yielded low or null concentrations. Only ammonia $\left(\mathrm{NH}_{3} / \mathrm{NH}_{4}\right)$ data are displayed in the results table as any nitrites and nitrites $\left(\mathrm{NO}_{2} \& \mathrm{NO}_{3}\right)$ in the water column at the time of sampling were below detection limits of the reagents [table 5]. Detected amounts of $\left(\mathrm{NH}_{3} / \mathrm{NH}_{4}\right)$ were low and especially so during summer sampling perhaps due to greater uptake of nitrogen based compounds by biota during the growing season. Higher concentrations and variances occur at site 2 which arguably provides the least stable conditions for aquatic life due to upstream nutrient restriction and greater erosive forces from marine waters.

Increased levels of anthropogenically sourced nutrients may lead to decreased dissolved oxygen. All tests of dissolved metals resulted in no values above our detection limits. However, heavy metals such as copper or zinc formerly adsorbing to sediment may be detected in the water column due to incomplete bio-filtration from Filtera type bioremediation devises planned for the new bridge in the future. The dissolved metals may interfere with predator avoidance in juvenile salmon or navigation in adult salmon returning to spawn.

Data were also collected for physical components that can impact chemistry such as conductivity (EC) [table 6] and total dissolved solids (TDS) [table 7]. Both parameters are influenced by salinity levels and vary with diurnal activity as well as precipitation. Conductance gives a good idea of the amount of dissolved material in the water which can affect the suitability of water for beneficial uses. 
Table 25:. Conductivity. High variance

\begin{tabular}{|c|c|c|c|r|r|r|}
\hline SEASON & SITE & $\begin{array}{c}\text { MEAN } \\
(\mu \mathrm{S} / \mathrm{cm})\end{array}$ & $\begin{array}{c}\text { VAR EC } \\
(\mu \mathrm{S} / \mathrm{cm})\end{array}$ & $\begin{array}{c}\text { SD EC } \\
(\mu \mathrm{s} / \mathrm{cm})\end{array}$ & $\begin{array}{c}\text { FREQ } \\
\text { LOW } \\
\text { TIDE }\end{array}$ & $\begin{array}{c}\text { FREQ } \\
\text { HIGH } \\
\text { TIDE }\end{array}$ \\
\hline 1 & ALL & 6.352 & 3.420 & 1.850 & & \\
\hline & 1 & 8.007 & 2.804 & 1.675 & 6 & 2 \\
\hline & 2 & 7.100 & 4.259 & 2.064 & 6 & 2 \\
\hline & 3 & 5.287 & 0.954 & 0.977 & 8 & 1 \\
\hline & 4 & 5.281 & 1.122 & 1.060 & 8 & 1 \\
\hline & ALL & 6.509 & 4.666 & 2.160 & & \\
\hline & 1 & 6.978 & 9.520 & 3.085 & 6 & 2 \\
\hline & 2 & 6.644 & 8.751 & 2.958 & 6 & 2 \\
\hline & 3 & 6.548 & 1.293 & 1.137 & 5 & 3 \\
\hline
\end{tabular}

Table 26: Total Dissolved solids monitoring results for the baseline period predictably show greater ionic activity in more marine waters.

\begin{tabular}{|c|c|c|c|c|c|c|}
\hline SEASON & SITE & $\begin{array}{c}\text { MEAN TDS } \\
\text { (ppt) }\end{array}$ & $\begin{array}{l}\text { VAR TDS } \\
\text { (ppt) }\end{array}$ & $\begin{array}{l}\text { SD TDS } \\
\text { (ppt) }\end{array}$ & $\begin{array}{l}\text { FREQ } \\
\text { LOW } \\
\text { TIDE }\end{array}$ & $\begin{array}{c}\text { FREQ } \\
\text { HIGH } \\
\text { TIDE }\end{array}$ \\
\hline \multirow[t]{5}{*}{1} & ALL & 5.579 & 3.632 & 1.910 & & \\
\hline & 1 & 7.315 & 2.807 & 1.678 & 6 & 2 \\
\hline & 2 & 6.399 & 4.266 & 2.065 & 6 & 2 \\
\hline & 3 & 4.460 & 0.734 & 0.857 & 8 & 1 \\
\hline & 4 & 4.425 & 1.464 & 1.210 & 8 & 1 \\
\hline \multirow[t]{5}{*}{2} & ALL & 5.813 & 3.928 & 1.982 & & \\
\hline & 1 & 6.360 & 8.196 & 2.863 & 6 & 2 \\
\hline & 2 & 6.045 & 7.518 & 7.420 & 6 & 2 \\
\hline & 3 & 5.650 & 0.465 & 0.682 & 5 & 3 \\
\hline & 4 & 5.199 & 0.350 & 0.592 & 4 & 4 \\
\hline
\end{tabular}




\section{Appendix E - 2015 Vegetation Survey}

Vegetation composition was documented along the shoreline at each of the four monitoring site. Findings are displayed in total predominance rank order in the tables below along with the percentage found on the eastern bank and the western banks. Invasive species are presented in red text. At Site 1 and Site 2 saltwort (Salicornia virginica) was the most abundant species $(72.5 \%$ and $43.8 \%$, respectively). This species is generally located along salt marshes and shorelines without heavy wave action. The predominate species at Site 3 and Site 4 was Lyngbye's sedge (Carex lyngbyei), a common tidal marsh/ mudflat plant (58.8\% and $31.3 \%$, respectively). Sites 2 and 3 may experience changes in vegetation composition with the removal of the embankment.

Table 27: Monitoring results at Site 1, most southerly the in Clear Creek Estuary

\begin{tabular}{|lrrr|}
\hline SITE 1 & EAST & WEST & TOTAL \\
\hline $\begin{array}{l}\text { virginica) } \\
\square \text { GUMWEED (Gridelia integrifolia) }\end{array}$ & $57.5 \%$ & $15.0 \%$ & $72.5 \%$ \\
$\square$ SILVER BURWEED (Ambrosia chamissonis) & $15.0 \%$ & $3.8 \%$ & $18.8 \%$ \\
$\square$ THREAD ALGAE (Enteromorpha flexuosa) & $7.5 \%$ & $6.8 \%$ & $14.3 \%$ \\
$\square$ GREEN LETTUCE ALGAE (Ulva lactuca) & $6.5 \%$ & $0.0 \%$ & $6.5 \%$ \\
$\square$ LYNGBYE'S SEDGE (Carex lyngbyei) & $2.5 \%$ & $3.8 \%$ & $6.3 \%$ \\
$\square$ HIMALAYAN BLACKBERRY (Rubus discolor) & $1.3 \%$ & $5.0 \%$ & $6.3 \%$ \\
$\square$ RED GOOSEFOOT or COW SPINACH (Chenopodium rubrum) & $1.3 \%$ & $3.8 \%$ & $5.0 \%$ \\
$\square$ RED ALGAE (Rhodymenia palmate) & $2.5 \%$ & $1.3 \%$ & $3.8 \%$ \\
$\square$ JAUMEA (Jaumea carnosa) & $1.5 \%$ & $1.3 \%$ & $2.8 \%$ \\
$\square$ SEASIDE PLAINTAIN (Plantago maritime ssp. juncoides) & $2.5 \%$ & $0.0 \%$ & $2.5 \%$ \\
$\square$ SALTMARSH GRASS (Distichlis spicata) & $0.0 \%$ & $1.8 \%$ & $1.8 \%$ \\
$\square$ BLADDERWRACK (Fucus vesiculosus) & $0.0 \%$ & $1.5 \%$ & $1.5 \%$ \\
$\square$ BEACH PEA (Lathyrus maritimus) & $1.3 \%$ & $0.0 \%$ & $1.3 \%$ \\
$\square$ SILVERWEED (Potentilla anserine ssp. pacifica) & $0.0 \%$ & $0.8 \%$ & $0.8 \%$ \\
\hline
\end{tabular}

Table 28: Monitoring results at Site 2. This location is closest to the Bucklin Hill Bridge land berm.

\begin{tabular}{|c|c|c|c|}
\hline SITE 2 & EAST & WEST & TOTAL \\
\hline $\begin{array}{l}\square \text { SALTWORT Perennial saltwort or pickleweed (Salicornia } \\
\text { virginica) }\end{array}$ & $6.3 \%$ & $37.5 \%$ & $43.8 \%$ \\
\hline$\square$ SILVERWEED (Potentilla anserine ssp. pacifica) & $14.3 \%$ & $0.0 \%$ & $14.3 \%$ \\
\hline$\square$ GUMWEED (Gridelia integrifolia) & $0.0 \%$ & $12.5 \%$ & $12.5 \%$ \\
\hline$\square$ SILVER BURWEED (Ambrosia chamissonis) & $0.0 \%$ & $12.5 \%$ & $12.5 \%$ \\
\hline$\square$ RED GOOSEFOOT or COW SPINACH (Chenopodium rubrum) & $8.0 \%$ & $0.0 \%$ & $8.0 \%$ \\
\hline$\square$ HIMALAYAN BLACKBERRY (Rubus discolor) & $2.5 \%$ & $2.5 \%$ & $5.0 \%$ \\
\hline$\square$ LYNGBYE'S SEDGE (Carex lyngbyei) & $5.0 \%$ & $0.0 \%$ & $5.0 \%$ \\
\hline$\square$ DOUGLAS'S ASTER (Aster subspicatus or Aster douglasii) & $0.0 \%$ & $2.5 \%$ & $2.5 \%$ \\
\hline$\square$ DUNE WILDRYE or DUNEGRASS (Elymus mollis) & $2.5 \%$ & $0.0 \%$ & $2.5 \%$ \\
\hline$\square$ GREEN LETTUCE ALGAE (Ulva lactuca) & $0.0 \%$ & $2.5 \%$ & $2.5 \%$ \\
\hline$\square$ THREAD ALGAE (Enteromorpha flexuosa) & $0.0 \%$ & $2.5 \%$ & $2.5 \%$ \\
\hline 口] TRAILING BLACKBERRY (Rubus ursinus) & $2.5 \%$ & $0.0 \%$ & $2.5 \%$ \\
\hline$\square$ GIANT HORSETAIL (Equisetum telmatiea) & $1.8 \%$ & $0.0 \%$ & $1.8 \%$ \\
\hline $\begin{array}{l}\square \text { BELLADONA or EUROPEAN BITTERSWEET (Solanum } \\
\text { dolcamara) }\end{array}$ & $1.3 \%$ & $0.0 \%$ & $1.3 \%$ \\
\hline$\square$ GIANT HOGWEED (Heracleum mantegazzianum) & $1.3 \%$ & $0.0 \%$ & $1.3 \%$ \\
\hline$\square$ REED CANARYGRASS (Phalaris arundinacea) & $1.3 \%$ & $0.0 \%$ & $1.3 \%$ \\
\hline$\square$ SEASIDE PLAINTAIN (Plantago maritime ssp. juncoides) & $1.3 \%$ & $0.0 \%$ & $1.3 \%$ \\
\hline$\square$ SITKA WILLOW (Salix stichensis) & $0.8 \%$ & $0.0 \%$ & $0.8 \%$ \\
\hline$\square$ TANSY (Tanacetum vulgare) & $0.8 \%$ & $0.0 \%$ & $0.8 \%$ \\
\hline$\square$ WESTERN DOCK (Rumex occidentalis) & $0.5 \%$ & $0.0 \%$ & $0.5 \%$ \\
\hline
\end{tabular}


Table 29: Monitoring results at Site 3, located north and west of the Bucklin Hill Bridge embankment the in Clear Creek Estuary.

\begin{tabular}{|c|c|c|c|}
\hline SITE 3 & EAST & WEST & TOTAL \\
\hline$\square$ LYNGBYE'S SEDGE (Carex lyngbyei) & $0.0 \%$ & $58.8 \%$ & $58.8 \%$ \\
\hline$\square$ ENGLISH IVY (Hedera helix) & $23.8 \%$ & $0.0 \%$ & $23.8 \%$ \\
\hline$\square$ COMMON SNOWBERRY or WAXBERRY (Sympjoricarpos albus) & $11.3 \%$ & $0.0 \%$ & $11.3 \%$ \\
\hline$\square$ NOOTKA ROSE (Rosa nutkana) & $7.5 \%$ & $0.0 \%$ & $7.5 \%$ \\
\hline$\square$ RED ALDER (Alnus rubra) & $7.5 \%$ & $0.0 \%$ & $7.5 \%$ \\
\hline$\square$ SITKA WILLOW (Salix stichensis) & $0.0 \%$ & $7.5 \%$ & $7.5 \%$ \\
\hline$\square$ SALTMARSH GRASS (Distichlis spicata) & $0.0 \%$ & $6.3 \%$ & $6.3 \%$ \\
\hline$\square$ OCEANSPRAY (Holodiscus discolor) & $0.0 \%$ & $5.5 \%$ & $5.5 \%$ \\
\hline$\square$ DOUGLAS FIR (Pseudotsuga menziesii spp. menziesii) & $3.8 \%$ & $0.0 \%$ & $3.8 \%$ \\
\hline$\square$ HIMALAYAN BLACKBERRY (Rubus discolor) & $3.8 \%$ & $0.0 \%$ & $3.8 \%$ \\
\hline $\begin{array}{l}\square \text { BELLADONA or EUROPEAN BITTERSWEET (Solanum } \\
\text { dolcamara) }\end{array}$ & $2.5 \%$ & $0.0 \%$ & $2.5 \%$ \\
\hline$\square$ BLACK COTTONWOOD (Populus balsamifera ssp. trichocarpa) & $1.3 \%$ & $1.3 \%$ & $2.5 \%$ \\
\hline$\square$ FALSE LILY-OF-THE-VALLEY (Maianthemum dilatatum) & $0.0 \%$ & $2.5 \%$ & $2.5 \%$ \\
\hline$\square$ REED CANARYGRASS (Phalaris arundinacea) & $2.5 \%$ & $0.0 \%$ & $2.5 \%$ \\
\hline$\square$ TALL OREGON GRAPE (Mahonia aquifolium) & $2.5 \%$ & $0.0 \%$ & $2.5 \%$ \\
\hline$\square$ WESTERN DOCK (Rumex occidentalis) & $2.5 \%$ & $0.0 \%$ & $2.5 \%$ \\
\hline$\square$ WESTERN RED CEDAR (Thuja plicata) & $2.5 \%$ & $0.0 \%$ & $2.5 \%$ \\
\hline$\square$ SWORD FERN (Polystichum munitum) & $2.3 \%$ & $0.0 \%$ & $2.3 \%$ \\
\hline$\square$ DOUGLAS'S ASTER (Aster subspicatus or Aster douglasii) & $0.0 \%$ & $1.3 \%$ & $1.3 \%$ \\
\hline$\square$ SWEET GALE (Myrica gale) & $0.0 \%$ & $0.8 \%$ & $0.8 \%$ \\
\hline$\square$ BEAKED HAZELNUT (Corylus cornuta var. californica) & $0.5 \%$ & $0.0 \%$ & $0.5 \%$ \\
\hline$\square$ OSO BERRY (Oemleria cerasiformis) & $0.5 \%$ & $0.0 \%$ & $0.5 \%$ \\
\hline$\square$ RED-FLOWERING CURRENT (Ribes sanguineum) & $0.5 \%$ & $0.0 \%$ & $0.5 \%$ \\
\hline$\square$ SEASIDE ARROWGRASS (Triglochin maritimum) & $0.0 \%$ & $0.5 \%$ & $0.5 \%$ \\
\hline$\square$ TRAILING BLACKBERRY (Rubus ursinus) & $0.5 \%$ & $0.0 \%$ & $0.5 \%$ \\
\hline
\end{tabular}

Table 30: Monitoring results at Site 4, most northern location in the in Clear Creek Estuary

\begin{tabular}{|c|c|c|c|}
\hline SITE 4 & EAST & WEST & TOTAL \\
\hline$\square$ LYNGBYE'S SEDGE (Carex lyngbyei) & $31.3 \%$ & $0.0 \%$ & $31.3 \%$ \\
\hline$\square$ SALTMARSH GRASS (Distichlis spicata) & $27.5 \%$ & $0.0 \%$ & $27.5 \%$ \\
\hline$\square$ RED GOOSEFOOT or COW SPINACH (Chenopodium rubrum) & $16.3 \%$ & $0.0 \%$ & $16.3 \%$ \\
\hline$\square$ DOUGLAS FIR (Pseudotsuga menziesii spp. menziesii) & $0.0 \%$ & $12.5 \%$ & $12.5 \%$ \\
\hline$\square$ NOOTKA ROSE (Rosa nutkana) & $6.3 \%$ & $3.8 \%$ & $10.0 \%$ \\
\hline ? $\square$ TRAILING BLACKBERRY (Rubus ursinus) & $0.0 \%$ & $10.0 \%$ & $10.0 \%$ \\
\hline 물 DULL OREGON GRAPE (Mahonia nervosa) & $0.0 \%$ & $7.5 \%$ & $7.5 \%$ \\
\hline$\square$ SILVERWEED (Potentilla anserine ssp. pacifica) & $6.3 \%$ & $0.0 \%$ & $6.3 \%$ \\
\hline$\square$ YELLOW-FLAG IRIS (Iris pseudoacorus) & $6.3 \%$ & $0.0 \%$ & $6.3 \%$ \\
\hline$\square$ HIMALAYAN BLACKBERRY (Rubus discolor) & $4.3 \%$ & $1.3 \%$ & $5.5 \%$ \\
\hline$\square$ SALAL (Gaultheria shallon) & $0.0 \%$ & $5.0 \%$ & $5.0 \%$ \\
\hline$\square$ BEAKED HAZELNUT (Corylus cornuta var. californica) & $0.0 \%$ & $2.5 \%$ & $2.5 \%$ \\
\hline$\square$ BRACKEN FERN (Pteridium aquilnum) & $0.0 \%$ & $2.5 \%$ & $2.5 \%$ \\
\hline$\square$ ENGLISH PLANTAIN or BUCKHORN (Plantago lanceolata) & $0.0 \%$ & $2.5 \%$ & $2.5 \%$ \\
\hline$\square$ FALSE LILY-OF-THE-VALLEY (Maianthemum dilatatum) & $0.0 \%$ & $2.5 \%$ & $2.5 \%$ \\
\hline$\square$ SEASIDE ARROWGRASS (Triglochin maritimum) & $2.0 \%$ & $0.0 \%$ & $2.0 \%$ \\
\hline$\square$ DOUGLAS'S ASTER (Aster subspicatus or Aster douglasii) & $1.3 \%$ & $0.0 \%$ & $1.3 \%$ \\
\hline$\square$ EVERGREEN HUCKLEBERRY (Vaccinium ovatum) & $0.0 \%$ & $1.3 \%$ & $1.3 \%$ \\
\hline
\end{tabular}




\begin{tabular}{|lcrr|}
\hline SITE 4 CONt & EAST & WEST & TOTAL \\
$\square$ PACIFIC NINE BARK (Physocarpus capitatus) & $0.0 \%$ & $1.3 \%$ & $1.3 \%$ \\
$\square$ REED CANARYGRASS (Phalaris arundinacea) & $0.0 \%$ & $1.3 \%$ & $1.3 \%$ \\
$\square$ BELLADONA or EUROPEAN BITTERSWEET (Solanum dolcamara) & $0.8 \%$ & $0.0 \%$ & $0.8 \%$ \\
$\square$ WESTERN DOCK (Rumex occidentalis) & $0.5 \%$ & $0.0 \%$ & $0.5 \%$ \\
$\square$ DUNE WILDRYE or DUNEGRASS (Elymus mollis) & $0.0 \%$ & $0.0 \%$ & $0.0 \%$ \\
$\square$ GIANT HORSETAIL (Equisetum telmatiea) & $0.0 \%$ & $0.0 \%$ & $0.0 \%$ \\
$\square$ OCEANSPRAY (Holodiscus discolor) & $0.0 \%$ & $0.0 \%$ & $0.0 \%$ \\
$\square$ SITKA WILLOW (Salix stichensis) & $0.0 \%$ & $0.0 \%$ & $0.0 \%$ \\
$\square$ HOLLY (Ilex aquifolium) & $0.0 \%$ & $0.0 \%$ & $0.0 \%$ \\
\hline
\end{tabular}


XVII. Appendix F - Water Quality Standards for Metals in Surface Waters

\begin{tabular}{|c|c|c|c|c|c|c|c|}
\hline \multirow[b]{2}{*}{ Compound/Chemical } & \multirow[b]{2}{*}{ Category } & \multicolumn{2}{|c|}{$\begin{array}{c}\stackrel{\text { Aquatic Life }}{\text { Criteria-Freshwater }} \\
\underline{\underline{y}}\end{array}$} & \multicolumn{2}{|c|}{$\frac{\text { Aquatic Life Criteria - }}{\underline{\text { Marine Water }}}$} & \multicolumn{2}{|c|}{$\frac{\text { Human Health Criteria }}{\underline{\text { for Consumption of: }}}$} \\
\hline & & Acute & Chronic & Acute & $\underline{\text { Chronic }}$ & $\frac{\text { Water \& }}{\text { Organisms }}$ & $\frac{\text { Organisms }}{\underline{\text { Only }}}$ \\
\hline \multicolumn{8}{|l|}{ Metals: } \\
\hline$\underline{\text { Copper }}$ & $\begin{array}{l}\text { Metals, cyanide. } \\
\text { and total phenols }\end{array}$ & $(0, c, d d)$ & (p,d,dd) & $\left(\frac{4.8}{(, 11, d d)}\right.$ & $(\mathrm{d}, 11, \mathrm{dd})$ & $\frac{1,300}{(\mathrm{D})}$ & \\
\hline$\underline{\text { Zinc }}$ & $\begin{array}{l}\text { Metals, cyanide, } \\
\text { and total phenols }\end{array}$ & (aa,c,dd) & (bb,d,dd) & $\frac{90,0}{(\mathrm{c}, 11, \mathrm{dd})}$ & $\frac{81,0}{(\mathrm{~d}, 11, \mathrm{dd})}$ & $\underline{2,300}$ & $\underline{2.900}$ \\
\hline
\end{tabular}

c. A 1-hour average concentration not to be exceeded more than once every three years on the average.

d. A 4-day average concentration not to be exceeded more than once every three years on the average.

o. $\leq(0.960)\left(\mathrm{e}^{(0.9422[\ln (\text { hardness })]-1.464)}\right)$

p. $\leq(0.960)\left(\mathrm{e}^{(0.8545[\ln (\text { hardness })]-1.465)}\right)$

aa. $\leq(0.978)\left(\mathrm{e}^{(0.8473[\ln (\text { hardness })]+0.8604)}\right)$

bb. $\leq(0.986)\left(\mathrm{e}^{(0.8473[\ln (\text { hardness })]+0.7614)}\right)$

dd. These ambient criteria in the table are for the dissolved fraction. The cyanide criteria are based on the weak acid dissociable method. The metals criteria may not be used to calculate total recoverable effluent limits unless the seasonal partitioning of the dissolved to total metals in the ambient water are known. When this information is absent, these metals criteria shall be applied as total recoverable values, determined by back-calculation, using the conversion factors incorporated in the criterion equations. Metals criteria may be adjusted on a site-specific basis when data are made available to the department clearly demonstrating the effective use of the water effects ratio approach established by USEPA, as generally guided by the procedures in USEPA Water Quality Standards Handbook, December 1983, as supplemented or replaced by USEPA or ecology. Information which is used to develop effluent limits based on applying metals partitioning studies or the water effects ratio approach shall be identified in the permit fact sheet developed pursuant to WAC 173-220-060 or 173-226-110, as appropriate, and shall be made available for the public comment period required pursuant to WAC 173-220-050 or 173-226-130(3), as appropriate. Ecology has developed supplemental guidance for conducting water effect ratio studies.

11. Marine conversion factors (CF) which were used for calculating dissolved metals concentrations are given below. Conversion factors are applicable to both acute and chronic criteria for all metals except mercury. The CF for mercury was applied to the acute criterion only and is not applicable to the chronic criterion. Conversion factors are already incorporated into the criteria in the table. Dissolved criterion = criterion $\mathrm{x} C \mathrm{CF}$

Figure 71: Adapted from WAC 173-201A-240 Toxic substances. 